WALTER JOSÉ CELESTE DE OLIVEIRA

\title{
A JUSTIFICAÇÃO RACIONAL DA AUTORIDADE À LUZ DO PARADIGMA DA MODERNIDADE
}

\author{
DisSERTAÇÃo - MESTRAdO \\ Orientador: Prof. Juliano Souza de Albuquerque maranhão
}

FACULDADE DE DIREITO DA USP

SÃO PAULO

2013 


\title{
WALTER JOSÉ CELESTE DE OLIVEIRA
}

\section{A JUSTIFICAÇÃO RACIONAL DA AUTORIDADE À LUZ DO PARADIGMA DA MODERNIDADE}

\author{
DiSSERTAÇÃO - MESTRADO \\ Orientador: Prof. Juliano de Souza Albuquerque Maranhão \\ Dissertação apresentada como exigência parcial à \\ obtenção do título de Mestre em Direito, no âmbito do \\ Programa de Pós-Graduação da Faculdade de Direito \\ da Universidade de São Paulo, sob orientação do \\ Professor Associado Juliano de Souza Albuquerque \\ Maranhão
}

FACULDADE DE DIREITO DA USP

SÃO PAULO 
BANCA EXAMINADORA:

Orientador:

Professor Associado Juliano de Souza Albuquerque Maranhão

Professor Argüidor:

Professor Argüidor: 


\section{AGRADECIMENTOS}

Agradeço primeiramente a paciência, companheirismo e a ajuda valiosa e decisiva de meu orientador, professor Juliano Maranhão.

Agradeço a meus pais, em especial a minha mãe Neusa por sua generosidade e amor incondicional.

Agradeço à Marinalva e à Dra. Ana Paula pela valiosa ajuda e atenção a todos os meus pedidos.

À Fernanda por sua presença constante e companheirismo.

Aos meus amigos Júlio Fragoso e Marcos Dantas.

Ao meu mestre e amigo Clóvis Alonso Júnior.

E amigos que ganhei nesses longos anos de preparação: Orlando, Márcio Fonseca, Samuel, Mariana Guarda, Douglas, Gabriel, Gustavo. Aos companheiros dos últimos dias André e Juliano. 


\section{RESUMO}

Thomas Hobbes é considerado o pai do conceito moderno de Estado. O núcleo de seu pensamento nasce do esforço de construir as bases da convivência a partir da demonstração dos fundamentos racionais da autoridade política. O liame entre o debate contemporâneo, polarizado entre interpretativistas e positivistas, e o pensamento moderno, simbolizado pelo pensamento hobbesiano, identifica-se com a seguinte pergunta: sob qual justificativa devemos obedecer os mandamentos da autoridade ainda que eles nos pareceram injustos?

Palavras-chaves: AUTORIDADE; DIREITO NATURAL; POSITIVISMO JURÍDICO; HOBBES 


\begin{abstract}
Thomas Hobbes is considered the father of the modern concept of state. The core of his thinking arises from the effort to build the foundations of acquaintanceship from the demonstration of the rational foundation of political authority. The link between the contemporary debate which is polarized between positivists and interpretativists and the modern thought, which is symbolized by hobbesian thinking relates to the following question: 'Under which justification must we obey the commandments of the authority even if they seemed unfair to us'?
\end{abstract}

Keywords:AUTHORITY; NATURAL LAW; LEGAL POSITIVISM; HOBBES 


\section{SUMÁRIO}

INTRODUÇÃO....................................................................................... 8

Capitulo 1 - O problema da autoridade........................................................................ 26

1.1 Direito e moral: uma apresentação..................................................................... 26

1.2 O paradigma dualista.............................................................................. 34

1.3 O debate contemporâneo.................................................................................... 35

1.4 Joseph Raz e o problema da autoridade............................................................ 41

1.5 Autoridade e o debate da modernidade.............................................................. 47

Capítulo 2 - Hobbes e o conceito de direito....................................................................... 50

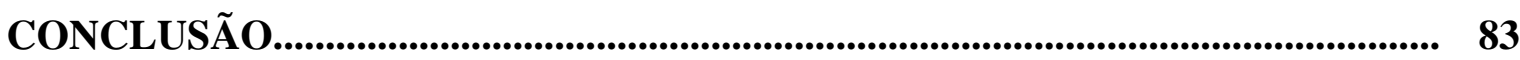

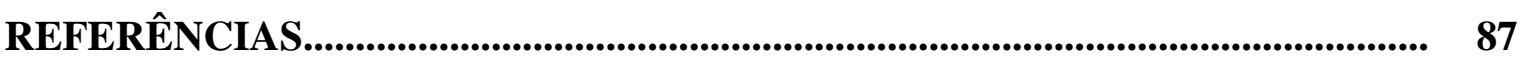




\section{INTRODUÇÃO}

A Filosofia do Direito contemporânea é caracterizada pelo debate envolvendo direito e moral, cujo signo é a dicotomia entre positivismo jurídico e jusnaturalismo. Nas últimas décadas, verificou-se o incremento das discussões, em razão do esforço teórico de desenvolver diretrizes metodológicas que favorecessem a justificação dos atos decisórios voltados a dirimir conflitos. É a ideia de justiça substantiva, que se apresenta como narrativas articuladas de justificação das arbitragem, o que envolve uma concepção de validade normativa que se abre à moralidade, e impõe a busca do fundamento último de obrigação, isto é, dos valores que subjazem a estrutura do ordenamento jurídico.

Pode-se eleger como figura de proa desse movimento o jurista norte-americano Ronald Dworkin ${ }^{1}$, que em 1967, em artigo intitulado Models of Rules, lançou amplo ataque ao positivismo jurídico, estabelecendo a agenda que está sendo cumprida pelos juristas há mais de quarenta anos ${ }^{2}$.

Segundo Dworkin, o positivismo é uma doutrina que sustenta que o direito é um modelo de regras. Dizer o que é o direito é apontar para uma regra valida, passível de ser identificada e descrita pelo jurista. Verificar se uma regra é norma juridica válida é aplicar um teste de pedigree. Os juízes devem se ater as regras para decidir casos concretos e diante de um caso difícil o juiz deve agir de forma discricionária, ou seja, ao não aplicar regras o juiz não estaria aplicando o direito, pois este é formado por regras.

O pensamento de Dworkin não é fácil de ser resumido, mas em linhas gerais, afirma que o positivismo juridico descreveu mal a prática social que caracteriza o direito, não somente por reduzir o direito ao plano das regras (não observando a existência e o papel dos princípios) com também por não captar a atuação dos juízes nos chamados hard cases. Ele conclui que o modelo positivista é incapaz de dar conta da complexidade do direito,

\footnotetext{
${ }^{1}$ Dworkin indubitavelmente é o jurista mais influente no campo dos opositores ao positivismo. No entanto, há outros juristas notáveis que se alinham a perspectiva proposta como John Finnis e Lon Fuller. Dada a miríade de teses jusnaturalistas, o agrupamento nesta ou naquela corrente sempre gera polemica, uma vez que há grandes e significativas diferenças entre os autores. Dworkin, por exemplo, não pode ser enquadrado com facilidade na perspectiva jusnaturalista, enquanto Fuller defende uma tese sobre o direito muito diferente de jusnaturalistas como Tomás de Aquino, Leibniz e Suárez, ao pensar o direito como uma prática social. Para uma visão mais aprofundada: FULLER, Lon, "Positivism and Fidelity to Law - A response to Professor Hart". Harvard Law Review, 593, 1958.

${ }^{2}$ SHAPIRO, Scott. "The Hart-Dworkin debate: a short guide the for perplexed". In: RIPSTEIN, Arthur. Ronald Dworkin. Cambridge: Cambridge University Press, 2007, p. 22.
} 
realizando critica ao modelo de subsunção e os problemas oriundos de casos em que não existem regras passiveis de serem aplicadas ao caso concreto.

Para Dworkin, ao lado das regras existem os princípios e "policies". São os princípios que permitem superar o espaço para o uso do discernimento pessoal por parte dos juízes, uma vez que eles aplicariam, em consonância com a sua tese de direito, os princípios possibilitando a existência da decisão correta.

A ideia de principio conduz à chamada guinada interpretativa, que rompe com a concepção de ciência juridica descritiva. Os juristas, juízes e operadores, estariam engajados na aplicação do direito. Ter um direito significa prover a melhor justificação, a partir dos princípios, de certas praticas políticas de uma comunidade.

A pratica juridica é entendida na dimensão factual e valorativa das praticas. Dworkin propõe a tese de que o direito é concebido como uma pratica interpretativa da experiência juridica, o que promove reorientações na postura cognitiva do direito, que deixa de defender a neutralidade e a tarefa eminentemente descritiva da ciência jurídica.. A afirmação sobre a existência de um direito depende de justificação de práticas normativas e pela concepção do direito em sua integridade. Isso significa que uma ação somente pode estar de acordo com o direito se for moralmente justificada, isto é, tratar a todos com mesma igualdade e respeito.

Essa maneira de conceber o direito a partir da captação do "juridico" nas próprias praticas sociais, em especial naquelas desenvolvidas nos tribunais, permite criticar a tese de que o direito consiste em convenções sociais. Essa guinada interpretativa superou o ceticismo quanto aos valores e possibilitou o debate em torno da ideia de justiça de forma coerente e concreta, diante da perspectiva de sua aplicação ao caso concreto.

A "guinada interpretativista" implicou na ênfase dos direitos subjetivos e no papel decisivo da teoria da argumentação, na base de um projeto radical de critica ao modelo de regras.

A sobrevalorização dos direitos subjetivos é a chave do entendimento para a revalorização do direito natural. A pergunta pela busca do direito natural, como uma ordem de valores que se situa acima da ordem juridica, no plano metafísico, parece sem sentido nas sociedades contemporâneas. A recusa de uma abordagem metafísica da temática da justiça é logo vista em John Rawls, o qual afirma que uma teoria da justiça deveria partir da própria cultura política das comunidades, construídas e formadas por instituições carregadas de 
historicidade ${ }^{3}$. Assim, a concepção de valores como ordens objetivas suprapositivas deve ser abandonada em prol da busca pela moralidade imanente às praticas sociais. O conhecimento dessas praticas, instituições e o legado comum de ideias forneceriam as bases para a identificação de princípios presentes tacitamente.

O que se sustenta é que os direitos naturais foram "positivados", no sentido em que foram incorporados pelas constituições ocidentais, que, num arco histórico que se inicia no final do século XVIII, são frutos de um lento processo gerativo de direitos humanos ${ }^{4}$ são identificadas por possuírem um extenso rol de direitos fundamentais. Direitos Humanos, Direitos Fundamentais e Direitos Subjetivos são a nova linguagem do novo sentido de direito natural que a prática juridica "interpretativista” quer efetivar.

As constituições são fruto de atos de vontade dos constituintes Não somente, entretanto: as constituições são depósitos de princípios de moral e de justiça à espera da melhor interpretação possível, os quais fundamentam a sua supremacia, inabalável e autoevidente. A Constituição é o símbolo maior da busca pela identificação e concretização da moralidade imanente as praticas sociais. Estas, informadas não somente por regras, mas principalmente por valores - nossos valores advindos do âmago de nossa autonomia e/ou reconhecidas racionalmente na força natural e imanente dos princípios comunitários -, definidas, então, pela moralidade publica, projetam-se na constituição enquanto reserva e instrumento da justiça, que deve ser efetivada - vivida - pela sociedade, entendida como comunhão dos povos, e principalmente pelas autoridades, a quem devemos respeito.

Exatamente por isso, muitos declaram que se chegou ao fim da dicotomia entre positivismo jurídico e jusnaturalismo, uma vez que aquele seria incapaz de explicar praticas normativas fundamentais componente do fenômeno jurídico, além de partir de uma concepção epistemológica ultrapassada, e que não há sentido em se falar em jusnaturalismo, enquanto um dualismo fundado numa abordagem metafísica e que não explicaria o direito, apenas legitimaria a dominação ${ }^{5}$.

Porém, as noticias da "morte do positivismo" foram muito precipitadas. A resposta, em termos gerais, veio na forma de estudos sofisticados em torno do conceito de autoridade,

\footnotetext{
${ }^{3}$ RAWLS, John. Uma teoria da justiça. São Paulo: Martins Fontes,

${ }^{4}$ BOBBIO, Norberto. A Era dos Direitos. Rio de Janeiro: Editora Campus, p. 67. Bobbio fala em multiplicação de direitos humanos. Na literatura é comum a expressão dimensão de direitos humanos.

${ }^{5}$ DIMOULIS, Dimitri.Introduçao ao estudo do direito.
} 
que se tornou um tópico central nas disciplinas de filosofia política, filosofia moral, além da filosofia jurídica.

Uma maneira de entrar nessa discussão, e observar o modo pelo qual o positivismo "reagiu", seria indagar se realmente existe autoridade quando há necessidade de apreciação de conteúdo de suas disposições antes de serem efetivamente aplicadas.

A noção fundamental de direito é obrigação. Dizer que se vive no império do direito é afirmar que o direito é capaz de regular a vida das pessoas ao impor deveres e criar obrigações. Geralmente se pensa que a obrigação é explicada pela coerção, mas se o individuo é obrigado nesse sentido, qual a diferença entre a ordem de um salteador e a de um funcionário estatal?

O ato que cria o direito não é um ato meramente de poder, esse é o sentido mais importante de obrigação juridica. Se, no entanto, a noção de obrigação não se confunde com a coerção, há uma conotação moral envolvida. É certo se falar em obrigação eminentemente juridica? E quando se pensa em dimensão moral, o que se afirma é a necessidade de apreciação de conteúdo para determinar a validade de uma norma?

Todas essas indagações convergem para o conceito de autoridade. No esforço conjunto de teorização desse fenômeno, Joseph Raz se destaca por ter elaborado a teoria da autoridade mais influente do debate contemporâneo.

A premissa é a que a existência de um sistema juridico passa pela presença da autoridade. A autoridade normativa é aquela chamada de autoridade prática, que possui o direito de comandar e que fundamenta a obrigação. A autoridade pratica cria o dever de obediência, no sentido de que há uma atividade reflexiva do destinatário diante da regra emanada da vontade da autoridade. Esta regra não direciona o comportamento pela coerção, mas atua como um guia. Há um respeito, uma adesão à regra.

A vantagem do positivismo contemporâneo é o enfrentamento da dificuldade de se explicar a natureza da autoridade, isto é, dos motivos que levam alguem a seguir regras. Ele se compromete com a agenda de construir uma teoria racional da autoridade em consonância com a explicação adequada da pratica social de seguir regras (as quais geram razoes para a ação). Afinal, o ato de seguir regras é racional ou é uma atividade irrefletida ${ }^{6}$ ? se for racional

\footnotetext{
${ }^{6}$ Gerard Lebrun, ao apresentar sua descrição do fenômeno político, afirma que, principalmente em sociedades com graves problemas sociais de exclusão e espoliação, seguir ordens é pratica tão rotineira quanto ver o sol
} 
deve existir uma avaliação de conteúdo por parte dos destinatariso. A autoridade deve passar pelo crivo racional, em outras palavras, a legitimidade advém de uma pratica reflexiva. A autoridade existe e opera a partir de razoes para a ação, as quais acabam fundamentando o direito.

Qual a raiz, no entanto, da obrigação de se observar as regras da autoridade? Se há uma adesão a regra, se seguir regras é uma pratica refletida, o fundamento da obrigação está no conteúdo da regra, ou seja, a regra passa pelo crivo da razao do destinatário, o que implicaria no descarte da importância da autoridade, uma vez que a autoridade não seria o formulador da regra mas consistiria no conteúdo intrínseco desta?

Se o comando da autoridade é obrigatório porque consiste em uma boa razão, ou seja, se a observância da regra somente ocorre após um teste de conteúdo realizado por individuos autônomos e racionais, o comando não mereceria esse nome, sendo antes um conselho. Esse esquema descaracteriza totalmente a ideia de autoridade.

É por isso, entre outros motivos, que Raz vai dizer que o direito só é possível a partir da ideia de autoridade e mais do que isso a noção de autoridade necessariamente exclui a moralidade do direito. $\mathrm{O}$ conceito de autoridade é incompatível com a apreciação do mérito moral do conteúdo.

Toda a história do pensamento jurídico se relaciona com a tensão (e conciliação) entre direito positivo e direito natural ${ }^{7}$. Os "tempos" atuais, no entanto, são marcados por questões que lhe dão o tom da especificidade, capaz de promover releituras e reconstruções de controvérsias antigas, as quais ressurgem em nova roupagem.

Na verdade, à luz de indagações atuais, há interessantes pontes que podem ser feitas com épocas passadas, especialmente com a modernidade, em que a relação entre direito e moral torna-se um problema teórico central.

nascer. Quando Lebrun deu essa contribuição, o País ainda não viva a febre por cidadania, exatamente por ter passado tanto tempo sob regime ditatorial citar autor dos bestializados. LEBRUN, Gerard. O que é poder. São Paulo: Brasiliense, 1982.

${ }^{7}$ BOBBIO, Norberto.O positivismo jurídico. Lições de filosofia do direito. São Paulo: Ícone, 2006, p.16. 
Exatamente por isso, Miguel Reale afirma que a filosofia do direito em sentido próprio nasce neste período com o aparecimento, em 1625, da obra de Hugo Grócio, De jure belli ac pacis, “o primeiro tratado autônomo de Filosofia do Direito. ",

Segundo Richard Tuck, o longo e discursivo livro de Grócio centrava-se na resposta ao desafio cético, afirmando que independentemente do desacordo moral, todos concordam no direito de autopreservação e que o ataque desnecessário e imotivado é injustificável. A sociabiliade era possível se o ceticismo fosse substituído pela adesão racional ao mínimo comum de moralidade ${ }^{9}$.

A partir de então, o esforço de construção teórica das estruturas políticas das sociedades ocidentais incorpora a linguagem dos direitos, principalmente associada ao movimento de celebração do indivíduo, da sua dignidade e da sua autonomia.

Quais seriam as similitudes entre os problemas atuais e os da modernidade? Qual o liame que pode ser estabelecido entre o complexo debate em torno do fundamento último da obrigação e as preocupações que moveram os autores do passado?

O jusnaturalismo é entendido em larga medida como uma doutrina ultrapassada e ineficaz para compreender o direito nas sociedadeas altamente complexas da contemporaneidade.

Entendido largamente como um modelo dualista, independentemente das eras e dos autores que são agrupados por esse rótulo, o jusnaturalismo pode ser definido como conjunto de princípios morais, de valor universal e imutáveis, que se insurgem como verdadeiros padrões de justiça. seu caráter normativo se realiza pela invalidação dos atos positivos, que seriam fulminados em caso de incompatibilidade. Nesse sentido, o direito que não correspondesse a esses padrão ideal não seria direito.

Ocorre que o jusnaturalismo racionalista é a ponta de lança da estruturação do direito como sistema. Na base do esforço teórico de construção dos alicerces do Estado Moderno está a própria fundamentação do direito como sistema e do dever de obediência.

Numa proposta de reconstrução desse pensamento, afirma-se que a grande questão dos jusnaturalistas figurava-se na substituição da autonomia pela heteronímia, a qual o pensamento hobbesiano é bem ilustrativo.

\footnotetext{
${ }^{8}$ REALE, Miguel.Horizontes do Direito e da História. $2^{\circ}$ edição. São Paulo: Saraiva, 1977, p.

${ }^{9}$ TUCK, Richard.Hobbes, a very short introduction.
} 
O direito, entendido como sistema de regras, retira a sua fonte de obrigatoriedade da vontade da autoridade ou do mérito racional do conteúdo da obrigação?

É essa questão que constitui a ponte entre o debate dos modernos e os contemporâneos. Ainda que o paradigma jusnaturalista seja montado em bases metafísicas, há notáveis similitudes, o que permite afirmar que o embate entre positivistas e interpretativistas, centrada na oposição entre a perspectiva justificatoria, que visa avaliar o mérito normativo dos atos de poder, e o entendimento do direito como um ato de vontade, identifica-se em larga medida com o projeto político da modernidade.

Nesse sentido, o pensamento de Hobbes mostra logo a tensão entre o direito como razao ou como vontade, em forma de preocupação com a interpretação de sua obra máxima: "num caminho cercado por aqueles que, se batem de um lado por excessiva liberdade, e, de outro, por excessiva autoridade, é difícil passar sem ferimentos por entre as lanças de cada $u m^{10}$.

O que Hobbes propõe é a conciliação entre a postura que entende como direito valido qualquer ato de soberania (ato de vontade do soberano, independentemente da apreciação do conteúdo do comando ou da justificação racional de sua autoridade), e aqueles que anulam a autoridade ao defender que não há obediência se o ato do soberano não se compatibilizar com "o correto".

É bom que se frise que tal entendimento, que atribui à Hobbes a tarefa de equacionar o problema da tensão entre autonomia e heteronomia, mitiga o seu autoritarismo, indo de encontro com versões solidificadas de seu pensamento.

Em contraste com a versão "conciliadora", há aquela que afirma ser Hobbes um típico representante do positivismo formalista e legalista.

Hobbes, ao decifrar o Homem, seria aquele que para retirar o mundo do estado de caos formularia uma proposta altamente autoritária para o problema da instabilidade social: o poder político seria entregue a um soberano absoluto e ilimitado. E independentemente do conteúdo de seus comandos supremos todos lhe devem obediência, até porque suas determinações seriam justas pelo simples fato de corresponderem a sua vontade. É a legitimação da força, o elogio supremo ao poder de fato. A monarquia absoluta, diria Hobbes, é a melhor forma de governo; não haveria espaço para a democracia - um convite à turbulência que tanto medo causava aos que pretendiam viver em paz.

\footnotetext{
${ }^{10}$ HOBBES, Thomas.Leviatã.São Paulo: Martins Fontes, 2008, p. 5.
} 
No âmbito de sua teoria política pulsaria o coração do positivismo jurídico em sua forma mais acentuada. Não somente o direito seria formado pelos comandos de um Rei que incorporaria a soberania, como os súditos deveriam obedecê-lo como o Deus terreno, afinal isso iria ao encontro dos interesses individuais, ou se gostaria de voltar ao estado de natureza, onde a "vida do ${ }^{11}$ homem é solitária, miserável, sórdida, brutal e curta”?

Não é exagero, portanto, afirmar que Hobbes foi e continua sendo um autor maldito: Hobbes tem lugar cativo, ao lado de Schmitt, Hans Kelsen em certo sentido Heidegger e Rousseau $^{12}$, e outros, no rol dos indefensáveis.

O mantra de que não podemos perder tempo com um teórico do absolutismo afirma a imoralidade daquele que despiu o homem de sua cordialidade. Hobbes é tachado de oportunista, ao elaborar uma doutrina que visava defender e legitimar a realeza: como alguém pode defender a Monarquia a não ser visando a vantagem?

Como explicar então a lógica de interesses de um homem que em seu tempo foi constantemente perseguido $^{13}$ ? Ao escrever um manuscrito que serviria como cartilha política a ser usado no Parlamento pelos defensores do Rei, Hobbes fugira para a França temendo por sua vida, lá permanecendo por uma década, onde conviveu com simpatizantes da realeza. Pois em 1651, Hobbes fora acusado de traição ao escrever um texto considerado ultrajante aos interesses reais, bem como favorável aos interesses republicanos e também ofensivo ao corpo eclesiástico. O Leviatã era uma peça de ateísmo cristão. É o Hobbes monarquista, republicano, laico, cristão fervoroso e herege. Um dos preços da demonização é a desimportância da coerência no universo conceitual...

A maldição vem de longe, encontrando eco mesmo entre contemporâneos. Hobbista e hobbismo foram termos muito impopulares no Século XVII. Hobbes, considerado um portavoz do utilitarismo e do liberalismo, teve a sua teoria malvista pelos burgueses, na medida em que, ao contrario de Locke, não vê a propriedade privada como um direito natural.

\footnotetext{
${ }^{11}$ HOBBES, Thomas. Leviatã. São Paulo: Martins Fontes, 2005. p. 109.

${ }^{12}$ Rousseau, voluntarista, é acusado de forjar uma teoria que plantou a semente do autoritarismo. Nesse sentido, a soberania, como poder absoluto de ditar a sua vontade, fez do povo a ultima ratio da política. O conceito mítico de vontade geral, reduziu a democracia à vontade da maioria, dando força de lei até mesmo à expressões de irracionalidade advindas de maiorias eventuais. Rousseau, com seu romantismo irresponsável, fragilizou a democracia ao permitir que em situações dramáticas os direitos humanos pudessem, como ocorreu, se tornar letra morta. Cf. SOUSA, José Pedro Galvão de; GARCIA, Clovis Lema; CARVALHO, José Fraga Teixeira de. Dicionário de política. São Paulo: T. A. Queiroz, 1998.

${ }^{13}$ De certa forma, é o que ocorre com Kelsen, um judeu ao qual se atribui a formulação de uma doutrina legitimadora do nazismo...
} 
Acredito, no entanto, que Hobbes tem muito a nos dizer. Para um homem que procurou vencer o argumento cético que convidava a não adoção de qualquer compromisso ético, seu compromisso com a vida passava pelo compromisso com a verdade. A dúvida hiperbólica, que dava o tom da filosofia moderna ${ }^{14}$, era o instrumento para a busca e o

\footnotetext{
${ }^{14}$ A descoberta: o sentido desse termo registra o caminho utilizado por Richard Tuck para elucidar o núcleo de toda a filosofia geral de Hobbes e, em particular, de seu pensamento político. Hobbes, pequeno livro de Tuck, é uma das principais referências dessa dissertação, o que enseja sua descrição mais detalhada, muito embora ao longo de todo o texto serão encontradas varias notas a respeito. Ele teve uma primeira edição em 1989, fazendo parte da coleção Past Masters da Oxford Univesity Press. Agora, Hobbes é um dos exemplares da coleção A Very Short Introduction. O livro possui três partes, sendo que a primeira é formada por três seções, correspondentes às fases da vida de Hobbes. Tuck reserva a segunda parte para explicitar os argumentos relativos à ética, política e ciência natural, enquanto a terceira parte destina-se à fortuna crítica. Tuck coloca o pensamento do século XVII numa encruzilhada: como superar o ceticismo sem voltar ao aristotelismo? Marcada por problemas práticos, que fulminaram o discurso humanista ciceroniano, a política moderna é determinada pelo desencanto representado pelo ceticismo de Justus Lipsius e Montaigne. Tais pensadores defendiam a impossibilidade de sustentar qualquer conhecimento seguro sobre o "mundo" natural e político, numa clara ataque a cultura aristotélica que ainda inundava o humanismo renascentista. Nesse sentido, vários pensadores trataram de lutar contra o argumento cético de incognoscibilidade de qualquer coisa sem incorrer no retorno ao aristotelismo. Filósofos como Pierre Gassendi, Renè Descartes, Marin Mersenne e Thomas Hobbes fizeram parte desse projeto que se confunde com a determinação da filosofia moderna, que encontra em $O$ Discurso do Método (1637) sua obra de referência. Para Tuck, foi em 1623, quando Galileu Galilei publicou $O$ Analisador, que o argumento revolucionário contra os céticos, e que consagrou Descartes, apareceu (foi descoberto) pela primeira vez (na verdade, a descoberta a que eu me refiro é mesmo a dúvida hiperbólica, produto do pensamento de Descartes. Porém, entre 1619 até 1637 Descartes maturou e modificou a ideia que já constava, segundo Tuck, na obra de Galileu, problema que se relacionava à teoria da percepção, à ótica e à cor.). O pensamento hobbesiano, então, é profundamente marcado pelo repúdio à Aristóteles e pela adesão a plataforma cientifica de Galileu. É por isso que Hobbes qualifica a si mesmo como cientista político, ou de ter inaugurado essa nova postura cognoscitiva no campo político, uma vez que rejetia a cultura aristotélica e se lança como alguem capaz de identificar a (alguma) certeza no campo da moral e da política (e do direito), contrapondo-se frontalmente à tese cética, vencendo-a. Então, o que Galileu realizou nas ciências naturais e Descartes na metafísica, Hobbes o fez na política e na moral (muitos autores afirmam que a influencia decisiva sobre Hobbes fora o método geométrico de Euclides, algo não enfatizado por Tuck. Em compensação, ele correlaciona a plataforma ética de Hobbes aos trabalhos de Hugo Grocio, que 1625o. Para Tuck, Hobbes não nega o ceticismo, parte dele para combatê-lo. Assim, ele enfatiza a relatividade do bom e do mau, tal como o movimento que depende fundamentalmente do ponto de observação. Nesse sentido, a política seria o espaço onde os conflitos ocasionados por esse estado de incerteza é resolvido. O projeto político hobbesiano, segundo Tuck, é oferecer uma resposta ao desafio cético mostrando a verdadeira natureza das coisas, do homem e da política. Com isso, Hobbes alça-se como um dos maiores pensadores de todos os tempos, pois, de fato, sua obra é uma novidade que dá o tom da política moderna. A obra de Tuck não se resume a atitude laudatória, chegando mesmo a criticar fortemente o esquema contratualista de Hobbes. Além disso, a obra de Tuck filia-se a toda uma "nova" corrente interpretativa de Hobbes ao enfatizar temas religiosos. Ainda que Hobbes duvide da possibilidade racional de fundar uma verdadeira teologia (não acreditava, por exemplo, que era possível caracterizar Deus), Hobbes não relega temas religiosos à fé. Esse é um dos pontos mais polêmicos de obra hobbesiana e que tanto dissabor lhe trouxe. Para Tuck, o Leviatã tem pelo menos metade de seu texto reservado a assuntos eclesiásticos, sendo essa a sua principal preocupação. Quem deveria ter a última palavra em questão de fé? Para Hobbes, o Soberano. Com isso, segundo Tuck, o Leviatã se configura de fato num ataque à independência da ordem eclesiástica Anglicana. Assim, Tuck, preocupado na explicitação do contexto intelectual em que Hobbes produziu sua obra, acaba, como ele mesmo reconhece, contribuindo fortemente para todas as disciplinas que de alguma forma se conectam com o genial Monstro de Malmesbury.
} 
encontro com a certeza. O conhecimento deveria ser alcançado em novas bases, de forma cientifica $^{15}$, o que possibilitaria seguir com confiança na vida ${ }^{16}$.

Num terreno tão movediço sobre o qual se sustenta o reino dos problemas e temas jusfilosóficos contemporâneos, visitar um autor com tal retrospecto não parece ser atitude injustificável. Quentin Skinner assinala, em As fundações do pensamento político moderno ${ }^{17}$, seu projeto de descrever o processo de formação do moderno conceito de Estado. Nesse sentido, a elaboração do amplo quadro panorâmico dos principais textos do pensamento político de fins da Idade Média e começos da moderna encontra a sua máxima expressão em Thomas Hobbes $^{18}$, que marca seu nome principalmente como teórico da política, enquanto pai do moderno conceito de Estado ${ }^{19}$. Esse fato por si só serve para mostrar a dimensão de Hobbes, cujo pensamento é a síntese de todo um grande arco de transformações culturais que se iniciaram em fins do século XIII. Hobbes simboliza, ao mesmo tempo, o fim de um ciclo e o começo de uma nova era, de enorme impacto no direito.

Hobbes é usualmente considerado como construtor de uma nova teoria política profundamente adversa à de Aristóteles ${ }^{20}$, que grassava nas universidades de então. No

\footnotetext{
${ }^{15}$ É no século XVII, consoante com famosa e clássica lição de Koyre, que o mundo conheceu uma revolução cultural, conhecida por Revolução Cientifica. Não havia até então a "divisão de trabalho" entre filosofia e ciência que marca a nossa visão atual. No século XVII e no século XVIII filosofia e ciência se identificavam.

${ }^{16}$ René Descartes, filósofo e matemático educado por jesuítas, foi o grande nome da filosofia moderna. Ainda que seu trabalho tenha permanecido incompleto, por não ter concluído o que projetara - construir também uma ética em novos fundamentos - Descartes estabeleceu o domínio onde seriam desenvolvidos os debates da metafísica e da teoria do conhecimento nos séculos subsequentes. Ainda hoje, sua obra permanece incontornável para quem pretende ter conhecimentos minimamente satisfatórios em filosofia. Antes de publicar o Discurso do Método, A Dióptrica, Os Meteoros e A Geometria, todos em 1637 (Discurso do método era propriamente um preâmbulo para todas essas obras), Descartes escreveu Regra Para a Direção do Espírito (1628) e $O$ Mundo (1629-33), projeto abandonado pela condenação de Galileu. Sua grande obra fora lançada em 1641. Meditações sobre Filosofia Primeira figura entre as maiores obras já escritas. É realmente encantador, e desestabilizador, percorrer os passos do homem que de tudo desconfia, lançando a dúvida como instrumento fundamental do conhecimento. O livro representa mesmo o núcleo da ideia de saber, na sua fragilidade e no seu encantamento. A busca por bases sólidas para a validade de afirmações sobre o mundo e sobre a moral revela mais do que qualquer outra obra o caráter da filosofia. Ver SILVA, Franklin Leopoldo e. Descartes e o discurso da modernidade. São Paulo: Ática, 1999.

${ }^{17}$ Neste estudo de incomensurável erudição, Quentin Skinner mais uma vez pretende fortalecer e legitimar seu método de analise de textos históricos. Além disso, Skinner faz uma espécie de esboço das principais (e das menores) obras do período entre o fim da Idade Média e o início da era moderna, enquanto conta o processo de formação intelectual do Estado Moderno, processo que chamarei aqui, muito baseado na leitura de Skinner, de passagem da Fortuna à Constituição. Nesse sentido, a influência de Skinner nesta dissertação é decisiva, pois é justamente o abandono da preocupação com as características e habilidades do governante, como figura incorporadora do Estado é que marca o pensamento de Thomas Hobbes.

${ }^{18}$ Trata-se de minha leitura uma vez que Skinner expressamente diz que o livro "termina" no final do século XVI, lembrando que Hobbes, que nasceu em 1588, irá lançar suas obras mais importantes na década de 40.

19 “Thomas Hobbes é conhecido sobretudo por seu pensamento político, mais precisamente como o pai do conceito moderno de Estado”. LIMONGI, Maria Izabel. Hobbes. Rio de Janeiro: Jorge Zahar, 2002. p. 5.

${ }^{20}$ Essa é a tônica do relevante trabalho de Yara Frateschi, A física da Política, em que se discute a critica de Hobbes à visão aristotélica de animal político. Essa dissertação não adota a visão da professora de que a
} 
entanto, não somente à de Aristóteles. Hobbes constrói uma teoria política que é adversária a qualquer concepção naturalística. Conforme salienta Skinner, a visão marcante do nascimento da modernidade é a de um Estado constituído principalmente como uma ordem legal e constitucional, cuja permanência e estabilidade não dependem das habilidades e dons do governante.

Quentin Skinner descreve a passagem constitutiva da modernidade:

"O passo decisivo deu-se com a mudança da ideia de governante 'conservando o seu estado' - o que significava apenas que defendia sua posição - para a ideia de que existe uma ordem legal e constitucional distinta, a do Estado, que o governante tem o dever de conservar. Um efeito dessa transformação foi que o poder do Estado, e não o do governante, passou a ser considerado a base do governo. $\mathrm{E}$ isso, por sua vez, permitiu que o Estado fosse conceitualizado em termos caracteristicamente modernos - como a única fonte da lei e da força legítima dentro de seu território, e como o único objeto adequado da lealda de seus súditos". ${ }^{21}$

Ser um teórico da Soberania (justificada) não reduz o pensamento hobbesiano, uma vez que a ideia de política moderna não se resume a definição de um poder que não encontra outro que lhe é superior numa mesma base territorial. A ideia de Estado engloba soberania não como poder de fato mas como instituição fundamentada no direito e criada por ele. Estado é elemento jurídico e por isso mesmo artificial e soberano envolve a ideia da representatividade.

Assim, o direito assume papel relevante e fundante para a nova concepção de política emergente, que se traduz de forma imediata na ideia de contrato. Se a política, ordem nãonatural, construída pelos homens para atingir determinados objetivos, funda-se no direito, qual é o conceito de direito que subjaz o núcleo do pensamento político hobbesiano e, por extensão, de toda uma nova concepção de política que marca a modernidade? Qual é a face da filosofia do direito que motiva a viagem a discursos tão decantados? Hobbes possui uma Teoria do Direito que pode nos auxiliar em nossas buscas? O "direito" de Hobbes é o mesmo dos nossos tempos?

natureza humana é identificada pelo principio do beneficio próprio, muito embora tenha se servido dela para o esclarecimento de muitos aspectos da teoria hobbesiana.

${ }^{21}$ SKINNER, Quentin. As fundações do pensamento político moderno. São Paulo: Companhia das Letras, 1996. p. 10. 
Assim, o pensamento hobbesiano surge na sua face mais radical, uma vez que eleva o homem à condição de artífice capaz de construir as suas condições de existência e a maneira com que a sociedade será estruturada, instituir o regime político, isto é, as regras que deverão indicar quem manda e quem obedece. Hobbes, apresenta uma teoria que nega a qualidade $a$ priori de certos indivíduos (e somente deles) de participar da vida política, ou de ocupar cargos importantes. A partir da igualdade fundamental dos seres humanos (que sem um poder comum cria as razoes para a guerra generalizada), forma-se o corpo político, em que cada um é componente do Leviatã, símbolo de força, poder e também de representatividade.

O projeto hobbesiano se identificava com a busca da edificação de estruturas políticas que possibilitem a convivência pacifica. Assumindo uma postura de enfrentamento da realidade do mundo, sem qualquer consideração idealista, Hobbes empreendeu o "esforço para promover o poder civil ${ }^{, 22}$.O fim da anarquia somente seria possível se os homens pudessem se relacionar de forma racional. A circunstância que promove o comportamento racional, condição para o movimento da vontade conhecida como paixão, é quem dá inteligibilidade aos atos que constituem a esfera da convivência. Nesse sentido, o direito assume tarefa fundamental, pois é ele quem cria a política (e também o mercado), esfera estável das relações intersubjetivas. A autoridade é fundada no direito e seus atos constituem direito se voltados à consagração de um bem. É a partir da concepção do direito que se pode observar quando um ato é obrigatório ou não. O conceito de direito de Thomas Hobbes, ao contrario do que se afirma, não inclui a ideia de coerção, esta um aspecto material do Estado, mas que não é capaz de servir como fundamento racional de obrigação. A regra não adquire seu status jurídico por ser emanda por um poder inexpugnável, mas por ser pautada por um contrato, que lhe dá racionalidade (e validade), e ser dirigia a quem anteriormente se obrigou a obedecer (em função de determinadas razões). Tudo passa, então, pelo entendimento do que seja a razão que se correlaciona com a lei natural, a qual exerce papel operacional na significação das praticas sociais que constituem o fenômeno jurídico.

A tarefa é apresentar o fundamento da autoridade e do direito em Thomas Hobbes, aspecto fundacional de uma nova concepção de política para sempre associada ao seu nome, e, observar de que maneira a oposição entre positivistas e interpretativistas aparece em seu pensamento.

\footnotetext{
${ }^{22}$ HOBBES, Thomas. Leviatã, cit., p. 5.
} 
Em termos gerais, o dever de obediência é uma obrigação, e não um ato meramente prudencial. Hobbes não despe a política da moralidade, pelo contrario. A lei natural para grande parte dos comentadores não é propriamente uma lei. Despidas, elas não são elementos normativos, mas máximas prudenciais, importantes para mostrar a necessidade da renuncia do direito individual absoluto que grassava no estado de natureza, em prol da efetivação do pacto de submissão.

Essa interpretação é sustentada por autores como Bobbio e Skinner. A ela se opõe aquelas as quais chamei de visões normativas. Para estas a lei natural como máximas prudenciais é entendida, como se pretende mostrar, de forma equivocada: ela possui função importante não somente porque motiva o homem para a criação da sociedade, como também fundamenta o contrato social e, além disso, talvez o mais importante, exerce papel operacional na sociedade política, mostrando aos destinatários a racionalidade que está por trás dos comandos do soberano, não meros produtos da força, mas como expressão da legalidade. Essa visão endossa uma fundamentação moral da autoridade. A lei natural exige a formação de um corpo institucional e um prática a ele associada - a arbitragem - que assume função importantíssima na explicitação das razoes de obediência e da moralidade intrínseca aos atos políticos ${ }^{23}$. O direito não se define como produto da vontade do soberano, enquanto comandos assegurados por consequência gravosa; o direito traz em si a lei natural, o que consagra Hobbes como um jusnaturalista.

Se Hobbes traz em seu trabalho um conceito de direito (centrado na ideia de obrigação) parece plausível se falar em teoria jurídica hobbesiana, ainda que o fenômeno jurídico não seja propriamente o objeto de sua obra. O direito, tal como ressaltado por diversos comentadores, exerce papel importantíssimo para a sua tarefa de traçar os contornos de uma nova concepção de política, e, desse modo, adquire papel fulcral. Hobbes não está interessado tanto em analisar o fenômeno jurídico tal como ele se apresenta na sociedade de sua época. Pelo contrario, muitas vezes nega manifestações jurídicas factualmente percebidas e significativas. Sendo um jusnaturalista, Hobbes se propõe a definir o conceito de direito do ponto de vista normativo ${ }^{24}$ e obrigacional e como esse isolamento conceitual implicaria na operacionalização do direito tendo em vista a sua função de criar a política.

\footnotetext{
${ }^{23}$ A função da arbitragem no contexto das visões normativas (jusnaturalistas ou não) não será desenvolvido nesse trabalho. Porém, como a visão jusnaturalista prevê não somente a moralidade da autoridade, uma vez que fornece, na sociedade civil, a moralidade de se obedecer ao conteúdo d

${ }^{24}$ Essa afirmação é indubitavelmente polêmica, uma vez que para Herbert Hart tanto Austin como Hobbes são modelos de direito em que se não observa o seu aspecto normativo.
} 
Os comentadores de Hobbes endossam o papel decisivo que o direito exerce na estrutura geral do argumento contratualista. A própria noção de estado de natureza é uma noção jurídica, isto é, uma situação que se define pela ausência da Lei ${ }^{25}$. Muitos autores, que procuraram entender o que Hobbes chama de estado de natureza, perceberam o aspecto seminal desse modelo de pensamento, enquanto experimento da razão, imaginada como situação experimental ${ }^{26}$. Mas antes de entender o estado de natureza como situação de anomia ideal, é preciso se perguntar o que é Lei para Hobbes e, por extensão, se a obra hobbesiana, conhecida sobretudo por seu aspecto político, também traz ou elabora uma teoria jurídica.

Por último, quero salientar que esse trabalho não se apresenta como algo acabado. Varias afirmações carecem ainda de um maior refino, embasamento e clarificação. Muitas delas consistem no desenvolvimento de tensões encontradas no trabalho de conjunto de Hobbes e que talvez não foram suficientemente respondidas pela literatura secundária, a qual abundantemente apoia versão de que Hobbes defende o autoritarismo e se enquadra no modelo imperativista do direito. Nadar contra a corrente requer músculos e preparo, o que leva certo tempo para alcançar...

Finalmente, preciso registrar que apesar do aparente ineditismo da tese central desse trabalho, que procura, no âmbito da filosofia do direito, dar uma nova visão a ideia usualmente atribuída à Hobbes da justificação do poder coercitivo do Estado (atenuando o suposto autoritarismo de sua obra), ela não tem nada de nova ou de revolucionária. Pelo contrario, nada é original aqui. Trata-se na verdade da influencia que recebi dos trabalhos de Renato Janine Ribeiro, Yara Frateschi, Thamy Pogrebencshi e, principalmente, Maria Isabel Limongi, a qual demonstrou, ainda que não explicitamente, grande conhecimento dos problemas que compõe a filosofia do direito. Além das elucidações proporcionadas por essas leituras, juntamente com o apoio de outra grande referencia, o livro de Perez Zagorin Hobbes and the Law of Nature, trago a interpretação que constitui essa pesquisa. Foi a partir das ideias desses autores que refiz toda a leitura do Leviatã e outros livros de Hobbes. Melhor do que ideias, seria dizer diretrizes interpretativas. Simplesmente, eles conduzem o seu leitor a perceber que há muito mais em Hobbes do que se imaginava de início ${ }^{27}$.

\footnotetext{
${ }^{25}$ Essa noção não é precisa, apesar de extremamente reiterada. Cf. Scott Shapiro, Legality, passim.

${ }^{26}$ Essa é uma das principais ideias que tentarei desenvolver, que procura clarificar alguns aspectos da teoria de Hobbes que tanto o levaram a ser brutalmente condenado.

${ }^{27}$ Em hipótese alguma tais "diretrizes interpretativas" se identifica com "chave de leitura”, que, tomadas a priori, sem qualquer justificativa, a não ser critérios de autoridade, moldariam a leitura para melhor direcionamento da pesquisa.
} 
E mesmo que as ideias aqui expostas possam por ventura trazer desconforto, o que se pode duvidar, tal sensação também não é difícil de explicar dadas as peculiaridades interpretativas e o conjunto desarmônico de comentários a respeito do pensamento hobbesiano. Muito embora esse fato - o da grande gama de interpretações variadas e mutuamente discordantes - há, num primeiro plano, certa visão arraigada que contamina a abordagem dos seus textos. Como bem salienta Richard Tuck:

\begin{abstract}
"Trata-se igualmente, não obstante, de uma figura incomumente difícil, visto que a maioria de seus leitores atuais o aborda com expectativas formadas, advertida ou inadvertidamente, pelas tradições insatisfatórias de interpretação que se desenvolveram a seu respeito nos dois últimos séculos."
\end{abstract}

Nesse ínterim, vale uma observação. Apesar da maioria dos autores ${ }^{28}$ enfatizar $^{29}$ que o Leviatã, obra que imortalizou Hobbes, ser o principal veículo para conhecimento de sua obra, a afirmação é ainda discutível. Um dos maiores especialistas no pensamento hobbesiano, ainda que militante em outra disciplina que não a filosófica, Richard Tuck ${ }^{30}$, o qual figura igualmente como uma referencia fundamental a este trabalho, afirma não somente que Os Elementos de Lei natural e Política" se apresenta como uma "das melhores formulações da filosofia hobbesiana",32, como também que é a "mais acessível formulação de sua filosofia geral ${ }^{33}$ ". Levando em consideração a "sugestão" de Tuck ${ }^{34}$, procurei ler toda a

\footnotetext{
28 "O livro que se presta como melhor porta de entrada na filosofia de Hobbes, e que constitui a principal fonte desta exposição introdutória, é sem dúvida o Leviatã a última e mais bem acabada versão da teoria política de Hobbes". LIMONGI, Maria Izabel. Hobbes, cit., p. 15.

${ }^{29} \mathrm{Em}$ caso de coletivo partitivo, a gramática normativa sugere (não impõe) o uso do singular.

${ }^{30}$ Richard Tuck é autor de livro muito relevante nas pesquisas sobre Hobbes. Logo no início de sua obra (intitulada Hobbes), Tuck cita um trecho de Os Elementos de Lei Natural e Política em que é assinalada a importância da circunstanciação histórica de qualquer obra para melhor compreende-la. Tal postura metodológica é constantemente reiterada, pavimentando a leitura, servindo como indicativo seguro de que se trata de uma história intelectual do pensamento hobbesiano. Exatamente por isso, Tuck ultrapassa o âmbito do Leviatã, estudando, à luz da historia, toda a obra hobbesiana e outros pensadores, inclusive os de menor expressão, tentando ressuscitar o projeto de Thomas Hobbes, isto é, identificar e explicitar as intenções do filosofo inglês. Desse modo, a premissa metodológica é a elucidação das ideias a partir do contexto intelectual que impulsionou o pensador a elaborar a sua obra.Tuck,

${ }^{31}$ Os Elementos da Lei natural e Política foi recentemente traduzido por Bruno Simões pela WMF Martins Fontes e contem uma introdução de J. C. A. Gaskin. HOBBES, Thomas. Os elementos de lei natural e política. Introd. J. C. A. Gaskin. Trad. Bruno Simões. Rev. da trad. Aníbal Mari. São Paulo: WMF Martins Fontes, 2010). Esse mesmo livro recebeu tradução portuguesa de Fernando Couto com o título de Elementos do direito natural e político. Porto: Rés, 1993.

${ }^{32}$ Richard Tuck, Hobbes, p. 34.

${ }^{33}$ Richard Tuck, Hobbes, p. 58.

${ }^{34}$ Os historiadores enfatizam que o Leviatã é o responsável pela má fama de Hobbes, embora seu nome tenha despontado à época principalmente pelo De Cive: "Hobbes construiu seu nome como o autor de um pequeno livro sobre os deveres do cidadão, publicado em 1642. Em suas várias edições, o De Cive divulgou suas ideias
} 
obra política disponível em língua portuguesa, além das versões em inglês do Leviathan e $D e$ Cive. Assim, esteve ao meu alcance as duas traduções de Leviatã ${ }^{35}$, e a de Renato Janine Ribeiro de Do Cidadão ${ }^{36}$. Consultei também traduções do Behemoth ${ }^{37}$ e de Um dialogo entre um filosofo e um jurista ${ }^{38}$. Muito embora tenha me socorrido dessas obras, o Leviatã constituise a principal fonte dessa pesquisa, o que de certa forma endossa a tese de que se trata da obra de referencia máxima do pensamento de Hobbes ${ }^{39}$.

Se como diz Aristóteles a filosofia se inicia com o espanto, enfatizo que o meu trabalho propriamente dito começou com as luzes proporcionadas por esses comentadores, as quais revelaram um Hobbes muito diferente da cultura escolar que ainda encontra eco mesmo dentro dos muros acadêmicos. Uma vez "espantado" esse Hobbes vulgarizado, pude projetar as inquietações forjadas pelo trato com problemas jurídicos e formar a leitura que agora apresento. Não custa afirmar peremptoriamente a obviedade de que os professores citados não tem responsabilidade alguma por quaisquer distorções, simplificações, equívocos e fragilidades argumentativas constantes dessa dissertação.

Apesar de todos os seus problemas, meu trabalho ainda flerta com alguns caminhos possíveis de serem trilhados e que não foram desenvolvidos aqui. Entre eles, o papel da

sobre a necessidade de uma soberania indivisa entre uma ampla, e em sua maior parte admiradora, audiência continental”. SORELL, Tom. Introdução. In: ____ (Ed.). Hobbes. Tradução André Oides. São Paulo: Ideias $\&$ Letras, 2011. Tom Sorell, autor de uma biografia altamente recomendada de Thomas Hobbes, acrescenta que mesmo antes da publicação do livro de 1642, Hobbes era conhecido nos círculos parlamentares como autor de uma peça manuscrita, não publicada, mas de ampla circulação, que mais tarde receberia o nome de Elements of Natural Law and Politics. O De Cive fora publicado em Paris em 1642 e teve segunda edição em 1647. O fato de De Cive ter sido escrito em latim, ensejou a produção de traduções não-oficiais e dispostas para a venda nas livrarias da Inglaterra. Assim, até abril de 1651, quando surgiu o LEVIATÃ, Hobbes possuía duas obras políticas de ampla circulação na Inglaterra, o que já o fizera deveras conhecido: os Elementos de Lei e o De Cive. É bom ressaltar ainda que Hobbes já havia publicado um livro na Inglaterra em 1637, A Briefe of the Art of Rethorique.

${ }^{35}$ A primeira tradução publicada foi a de João Paulo Monteiro e Maria Beatriz N. da Silva, pela Abril Cultural, edição pertencente à coleção Os Pensadores. A segunda tradução disponível foi a supervisionada por Eunice Ostrensky e realizada novamente por João Paulo Monteiro e Maria Beatriz N. da Silva, além de Claudia Berliner, feita a partir da edição da Cambridge University Press, organizada por Richard Tuck. HOBBES, Thomas. Leviatã ou Matéria, forma e poder de um estado eclesiástico e civil. Tradução de João Paulo Monteiro e Maria Beatriz Nizza Silva. 2. ed. São Paulo: Abril Cultural, 1979. (Os pensadores); HOBBES, Thomas. Leviatã. Tradução de João Paulo Monteiro, Maria Beatriz Nizza Silva e Cláudia Belinger. Rev. Téc. Eunice Ostrensky. 1. ed. São Paulo: Martins Fontes, 2003; HOBBES, Thomas. Leviathan. Edited by Richard Tuck. Cambridge; New York: Cambridge University Press, 1996.

${ }^{36}$ HOBBES, Thomas. Do cidadão. São Paulo: Martins Fontes, 1998.

${ }^{37}$ HOBBES, Thomas. Behemoth. Trad. de Eunice Ostrensky. Belo Horizonte: Ed. da UFMG, 2001.

${ }^{38}$ HOBBES, Thomas. Um diálogo entre um filósofo e um jurista. Trad. de Maria Cristina Guimarães Cupertino. São Paulo: Landy, 2001.

${ }^{39}$ Para Michael Oakeshott, o Leviatã é a maior, senão a única, obra-prima de filosofia política escrita na língua inglesa: "the Leviathan is the greatest, perhaps the sole, masterpiece of political philosophy written in the English Language” Michael Oakeshott, “Introduction”, In: Thomas Hobbes, Leviathan, p. viii. 
educação dos cidadãos $^{40}$ na concepção geral de autoridade tal como foi exposta, o que ensejaria uma comparação mais profunda entre a teoria do direito de Hobbes e as contemporâneas concepções de autoridade. Nesse sentido, diante da tentativa de sustentação da tese de que a coerção não está contida no conceito de direito de Thomas Hobbes, vem à mente aquele que é considerado um dos maiores expoentes da teoria analítica do direito: Joseph Raz. Um maior aprofundamento da trilha aberta pelas pesquisas que salientam temas religiosos no contexto geral da filosofia de Hobbes: a questão da fé em Deus seria o seu grande problema, o que, se levado ao pé da letra, provocaria um turning point decisivo em toda a sua fortuna crítica, alastrando-se a temas insuspeitos, como o problema da obrigação, sua concepção de autoridade e a questão da tolerância. Além disso, seria importante maior clarificação da ideia de autonomia em Thomas Hobbes, comparando-a com outros grandes nomes da filosofia moderna: Rousseau e Kant. Outro ponto é a correlação entre o conceito de direito e liberalismo na obra hobbesiana, tema de historia complexa e diversificada.

Assim, se abrindo às criticas, essa dissertação talvez tenha o mérito de confirmar uma platitude: os grandes clássicos sempre tem algo (novo) a dizer. Em palavras mais refinadas, "um clássico é um livro que nunca terminou o que tinha para dizer",41.

A dissertação contem dois capítulos. No primeiro, apresenta o contexto do debate contemporâneo envolvendo direito e moral, destacando, ao final, à ideia de autoridade, dando voz ao principal teórico deste topico central na teoria analítica do direito: Joseph Raz. As ideias de Raz são representativas da busca pelos juristas dos critérios de legitimação do direito, como tambem estabelecem a ponte que ira buscar na modernidade, precisamente nas ideias de Hobbes, o entendimento mais amplo dos alicerces morais e racionais da autoridade. O capitulo contem seções preliminares deste debate. Primeiramente, apresenta o aspecto peculiar da filosofia do direito enquanto saber constituído em torno de problemas advindos da prática juridica, os quais convergem na "eterna" relação entre direito e moral. Depois, apresenta-se um breve esboço da doutrina do direito natural racionalista da modernidade, entendido como o moldelo jusnaturalista por excelência. É principalmente esse direito natural,

\footnotetext{
${ }^{40} \mathrm{~A}$ leitura mais comum é a de que a natureza humana é única e absoluta, nada podendo ser feita para mudá-la. Nesse sentido, a educação teria pouca utilidade. Tal tese, muito difundida, ainda requer maiores elucidações, uma vez que as pesquisas contemporâneas apontam cada vez mais a influencia do humanismo renascentista na obra de Hobbes, o que poderia destacar o papel de cidadãos virtuosos para o bom funcionamento da República.

${ }^{41}$ CALVINO, Ítalo. Por que ler os clássicos. São Paulo: Companhia das Letras, 1993. passim.
} 
tão importante para o desenvolvimento da ciência juridica no século XIX, que identificado ao paradigma dualista do direito natural, que é acusado de ser modelo explicativo fraco para o fenômeno jurídico nas sociedades complexas. O que se pretende é reapresentar o pensamento jurídico da modernidade à luz do debate contemporâneo, o que irá preparar a apresentação da atualidade da teoria da autoridade de Thomas Hobbes.

O segundo capítulo tratará do núcleo do pensamento jurídico-politico de Thomas Hobbes e tenta explicitar os argumentos que estão por trás da opção racional dos indivíduos de substituir a autonomia pela heteronomia. Procura-se primeiro apresentar a versão mais difundida do pensamento hobbesiano, entendido como justificação do absolutismo, tendo em vista a imoralidade da natureza humana. O pessimismo antropológico seria o fator responsável pela escolha da heteronomia. Já o segundo argumento é o jusnaturalista. Nesse sentido, a lei natural tem plena capacidade de se efetivar na sociedade, gerando um encontro com a moralidade pela possibilidade da racionalidade adquirir a sua plena realização. A terceira via é a da legalidade e afirma a existência de uma atmosfera obrigacional criada pelo contrato social. Nesse sentido, a razao juridica responde a todo momento porque se deve obedecer a autoridade. Com isso, observa-se que o argumento da justificação do poder coercitivo do Estado não passa pela sua definição de direito e que as razoes de obediência se prendem à própria ideia de legalidade vigente em uma sociedade onde é possível o estabelecimento de relações racionais e a operatividade da lei natural. 


\title{
Capitulo 1 - 0 problema da autoridade
}

\subsection{Direito e moral: uma apresentação}

\author{
Herbert Hart dedica parte do primeiro capítulo de seu livro mais famoso ${ }^{42}$ a
} apresentação do solo em que nasce e se desenvolve o conjunto de indagações que constitui a filosofia do direito ${ }^{43}$. O caminho escolhido para despertar a sensibilidade filosófica no tocante ao fenômeno jurídico e para apresentar o problema sobre o qual se debruçou foi o da perplexidade ${ }^{44}$.

${ }^{42}$ HART, Herbert. $O$ conceito de Direito.Lisboa: fundação Calouste gulbenkian, p. 5 e ss.

${ }^{43}$ A filosofia do direito e/ou a teoria do direito é disciplina complexa. Assim sendo, é difícil traçar o seu conceito, aquele que abranja todas as suas manifestações. Miguel Reale a define como "estudo críticosistemático dos pressupostos lógicos, axiológicos e históricos da experiência jurídica". REALE, Miguel. Filosofia do Direito, vol 2, p. 285 Miguel Reale assinala também que a "Filosofia do Direito é a filosofia mesma enquanto o pensador tem como objeto de estudo e de analise a experiência jurídica" (NOBRE, Marcos; REGO, José Márcio. Conversas com filosofos brasileiros. São Paulo, Editora 34, p. 16), assinalando a sua visão de que a filosofia do direito é um capitulo da filosofia em geral. Tal concepção situa-se ao lado de outra que enxerga na filosofia do direito um saber muito peculiar, típico dos juristas. Já se disse que a filosofia do direito pode ser concebida como um capítulo da filosofia geral no plano do direito, mas essa assertiva é misteriosa: dado que a principal tarefa da teoria ou da filosofia do direito é identificar o direito, qualquer projeção que se faça nessa esfera já de antemão parte de uma noção de direito. nesse sentido surge a pergunta: como sabemos o que sabemos sobre o direito? A singularidade, a força e a perplexidade dessa pergunta revelam que a filosofia do direito tem um aspecto singular que somente com esforço a faz dialogar com outros campos da filosofia em geral. Assim, é duvidoso que a filosofia do direito seja a projeção da filosofia no campo do direito, uma vez que os juristas estão envolvidos com problemas tão específicos que a sua atividade, seja ela dogmática ou filosófica, acaba adquirindo o caráter peculiar do seu objeto. De fato, como foi visto, a filosofia do direito retira a sua vitalidade de problemas oriundos da "experiência juridica" ainda que seja muito difícil dizer a natureza dessa prática. Nessa esteira, autores como Norberto Bobbio e Michel Troper propõem uma classificação: existiriam a "filosofia do direito dos filósofos" e "filosofia do direito dos juristas" (TROPER, Michel, Filosofia do Direito.São Paulo: Martins Fontes, 2008, p. 17). Poder-se-ia afirmar como especificidade da filosofia do direito dos filósofos o seu aspecto de projeção, isto é, seria a filosofia mesma aplicada ao fenômeno jurídico (visão de Reale). Nesse sentido, haveria uma proximidade importante entre a filosofia do direito, a politica e a moral, principalmente no tocante ao estudo da justiça. Exatamente por isso, é notória a inspiração jusnaturalista, que adota a concepção universalista do direito. Essa perspectiva, pelo seu caráter especulativo, encontra certa rejeição. Já a filosofia do direito do juristas rejeita o enfoque especulativo e mergulha na "experiência juridica" se abeberando dela para formular os problemas que darão o toque de especificidade a esse saber. Conforme salienta Bobbio, não se procura essências, mas se parte diretamente do fenômeno jurídico. Esse enfoque não realiza o método de projeção mencionado, pelo contrario, procura analisar a racionalidade juridica. Para Troper, essa perspectiva aparece como uma descrição das praticas jurídicas tendo em vista um alto nível de abstração, buscando os fundamentos últimos da experiência juridica. O mesmo Troper ressalta a fragilidade dessa classificação, uma vez que a filosofia do direito dos juristas tambem realiza especulações, nascidas de opções conceituais vinculadas a concepções eminentemente filosóficas.

${ }^{44} \mathrm{O}$ vinculo com a filosofia logo se estabelece. Ainda que a própria noção de filosofia seja um dos principais temas da própria filosofia, a sua natureza, ou o tipo de preocupação que a identifica para além de seu isolamento conceitual, advem da admiração, do espanto, do susto com o mundo. A própria vida torna-se um problema quando se indaga sobre as suas reais condições de possibilidade. Aristóteles assim sintetiza o tema: "Foi, com efeito, pela admiração que os homens, assim hoje como no começo, forma levados a filosofar, sendo primeiramente abalados pelas dificuldades mais óbvias, e progredindo em seguida pouco a pouco até resolverem problemas maiores (...) ora, quem duvida e se admira julga ignorar: por isso, tambem quem ama os mitos é, de certa maneira, filosofo, porque o mito resulta do maravilhoso. Pelo que, se foi para fugir à ignorância que filosofaram, claro está que preocuparam a ciência pelo desejo de conhecer, e não em vista de qualquer utilidade": ARISTÓTELES, Metafísica, os pensadores, p. 214. Aristóteles primeiro afirma que todo homem desejam por sua natureza conhecer, levando a crer que a filosofia, como saber especulativo, planta raízes 
Primeiramente, assinala a discrepância entre a aparente tranquilidade do "homem comum" $" 45$ na tarefa de citar exemplos de direito e a do jurista, envolvido num torvelinho infindável de formulações abstratas e curiosas, que parecem negar o óbvio. Para os primeiros, o direito não é mais do que um conjunto de preceitos governamentais dirigidos ao comportamento humano tendo em vista a organização da sociedade. Hart explora grandemente essa "pré-compreensão", procurando, lentamente, produzir problematizações que indicam a raiz das argumentações jurídico-filosóficas. Alias, a perplexidade se move pendularmente, ora associada à sensação causada pelos trabalhos dos juristas ${ }^{46}$, ora à própria natureza do fenômeno jurídico ${ }^{47}$.

na natureza humana. A filosofia é desejo de conhecer ainda que fora de qualquer utilidade, pois os homens tem prazer no conhecimento. Nesse sentido, a filosofia volta para si mesma, uma vez que o fim do pensamento é o próprio conhecimento. O desejo de conhecer, em contraponto ao ensinamento platônico, nasce do espanto que se biparte no espanto causado pelo mundo e no espanto da revelação da próprio ignorância, que motiva a busca pelo conhecimento. No caso de Hart, o que se infere de seu texto, é que o inicio do processo filosófico, do "espanto" com a "realidade" do jurídico requer um despertar, uma preparação para a atitude filosófica. A perplexidade presente no mistério do fenômeno jurídico é apresentada a partir da perplexidade que a filosofia do direito provoca naqueles que estão mergulhados no chamado senso comum: "Todos os homens são filósofos. Mesmo quando não tem consciência de terem problemas filosóficos, tem, em todo o caso, preconceitos filosóficos. A maior parte destes preconceitos são as teorias que aceitam como evidentes: receberam-nas do seu meio intelectual ou por via da tradição. Dado que só tomamos consciência de algumas dessas teorias, elas constituem preconceitos no sentido de que são defendidas sem qualque verificação critica, ainda que sejam de extrema importância para a aç̧ão pratica e para a vida do homem. Uma justificação para a existência da filosofia profissional ou acadêmica é a necessidade de analisar e testar criticamente estas teorias muito divulgadas e influentes. Tais teorias constittuem o ponto de partida de toda a ciência e de toda a filosofia. São pontos de partida precários. Toda a filosofia deve partir das opiniões incertas e muitas vezes perniciosas do senso comum acrítico. O objectivo é um senso comum esclarecido e critico, a prossecução de uma perspectiva mais próxima da verdade e uma influencia menos funesta na vida do homem." POPPER, Karl. Em Busca \& um Mundo Melhor. Lisboa: Editora Fragmentos, 1989, p. 165. A estratégia de Hart é despertar a atitude filosófica, conduzir o leitor à indagações, as quais, ainda que ligadas "ao modelo simples de direito", geram as afirmaçoes típicas da filosofia do direito, ou seja, "algumas das muitas afirmaçoes e negações respeitantes à natureza do direito que à primeira visa, pelo menos, parecem estranhas e paradoxais. " Hart, idem, p. 6.

${ }^{45}$ A noção de "homem comum" ocupa espaço importante nas reflexões sobre o fenômeno jurídico. Goffredo Telles Junior, sem explicitamente conjuga-lo, se utiliza da noção ao aproximar o seu leitor da ideia de norma, como algo que expressa o comum, o bem comum, o "caminho do meio', o razoável, noções ligadas ao reto, ao justo, ao correto, o que perfilha o autor de uma abordagem jusnaturalista. Cf. TELLES Jr., Goffredo da Silva.Iniciaçao na ciencia do Direito.São Paulo: Saraiva, 2011. O direito como a norma, como o normal, associado ao homem médio também é objeto do livro de José Ingenieros.O Homem medíocre. Nenhuma dessas acepções parecem corresponder à formulação hartiana, que se utiliza de termos como "men", "englishmen" e "most educated people", numa alusão a cidadãos ou destinatários, participantes ativos da sociedade política, o que lhe retira qualquer conotação pejorativa, como sujeito inculto, pouco esclarecido.

46 "essas são apenas algumas das muitas afirmaçoes e negações respeitantes à natureza do direito que à primeira vista, pelo menos, parecem estranhas e paradoxais. Algumas delas parecem entrar em conflito com as crenças mais firmemente enraizadas e ser facilmente refutáveis; de tal forma que nos sentimos tentados a respoder certamente que as leis são direito, pelo menos uma espécie de direito, ainda que haja outras;" ver. HART, Herbert.O conceito de Direito.Lisboa: Fundação Calouste Gulbenkian, 1994

${ }^{47}$ Este trecho do trabalho quer exatamente ressaltar que a filosofia do direito está associada à perplexidade presente no fenômeno juridico, nem sempre possível de ser percebida pelo "homem comum" ou mesmo pelos chamados "operadores do direito", talvez porque se percebam realmente "operadores de uma máquina - o direito - a qual, para o bom desempenho de seu trabalho, não exija conhecer seus fundamentos, apenas o "modo como funciona". 
De fato, o direito, por mais que possa ser entendido primeiramente como "um conjunto de normas que objetiva regulamentar o comportamento social"48, conduz qualquer pessoa a uma serie de indagações que faz romper a aparente tranquilidade que esse esquema suscita. Porque, ao lado da força (como evidência) da estreita vinculação entre Direito e Lei (preceito estatal genérico), também figura a imagem de Direito como ligado à moral, isto é, como representando qualquer aspiração a ser atingida pelo Estado e pela coletividade. Ao lado do direito figuram-se outros valores, como a liberdade, a igualdade e a justiça.

Essa ambivalência do direito, que aparece como regras emanadas do poder político e também como aspiração moral, é encontrada ao longo de toda a historia do pensamento ocidental. Alguns exemplos podem ilustrar como o problema relativo a natureza do direito se relaciona diretamente com a relação entre direito e moral

Robert Alexy, ao falar do problema sobre o conceito de direito, fornece um exemplo retirado de Xenofonte:

"Assim, apenas para citar um exemplo, até hoje são distintas as respostas que se dão à pergunta relatada por Xenofonte, feita por Alcebíades a Péricles: 'Então, quando um tirano apodera-se de um Estado e impõe aos cidadãos o que eles devem fazer, isso também é uma lei?' (Xenofonte 1917, p. 16), se entendemos por "lei" uma lei juridicamente válida." 49

Igualmente, Thomas Hobbes também destaca a questão:

"B: Must tyrants also be obeyed in everything actively? or is there nothing wherein a lawful King's command may be disobeyed? What if he should command me with my own hands to execute my fater, in case he should be condemned to die by the law?",50

Mesmo em livros de dogmatic jurídica, voltados a outros problemas, esse problema fundamental da filosofia do direito aparece:

"Demasiadamente influenciados pelo espírito da escola, os positivistas o
confundem com a lei. Mas pecam pelo excesso, podendo-se objetar-lhes o
que Cícero há dois milênios já vislumbrava, quando tachava de mais que
estulto admitir que o furto ou assassínio se tornassem justos em razão de o
legislador, num gesto tresloucado, o permitir como norma de
comportamento",51

A citação acima procura diferenciar norma juridica válida e atos de tirania, afirmando que o direito requer para a sua existência que as normas possuam qualquer

\footnotetext{
${ }^{48}$ DIMOULIS, Dimitri,

${ }^{49}$ ALEXY, Robert. Conceito e validade do direito.São Paulo: Martins Fontes, 2011, p. 3.

${ }^{50}$ HOBBES, Thomas. Behemoth or the Long Parliament. London: Frank Cass, 1969.

${ }^{51}$ PEREIRA, Cáio Mário da Silva.Instituições de Direito Civil. Vol 1.Rio de Janeiro: Editora Forense, 2004 , p. 8.
} 
dimensão de moralidade ${ }^{52}$. Mais do que isso, afirma que o direito existe mesmo para proteger as pessoas de atos de poder que venham coloca-las em perigo ou aviltá-las de alguma maneira. Coloca-se assim frontalmente oposta a propostas como as de Kelsen, que parece despir o direito de qualquer conexão com a moral:

"O sistema de normas que se apresenta como uma ordem jurídica tem
essencialmente um caráter dinâmico. Uma norma juridica não vale porque
tem um determinado conteúdo, quer dizer, porque o seu conteúdo pode ser
deduzido pela vida de um raciocínio lógico do de uma norma fundamental
pressuposta, mas porque é criada por uma forma determinada - em última
análise, por uma forma fixada por uma norma fundamental pressuposta.
Por isso, e somente por isso, pertence ela à ordem jurídica cujas normas
são criadas de conformidade com a norma fundamental. Por isso, todo e
qualquer conteúdo pode ser Direito. "53

A liçao de Kelsen conota uma visão trágica, a de que o homem figura-se diante de uma força inexpugnável, um Leviatã todo-poderoso, capaz de impor pela força todo e qualquer comando.

Será essa a face do direito? O fenômeno jurídico nada mais é do que a pura força, caracterizado pela heteronomia e pela coerção?

Dimitri Dimoulis dá uma definição de direito que parece se aproximar a essa noção. Após fazer trazer um repertóro de definições, fazendo lembrar que o direito é fenômeno altamente complexo e controverso, afirma que a postura teórica deve se livrar do engajamento e assumir a neutralidade crítica para o bom cumprimento da tarefa de definir o direito. Isso é importante porque permitiria ver que o direito é fruto da vontade dominante em determinada época e lugar. Rejeitando enfaticamente a visão universalista, que apregoa a universalidade e imutabilidade do direito, afirma que este nada mais é do que :
“composto por normas que regulamentam o comportamento das pessoas na sociedade. (...) O direito é um conjunto de regras que indica aquilo que devemos (ou não devemos) fazer. Em outras palavras, o direito estabelece sempre um dever ser, uma serie de mandamentos que devem ser seguidos por seus destinatários. (..) o direito é um dever ser de particular natureza. Quando o médico diz ao paciente 'pare de fumar' dá uma ordem muito

\footnotetext{
${ }^{52} \mathrm{O}$ equivoco da citação está em não reconhecer que o próprio direito é quem fornece o sentido objetivo dos atos e da expressão da vontade. O direito cria o direito; o direito determina o sentido jurídico dos fatos. O direito pode ser entendido como sistema de significados, Se um determinado sistema jurídico afirma que todo e qualquer ato de soberania é valido isso significa que ele faz parte do sistema, devendo observar as formas préestabelecidas. Em outras palavras, o ato do soberano adquire o significado objetivo conferido pelo próprio direito, sendo crime um sentido dado pelo próprio direito, independentemente da avaliação subjetiva dos indivíduos participantes da comunidade. Porém, é importante frisar que esta dissertação advem do reconhecimento de que a autorreferencialidade do direito tem limitações ao fornecer um esclarecimento cabal sobre o fundamento da obrigação.

${ }^{53}$ KELSEN, Hans.Teoria Pura do Direito. Tradução João Baptista Machado. $6^{\circ}$ ed. São Paulo: Martins Fontes, 2003, p. 221.
} 
diferente daquela emitida pela lei que proíber fumar nos edifícios públicos. O medico formula um dever ser, uma regra de conduta que está no interesse do paciente. No entanto, o médico não tem a possibilidade (nem a vontade) de cobrar a sua execução: o paciente é livre para seguir ou ignorar as recomendações médicas. $O$ direito é um dever ser particularmente forte e ameaçador. Sua aplicação não só pode ser exigida, mas é tambem imposta mediante a ameaça de penalidades que implicam, se for necessário, a utilização da violência física." 54

Sendo o direito um fenômeno objetivo e contrafático, isto é, capaz de se impor independentemente da vontade ou das opções valorativas dos destinatários, como ele é capaz de afetar os nossos direitos e obrigações.

Segundo Norberto Bobbio, foi somente no seculo XX por força da obra de Hans Kelsen que os juristas alargaram o seu horizonte e entenderam o direito como um conjunto de normas. Assim, para o cumprimento da tarefa prática de identificar o direito voltaram-se não mais para a consideração da norma isolada, mas para o ordenamento jurídico como um todo. Assim, uma determinada norma é considerada regra juridica se pertencer ao ordenamento jurídico.

Há outros critérios para a identificação da norma juridica. Qual a diferença entre a ordem dada pelo salteador e aquela emitida por um funcionário? para o primeiro se diz que houve uma coação, isto é, a vítima foi forçada a agir temendo consequencias danosas. Já o segundo comando é legitimo, isto é, gera um dever de obediência. Diz-se que no caso do funcionário o seu ato de vontade gera uma obrigação. Pode-se afirmar que a ordem do funcionário é juridica porque é reconduzida a mais alta cadeia de imputação normativa, a constituição, ou então, porque é respaldada pelo poder soberano, que detem o monopólio legitimo da força num dado território. O que se quer salientar, no entanto, é que no caso da ordem do funcionário o destinatário sentiu-se vinculado, reconheceu que se tratava de uma comando juridicamente obrigatório.

Qual é a fonte de obrigaçao? o que torna o comando do funcionário diferente do salteador? não está implícita uma conotação moral como fundamento último da obrigaçao? Encarar uma regra como obrigatória não implica em dizer que é correto agir de acordo com a lei?

\footnotetext{
${ }^{54}$ DIMOULIS, idem, $p .38$.
} 


\section{Conexões entre direito e moral: o jusnaturalismo com dualismo}

Seria possível ampliar o leque de imagens que salietam a complexa relação entre o direito e moral. Exatamente por isso, toda a tradição do pensamento jurídico convive com a oposição entre positivismo jurídico e jusnaturalismo.

A história do pensamento jurídico ${ }^{55}$ foi dominada pela visão jusnaturalista, nos seus mais diversos matizes, até o século XIX, quando foi sucedida em decorrência de alterações nas estruturas das sociedades ocidentais ${ }^{56}$ pelo positivismo jurídico ${ }^{57}$.

Não é possível, no entanto, pensar o jusnaturalismo como uma corrente teórica única e homogênea sem incorrer em grande dose de simplificação. Exatamente por isso, as teorias jurídicas são situadas, isto é, entendidas como semânticas de uma época, em que se acentua, à luz das peculiaridades do tempo, o vinculo entre o direito, como referencia, e o perfil histórico do pensamento que o toma como objeto.

Tendo em vista esse fator, ainda assim é possível se falar em modelo, estratégia muito utilizada pelos juristas ${ }^{58}$. Norberto Bobbio afirma que a expressão jusnaturalismo é

\footnotetext{
${ }^{55}$ Em contraponto à visão universalista do direito, somente se poderia falar em teoria do direito quando o seu objeto adquirisse tamanha diferenciação, tamanha autonomia que a consciência de sua singularidade assumisse força o suficiente para a invocação do esforço intelectual de compreendê-la e identifica-lá. Segundo Miguel Reale, ainda que ele sustente a visão universalista do direito (ubi societas ibi jus), "é somente num estágio bem maduro da civilização que as regras jurídicas adquirem estrutura e valor próprios, independente de normas religiosas ou costumeiras e, por via de consequência, é só então que a humanidade passa a considerar o direito como merecedor de estudos autônomos. Essa tomada de consciência do direito assinala um momento crucial e decisivo na história da espécie humana, podendo-se dizer que a conscientização do Direito é a semente da Ciência do Direito.” Reale, Miguel. Liçoes Preliminares do Direito. $27^{\circ}$ edição. São Paulo: Saraiva, 2004.

${ }^{56}$ De certa forma, toda a chamada Idade Moderna (1453-1789) foi um período de transição, uma vez que assistiu ao lento processo de formação do capitalismo (a literatura sobre esse processo é imensa. Entre tantos, ver DOBB, Maurice. A evolução do capitalismo. São Paulo: Nova Cultural, 1988), que iria chegar ao seu ápice justamente na chamada Revolução Industrial. No tocante ao direito, as mudanças passaram pela progressiva secularização e a concomitante complexificação da sociedade, com cada individuo sustentando diferentes ideias de vida e concepções valorativas. O que se verificou foi o declínio da adesão a valores objetivos. Max Weber afirma que na modernidade grassa o politeísmo de valores, processo com largo impacto no direito. Cf. WEBER, Max. Economia e Sociedade: fundamentos da sociologia compreensiva. $4^{\circ}$ ed. Brasília: editora Universidade de Brasília, 2012. A ciência do direito se utiliza largamente de dicotomias para organizar os seus conceitos, noções e esquemas tendo em vista ao cumprimento de sua função de promover a decidibilidade dos conflitos com o mínimo de perturbação social possível.

${ }^{57}$ Fora a própria ideia de sistema, relegada pelo jusnaturalismo racionalista, que ensejou, como efeito prático, a maior alteração no entendimento do direito, uma vez que conduziu ao processo de codificação, acompanhado pelo constitucionalismo, hierarquização de fontes, declínio do direito costumeiro e surgimento cada vez maior do direito escrito. Nesse sentido, os códigos são os símbolos da destruição e triunfo do jusnaturalismo ver FERRAZ Jr, Tercio Sampaio. Introdução ao estudo do direito. $2^{\circ}$ ed. São Paulo: Atlas, 1994, p.73.

${ }^{58}$ A consciência da singularidade das questões específicas que forma a filosofia do direito permite a sua unificação a partir de modelos e dicotomias que visam fornecer não somente um quadro ilustrativo, como permitir o desenvolvimento desses problemas, no intuito de clarifica-los e até mesmo se utilizar dos conceitos para a sua aplicação a problemas concretos. A ciência do direito se utiliza largamente de dicotomias para organizar os seus conceitos, definições, postulados e outros recursos tendo em vista ao cumprimento de sua função de promover a decidibilidade dos conflitos com o mínimo de perturbação social possível. Assim, a própria ideia de Filosofia do Direito acompanha o próprio desenvolvimento de modificações importantes no
} 
apropriada apenas para designar a experiência juridica dos povos ocidentais ao longo do século XVII e XVIII, independentemente da força e presença da cultura clássica na conformação da doutrina jusnaturalista. ${ }^{59}$ Bobbio denomina as escolas jusnaturalistas anteriores ao aparecimento da famosa obra de Hugo Grócio, de 1625, como o "modelo alternativo", revelando a maior importância da doutrina do direito racional na construção do saber jurídico.

O jusnaturalismo racionalista abriga grande variedade de autores, tais como Hobbes, Grocio, Locke, Pufendorf, Leibniz, Kant e Espinosa, cujas obras formaram o debate de onde se retiram os elementos que constituem o modelo. Assim, dada a complexidade desta escola, passível de ser apreendida por diferentes ângulos e descrita por diferentes maneiras, propõe-se um enquadramento mínimo que poderá facilitar o entendimento a atualidade do debate em torno do jusnaturalismo.

Primeiramente se apresentara os contornos do direito natural moderno, para posteriormente apresentar, tambem de forma sintética, o paradigma dualista do direito natural. Entre eles não há certamente muita diferença, uma vez que o jusnaturalismo racionalista, como já foi salientado, é visto como o modelo jusnaturalista por excelência. O importante é caracterizar o dualismo que abriga a dicotomia entre positivismo jurídico e jusnaturalismo. Esse enquadramento é que tanta repulsa despertou em autores como Kelsen.

Advoga-se aqui que esse dualismo é a causa de distorções, uma vez que apresenta uma caricatura do jusnaturalismo e amesquinha o seu potencial de clarificação dos problemas atuais. O retorno à modernidade, centrado em um dos seus principais expoentes, Thomas Hobbes, berço da corrente do jusnaturalismo racional, é motivada tambem pela percepção do esgotamento da dicotomia como modelo explicativo do fenomento jurídico. Como se verá em seção deste capítulo, os contornos do debate contemporâneo entre direito e moral ultrapassam o esquema dualista. A grande riqueza do pensamento jurídico da modernidade está no esforço de construção racional do Estado, o que determina a teorização da autoridade e do

direito historicamente situado e que promoveram a formação deste tipo de saber especifico a que se chamou ciência do direito FERRAZ Jr. idem. O processo de codificação, que rompeu com o chamado paradigma do direito natural, modificou tambem o tipo de saber juridico consistente na reflexão sobre os fundamentos do direito num nível de abstração o mais amplo possível. Assim, faz sentido a divisão proposta por Michel troper entre "filosofia do direito dos filósofos" e "filosofia do direito dos juristas", sendo esta última fruto da própria formação e consolidação do positivismo juridico, uma vez que a própria constituição dos problemas filosóficos advem da "prática jurídica". o que se visava era a construçao de um conhecimento confiável, o que acentua a presença, e não a determinação, da experiência juridica por excelência, que é o conflito a qual o jurista é convocado a agir. Tais ponderações implicariam na tarefa dificílima de diferenciar teoria do direito e filosofia do direito. O mesmo Michel Troper assinala que "o bom senso manda que tomemos ambas as expressões como sinônimas", deixando claro que a sinônima destes não implica na identificação entre filosofia dos filosofos e filosofia dos juristas. Assim, para o intuito direto deste trabalho,

${ }^{59}$ GROCIO, Hugo.Do Direito da Guerra e da Paz. 
fundamento de obediência. No bojo deste movimento, está a tensão e a conciliação entre autonomia e a heteronomia.

Em termos sintéticos e com o objetivo de uma aproximação ao tema, o jusnaturalismo moderno formula, a partir de uma concepção de homem e de sociedade, uma concepção de política e uma teoria sobre a moralidade que disciplina a conduta humana.

Parte-se da noção de que o direito é um dado, presente de alguma forma na natureza, passível de ser reconhecida pelo homem. A cosmologia, que lato sensu era a tônica dos "modelos" anteriores, enquanto leis que regulavam tanto o homem como a natureza, foi substituída por uma visão singular do ser humano, um ente específico, com natureza própria, e que, portanto, tem uma disciplina diferente de outros seres.

A singularidade do ser humano está na razão, fator capaz de promover a sociabilidade. É justamente a marca da racionalidade que conferirá a especialidade do jusnaturalismo racionalista, isto é, um conjunto de leis (morais e/ou jurídicas) que formarão a sociedade $^{60}$.

Ao partir de noções fundamentais, presentes na natureza humana, derivam-se leis, capazes de serem entendidas e fundamentadas pela razão. A noção de derivação ou inferência resulta mesmo da aplicação do método geométrico no campo ético, o que marca a noção nascente do encontro com a certeza, num mundo marcado pela turbulência.

É esse (novo) mundo, cada vez mais complexo, que irá impactar a concepção de direito, destituindo-o progressivamente de seu caráter ético e moldando-o de acordo com os imperativos da sobrevivência. O método more geomético, assim como a nova concepção de ciência advinda dos trabalhos de Galileu, registram a necessidade de conhecimento voltado à questões práticas, instrumentais, o que gera um saber tendencialmente neutro. O pensamento da época é marcado pela ideia de sistema, enquanto conhecimento ordenado dedutivamente, com notáveis influencias no direito. Então, partindo-se de princípios fundamentais, todo o edifício do conhecimento era construído e imaginado como um todo sistemático, de caráter lógico-demonstrativo.

A homogeneidade produzida pela ideia de sistema provoca a concepção de direito como um todo harmônico formando por regras, ainda que os teóricos do direito natural relativizassem, ainda que não olvidassem, o direito positivo, formado por diversas fontes (direito costumeiro, direito legislado, direito romano, direito canônico etc) que ainda não haviam passado pelo processo de hierarquização (que teria como raiz o próprio

\footnotetext{
${ }^{60}$ Há ambivalência na ideia da razão originar leis, uma vez que pode ser percebida como razão como legisladora ou razão que "descobre" as leis.
} 
jusnaturalismo) que seria uma das marcas significativas da experiencia jurídica do século XIX.

É aqui que já se começa a perceber as razoes que levaram teóricos como Bobbio a considerar a escola do direito natural racional com o modelo mais adequado de jusnaturalismo. Entre outros motivos, a percepção de que o direito existe como dado objetivo passível de identificação por processos racionais começa a tomar forma. Como foi assinalado, transformações sociais impulsionaram o movimento de autonomia da moralidade, insurgindose como uma entre outras esferas (como a política) dotada de racionalidade singular. Tal fenômeno conduziu ao problema da relação entre direito e moral, que, daí por diante, seria a tônica do esforço de identificação do direito.

Quando o homem moderno se pergunta se a guerra pode ser justa, ele traça um projeto de aliança entre a certeza e a justiça, tendo em vista a necessidade de intervenção e domínio da natureza, que aparenta ameaça. A conotação operacional e a referencia imediata a natureza racional do homem marca o direito natural racional. A ideia de sistema permite a previsibilidade e o caráter operativo do direito.

\subsection{0 paradigma dualista}

Segundo Carlos Santiago Nino, o jusnaturalismo se estrutura da seguinte maneira:

“a)Uma tese de filosofia ética que afirma a necessidade de princípios morais e de justiça universalmente validas e acessíveis à razão humana.

b) Uma tese relativa à definição do conceito de direito, segundo a qual um sistema normativo ou uma norma não podem ser classificados como 'jurídicos' se estão em desacordo com aqueles princípios morais ou de justiça."

Para Nino, essas duas teses somente caracterizam o jusnaturalismo se estiverem juntas. A ausência de uma delas não permite a apresentação deste ou daquele autor como jusnaturalista.

Assim, reiterando, o jusnaturalismo afirma que o direito natural existe e pode ser identificado.

A afirmação de sua existencia implica em dizer que se trata de uma instancia objetiva, a mesma para todos os homens, seres dotados de razao e que portanto podem encontrar a certeza e a justiça e assim pautar o seu comportamento por essas normas.

O dualismo afirma então necessariamente que existem dois direitos, duas intancias objetivas e vinculativas. Mais do que isso, entre elas existe uma hierarquia. $\mathrm{O}$ direito natural é

\footnotetext{
${ }^{61}$ Idem, p. 32.
} 
superior e anterior ao positivo, de modo que a incompatibilidade entre o direito positivo e o natural implica na invalidade do direito positivo. Todo direito que contrarie a lei natural é injusto.

Enquanto o jusnaturalismo é dualista, porque prevê a existência de dois direitos necessariamente compatíveis, o positivismo jurídico é monista, no sentido de que somente existe o direito positivo, aquele advindo de fontes sociais, passível de ser identificado empiricamente.

\subsection{0 debate contemporâneo}

A descrição que aqui será feita não pretende ser exaustiva e nem servir como guia do cipoal de tendências e novas frentes de pesquisa que formam o debate contemporâneo. Temse em mente apenas dar breves notas que servirão de farol para iluminar o problema que se pretende responder.

Um importante fenomeno do pensamento juridico moderno é que ao lado da estruturação de um sistema de regras, entendidas como derivadas de noções fundamentais num método more geométrico, figura-se a formação de esferas distintas de racionalidade. A política surge como cateogria autônoma ao lado da moral, sendo que a linguagem dos direitos é sintoma importante desse processo.

A modernidade conhece tambem o inicio de um processo progressivo de autonomizaçao do direito. assim, o problema teórico fundamental da filosofia do direito, que é a relação entre direito e moral, é posto com propriedade nessa época ${ }^{62}$.

A autonomia do direito, no sentido de sua separação da moral, assinala o surgimento da corrente hegemônica do dirieto até meados do seculo XX: o positivismo juridico.

O melhor seria utilizar o termo positivismos para indicar a realidade de um conjunto dispare de teorias e tendências. A partir das lições de Santiago Nino é possível sem muita preocupação com o rigor classificar as correntes positivistas, dividindo-as em ideológica, cética, formalista e conceitual.

Para os fins deste trabalho, é importante explicar o que se entende por positivismo ideológico, nomenclatura atribuída à Bobbio. ${ }^{63}$

Em termos gerais, o positivismo é a tese moral que impõe a obediência a lei, qualquer que seja o seu conteúdo. Essa versão de positivismo é a verdadeira responsável por

\footnotetext{
${ }^{62}$ Para uma visão abrangente desse fenômeno e de todo o arco de desenvolvimento do período v. TUCK, Richard. Natural Law theories. Cambridge: Cambridge University Press, 1981.

${ }^{63}$ BOBBIO, Norberto. Positivismo Jurídico, p. 223.
} 
sua acepção pejorativa. Em outras palavras, uma vez existente o direito ou sistema juridico, as pessoas a ele submetido devem deixar de lado suas convicções pessoais, seus valores e suas razoes e aderirem incondicionalmente a norma emanada das "autoridades" "64. Onde há direito, há incondicional obrigação moral para obedecer a lei, ainda que ela seja injusta, difamante ou ultrajante $^{65}$. O positivismo ideológico tem relação com a razão pratica, na medida em que envolve um questionamento sobre o que é certo ou errado fazer).

Renato Janine Ribeiro traz a notícia da história do russo Pavel Morozov, um adolescente russo que denunciou o seu próprio pai ao poder soviético. No regime ditatorial que se difundiu então, qualquer comentário contrario ao status quo resultava em crime. O pai de Pavel foi condenado ao campo de concentração. O jovem russo tornou-se, por força do governo, um símbolo de virtude, após o seu assassinato ocorrido na vila onde morava. Este é um exemplo clássico do positivismo ideológico.

Outro teórico que é frequentemente lembrado como exemplo de adesão ao positivismo ideológico é K. M. Bergbohm, cuja teoria foi elaborada no seculo XIX.

Outra maneira de apresentar o sentido do positivismo ideológico é que ele afirma a injustificabilidade de qualquer forma de resistência. Em outras palavras, não há fundamento juridico para o direito de resistência.

Indubitavelmente, a forma de positivismo mais importante é a conceitual ou metodológica. É conceitual porque a preocupação é única e exclusivamente a definição do conceito de direito. A identificação do direito passa pela observância de propriedades valorativas? Talvez seja a pergunta que simboliza essa corrente.

Como se viu, desde o inicio da era moderna formou-se campos específicos com pretensão de autonomia. Com o tempo, recrudesceu-se o processo de autonomizaçao da esfera de moralidade, cujo ápice é a vertente do positivismo que estamos apresentando.

O positivismo conceitual procura estabelecer critérios científicos que determinem a existencia do direito. busca-se identificar o direito a partir de fontes sociais, ou seja, independentemente do mérito moral da disposição de direito. geralmente o positivismo conceitual é associado ao ceticismo ético, cujos representantes mais lembrados são Kelsen e

\footnotetext{
64 A palavra autoridade vai entre aspas porque o sentido forte de autoridade no contexto do positivismo ideológico todo e qualquer mandatário merece obediência, pelo simples fato de estar no poder. É a alusão à soberania de fato.

${ }^{65}$ No tocante à teoria da autoridade de Joseph Raz, sua afirmação de que o direito tem aspiração moral não permite enquadrá-lo sob o rótulo de positivista ideológico, embora se observe a ambiguidade já assinalada. $\mathrm{Na}$ verdade, a teoria da autoridade trabalha justamente com a questao da legitimidade normativa do sistema juridico, algo que Finnis vai "radicalizar" trabalhando com a noção de bem moral ideal, reabilitando a visão jusnaturalista.
} 
Weber. O ceticismo ético ataca a tese ética do paradigma jusnaturalista, isto é, a impossibilidade da existencia nas sociedades complexas (caracterizadas pelo politeísmo de valores e agudo dissenso moral) de princípios morais vinculativos universais e imutáveis. $\mathrm{O}$ direito natural, como toda e qualquer moralidade, pertence ao campo subjetivo, intangível ao alcance da ciência.

É aqui que a formulação positivista mais famosa ganha o seu realce: a existência do direito é uma coisa; seu mérito e demérito outra ${ }^{66}$ Segundo o positivismo jurídico, a existência do direito depende da presença de certos fatos e não da existência de determinados elementos que se coadunem com padrões de justiça ${ }^{67}$.

Então, de forma recorrente, observa-se a postura de identificação do direito como ele é, tal como ele se apresenta empiricamente na sociedade, independentemente de considerações morais, sejam elas de natureza objetiva ou não. Porem, surgem seria duvidas quanto aos fatos que devem ser levados em consideração no momento de apreciação objetiva do direito. Para determinar o direito em qualquer circunstancia se requer de antemão conhecer propriedades necessárias para que um determinado sistema normativo seja qualificado como jurídico. Quais são as propriedades necessárias, relevantes ou suficientes que permitiram determinar um sistema jurídico independentemente de seus aspectos morais? é aqui que entra a ideia de ciência, a grande elemento dessa verso de positivismo.

Para se captar o juridico é preciso a formulação de insturmentos adequados que permitam que o resultado desse processo cognitivo, em forma de proposições verdadeiras sejam passiveis de controle intersubjetivo.

O positivismo conceitual quer saber se é possível conhecer um ente juridico sem que seja necessário qualquer relação com a moralidade. Dentro das varias conexões possíveis entre o direito e a moral, o conhecimento do direito não requer qualquer alusão à propriedades valorativas. Se existe um bem moral, não importa, o que se defende é que sua existencia, caso isso se verifique, não afeta a validade do direito. O positivismo conceitual atua principalmente na tese dois do paradigma jusnaturalista.

Reiterando, para os positivistas, o direito existe, pode ser conhecido objetivamente pela ciência, e sua determinação prescinde da relação com valores. O que é importante reiterar é que os positivistas conceitual nada afirmam sobre à razao pratica. Em outras palavras, da

\footnotetext{
66 "the existence of law is one thing; its merit and demerit another. Whether it be or be is on enquiry; whether it be or not conformable to an assume standard is a different enquiry'. John Austin, The Province of Jurisprudence Determined

${ }^{67}$ Mais para diante, será discutida a relação entre positivismo e o ceticismo ético, o que marca diferença entre positivistas como Austin e Kelsen. Para aquele, há padrões de justiça objetivos, ao contrario de Kelsen e Weber.
} 
existencia do direito não implica o dever de obediência. Há uma diferença substancial entre positivismo ideológico e o positivismo conceitual.

É importante frisar que o desenvolvimento das teorias jurídicas que vão na contramão da tese positivista tambem não pode ser enquadrada no paradigma jusnaturalistadualista, alicerçada na velha dicotomia entre jusnaturalismo e positivismo juridico.

A alusão a valores não se resume a aceitação da existencia de princípios objetivos universais e validos que sobrepairam a ordem juridica.

Simplificadamente, os valores saíram da nuvem metafísica e se dirigiram para o solo da moralidade comum, identificada com as instituições historicamente forjadas e que identificam um povo. A moral de que se fala hoje é aquela que identifica dada comunidade, que traduz a sua cultura política. ${ }^{68}$

Diante desse "novo" entendimento de moralidade, há varias relações possíveis entre direito e moral, bem como diferentes perspectivas de abordagem ${ }^{69}$. O que interessa é a identificaçao do direito e o perfil da nova postura cientifica, se descritiva ou prescritiva.

Então, pode-se entender, tal como o paradigma dualista, na existencia de uma moralidade objetiva suprapositiva, ou na ideia de moral como cultura política (moral dominante).

O positivismo conceitual visou determinar e descrever o "ente" juridico independentemente de concepções valorativas. Como o compromisso cientifico é com a certeza e a objetividade, a alusão a moral torna o objeto de estudo inalcançável para o discurso cientifico. A estratégia positivista foi reduzir o direito à propriedades necessárias. Nesse sentido, uma norma pode ser sentida como justa, porem isso não é necessário para a existencia do direito. há direito valido, no caso de Kelsen, independentemtne de sua justiça.

Isso é importante, porque após o ataque dos interpretativistas, houve uma reorientação na agenda positivista. A Teoria Pura do Direito reserva espaço reduzido comparativamente ao restante do livro ao problema da interpretação juridica. Apesar da importância, sagacidade e complexidade da teoria da interpretação de Kelsen, há sem duvida uma relativização diante do elemento central que é o conceito de validade.

As questões relativas ao raciocínio juridico e a metodologia juridica passam agora para a linha de frente na pauta de pesquisas $^{70}$. A enfase na metodologia juridica reflete a

${ }_{68}$ A discussão nesse tema é abundante e diversificada. Ao lado de Dworkin, um autor extremamente significativo é John Rawls. Ver WACKS, Raymond. A very short introduction to Philosophy of Law. Oxford: Oxford University Press, 2006.

${ }^{69}$ Pode-se pensar, por exemplo, no perfil progressista e civilizador que o direito pode exercer na cultura política de uma comunidade ou o impacto que a moral ideal exerce na formulação de do direito, na atuação dos juízes, no desenvolvimento econômico e formulação de políticas publcas. 
preocupação de observância de outros elementos relativos ao fenômeno juridico considerados até então como menos importante para a caracterizaçao do direito.

Nesse sentido, a tese dworkiniana de tomar o direito como integridade é um sinal dessa nova postura anti-reducionista. $\mathrm{O}$ direito se abre à moralidade, no sentido em que a moral passa ser concebida como fenômeno relevante na caracterização do direito, bem como a prática argumentativa assume papel significativo nessa orientação.

O impacto mais significativo é que a questao de teoria eminentemente cientifica, bem como a ideia de autonomia são relativizadas, senão desprezadas. O engajamento dos juristas e dos juízes para efetivar os valores comunitários e para realizar a leitura moral da constituição não permite a articulação de direito como esfera dotada de legalidade especifica ${ }^{71}$.

A proposta de Dworkin é tão sofisticada como audaciosa. Ela afirma que o juiz, ao decidir o conflito, deve realizar o direito, ou seja, elaborar uma interpretação construtiva a partir da moralidade consistente nas instituições e na cultura política formada historicamente. Assim, integridade não é precisamente rejeição ao reducionismo que caracterizava a preocupação dos positivistas, mas a coerência das ações das autoridades de efetivar o direito que é entendido como uma ordem de regras e princípios. O que importa é aplicar o direito e isso exige uma postura engajada de interpretação que leve em conta o imperativo de consagração da igualdade. Ou seja, a pratica juridica volta-se para a efetivação da moralidade que é inafastavel do direito. surge a tese da única resposta correta, o que elimina a discricionariedade da decisão judicial. Os princípios juridicos seriam o resultante da interpretação construtiva da pratica social juridica da comunidade política e são eles que fundamentariam a decisão correta ${ }^{72}$.

A discussão da teoria do direito contemporanea leva a uma nova percepção do papelo do Direito em nossas vidas. A visão de direito como integridade tem ao menos um duplo aspecto: ela diz o que o direito é, no sentido de revelar aspectos do fenômeno juridico que não podem ser descartados (permite a clarificação e o melhor entendimento do fenômeno juridico), e prescreve o que o direito deve ser, no sentido de orientar juízes e demais operadores na tarefa de aplicar o direito.

\footnotetext{
${ }^{70}$ Cf. MACCORMICK, Neil.Argumentaçao juridica e teoria do direito. São Paulo: Martins Fontes, 2006 e FARALLI, Carla.A filosofia contemporânea do direito: temas e desafios. São Paulo: Martins Fontes, 2006.

${ }^{71}$ A teoria do direito de Ronald Dworkin é muito sofisticada e apresentou modulações e reorientações ao longo do tempo. Uma boa introdução ao tema é o livro de Stephen Guest, do qual me servi fundamentalmente para a realização dessa leitura. GUEST, Stephen.Ronald Dworkin. Rio de Janeiro: Elsevier.

${ }^{72}$ Oscar Vilhena explica a oposição, no tocante a leitura moral da constituição e da pratica interpretativaconstrutiva, entre Hart e Dworkin. VIEIRA, Oscar Vilhena.A Constituição e sua reserva de justiça. São Paulo: Martins Fontes, 1999, p. 184-202.
} 
Há implicações importantes dessa concepçao. Não somente afirma que o juiz não deve aplicar regras que contradizem valores morais, como tambem assevera que em casos difíceis os juízes devem recorrer a princípios morais para solucioná-los. Além disso, altera o estatuto da ciência juridica, uma vez que deixa a sua postura avalorativa e descritiva, para assumir o papel de elaborar instrumentos metodológicos que auxiliem os juízes na tarefa de identificar, construir e aplicar princípios, bem como refletir sobre as razoes da aplicação das regras.

Mais do que isso, o direito invade uma área até então relativizada, pois a teoria positivista não era capaz de explicar as razoes de obediência ao direito. o que está em jogo é o entendimento global da relação entre individuo, sociedade e instituições políticas.

Dizer que o direito é uma ordem coativa da conduta humana, auxilia na tarefa de identificá-lo, e descrevê-lo. Ao mesmo tempo, tal definição leva à concepçao de que os indivíduos agem em torno de seus próprios interesses e a obediência ou o respeito ao direito se faz pelo temor da coerção. É preciso reconhecer que para muitos ou para a maioria das pessoas o direito aparece como uma autoridade, no sentido de que a relação é pautada pelo respeito, de que o direito diz o que fazer e esse comando é entendido como algo que deve ser levado em consideração não pelo temor. Para essas pessoas o direito ou os preceitos aparecem como um guia para a ação.

Até então, a ciência juridica afirmava ser elemento desnecessário para a definição do conceito de direito a relação entre os indivíduos e o direito, não se atentava com o choque entre as razoes morais e as razoes jurídicas do homem concretamente considerado.

A defesa de uma conexão conceitual entre direito e valores, identificada com a tese de direito como integridade, permite uma reorientação do entendimento do direito como um sistema de regras. A postura de engajamento dá ao interprete e aplicador confere ao interprete e ao aplicador o dever de se desviar das regras e acessar os princípios tendo em vista a finalidade do direito de concretização da justiça?

Essa pergunta sem duvida tem alcance altamente significativo, pois confere à instancia judicial um papel político fundamental, uma vez que o direito é assumidamente produto da elaborçao judicial. Os juízes adquiriram legitimidade para contrapor as suas razoes às razoes da regra e nesse movimento refletir não somente o conteúdo das disposições jurídicas mas contrapo-las aos seus valores morais enquanto autoridade legitima a criar o direito.

Tomando-se a constituição, o entendimento das expressões que aludem diretamente à princípios, esperam a sua concretização no caso concreto. Os juízes possuem a autoridade de 
determinar esses conteúdos, principalmente quando estão em jogo dilemas morais graves que afetam toda a coletividade, ou tal tarefa deve ser deixada a cargo do parlamento ${ }^{73}$

É realmente perturbador o alcance desse entendimento. O que está em jogo na busca pela conexão necessária entre direito e moral é a relação entre autoridade e a razao pratica. Essa relação perpassa não somente as instituições juridico-politicas, em relevo a atividade judicial, como tambem a relação entre os indivíduos e o direito. isto porque a interpretação construtiva de princípios e a decisão que ultrapassa as regras e acessa a finalidade do direito impõe uma reflexão sobre os fins últimos do direito

Para quê existe o Direito? Qual é a finalidade que se pretende alcançar? Como o direito afeta as nossas vidas? Como o direito é capaz de dizer o que eu devo fazer?

Exatamente porque há uma relação necessária entre direito e moral, a pergunta sobre o que se deve fazer, afeta a razao prática, que determina o que é certo ou errado tendo em vista o comportamento.

Cabe a pergunta: qual é o fundamento da autoridade do Direito para decidir o que devemos fazer? Qual é o fundamento último da autoridade?

\subsection{Joseph Raz e o problema da autoridade}

A partir de uma gama de indagações e respostas gera-se uma situação de indefinição e perplexidade que constitui e legitima um tipo de saber denominado largamente de filosofia do direito, que alcança alta abstração a partir de problemas estreitamente relacionados com determinadas práticas, principalmente aquelas que se identificam com a resolução de conflitos em caráter definitivo realizados por um órgão especifico, o judiciário, função estatal por excelência.

Retomando, um dos tópicos mais importantes e perenes da filosofia é a relaçao entre direito e poder, particularmente, direito e força.

A visão simples de direito, que identifica direito e lei, em se sentido mais profundo, afirma que o Direito é fruto do Estado , enquanto expressão do soberano de fato. Em outras palavra, por trás de cada norma juridica esta um ato de poder, que vincula os indivíduos pela coerção. O fenômeno juridico é explicado porque em ultima instancia a fonte de obrigação é o poder de fato.

$\mathrm{Na}$ verdade, isso não é uma explicação, isto é, não há ali, em consonância com a ideia de normatividade, a explicação da natureza do direito, ferida que está a ideia de

\footnotetext{
${ }^{73}$ Waldron, Jeremy. A dignidade da legislação.São Paulo: Martins Fontes, 2001.
} 
autonomia do direito quando se identificou direito e força, pura expressão do poder. Não existe propriamente a Lei, porque não existe a Legalidade, capaz de conferir a certos fatos e a determinados atos, um sentido objetivamente jurídico.

Como já foi explicado, o projeto dos juspositivistas era identificar algo eminentemente juridico, determinar a maneira de conhecê-lo e descrevê-lo, ainda que a natureza desse objeto dependa da perspectiva de qual se parta $^{74}$, seja a científica, seja a dos próprios indivíduos enquanto participantes das praticas sociais associadas à regras (e das razoes e justificativas eminentemente jurídicas dessas praticas) ${ }^{75}$.

A explicação da natureza do direito, como sentido objetivo de determinadas práticas sociais, encontra hoje, no conceito de Autoridade um lócus privilegiado, como se tentou mostrar.

Não somente no direito, no entanto. É possível dizer que a ideia de autoridade se tornou aspecto fundamental na agenda dos estudos políticos e morais. Exatamente por isso, dado a importância e o alcance do conceito, qual o sentido de autoridade que interessa ao debate contemporâneo do direito, já que o fenômeno pode ser examinado por diferentes ângulos e perspectivas?

Alguns estudos sobre a autoridade tem índole sociológica, debruçando-se nas relações causais, nos fatores históricos, políticos e sociológicos que efetivamente edificaram a autoridade, bem como explicam sua dinâmica interna e sua estabilidade.

A questão da autoridade que importa ao debate aqui presente é a que a toma internamente, isto é, do ponto de vista, como foi mencionado, normativo, tendo em vista a relação e tensão entre o aspecto juridico e o moral da autoridade.

Em outra palavras, pergunta-se sobre as razoes de legitimidade da autoridade, quando e por qual motivo as decisões e atos de poder, que impactam diretamente a vida e a liberdade dos indivíduos, são legítimos.

O que Joseph Raz elaborou, assim como os demais autores que participam dessa discussão, é uma teoria normativa da autoridade, o que impacta consideravelmente as marcas e objetivos da ciência juridica. Ou seja, de um posicionamento neutro parte-se para uma postura que visa determinar as razoes subjacentes às práticas de poder, o que possibilitaria

\footnotetext{
${ }^{74}$ KELSEN, Hans.Teoria Pura do Direito. São Paulo: Martins Fontes, 2003.

${ }^{75}$ HART, Herbert.O Conceito de Direito. Lisboa: Fundação Calouste Gulbenkian, 2004.
} 
observar se o que está por trás da existência da autoridade, bem como o sentido efetivo dos atos de poder, seu alcance e, principalmente, limites $^{76}$.

O debate em torno da autoridade política é complexo. Pretende-se apenas lançar breves notas sobre a questão, trazendo à baila as contribuições do autor de maior destaque deste tópico central no debate jurídico, moral e político.

Scott Shapiro divide o conceito de autoridade em duas categorias ${ }^{77}$ : autoridade teórica e autoridade pratica ${ }^{78}$. Quem é autoridade teórica? Shapiro responde que são os homens com grande conhecimento em determinado assunto: são os peritos, os experts, aqueles a quem respeitamos por serem conhecidos (reconhecidos) pelo domínio de um determinado saber. Da mesma forma que a autoridade teórica influencia o comportamento dos indivíduos, a autoridade prática dirige o comportamento alheio, mas de forma diferente, porque tem direito de fazê-lo. Conforme ensina Joseph $\mathrm{Raz}^{79}$, um médico (autoridade teórica) age de forma diferente de um sargento (autoridade prática): enquanto o médico influencia o comportamento de seus pacientes, dando-lhes conselhos que influenciam os seus comportamentos, o sargento tem o direito de mandar, isto é, o poder jurídico de direcionar o comportamento dos seus subordinados.

O médico age na esfera de uma razao: "faremos o que for melhor para a nossa saúde". É isso que faz as pessoas procurarem um médico. A razão que influencia o comportamento já está dada de antemão, a espera de seu "preenchimento" pelo médico (perito), que indicará (sugerirá) o que fazer para alcançar ou manter saúde.

Um soldado, como todo individuo, no desempenho de sua função, elabora razoes para a ação. Ele tem concepções de certo e errado, diretrizes para se posicionar e agir desta ou daquela maneira. Quando recebe uma ordem superior (de uma autoridade) o conflito de razoes já estabelecida é impactada pela ordem, ou seja, por uma razão que "vem de fora". Pode ser que essa razão externa se coadune com a razão prevalecente do soldado, ou com uma delas, de modo que haja concordância com a razão superior. Mas não é isso que está em jogo, uma vez que a diretriz estabelecida "de cima", ou melhor, "externamente" não foi respeitada

\footnotetext{
${ }^{76}$ A questão de limites, como se argumentará, encontra em Hobbes aspecto decisivo. Sua teoria de construção racional da autoridade política que passa pela existência e justificação do poder absoluto do soberano não implica em autoritarismo. A noção de limites não passa propriamente pela contenção pelo poder mas por aspectos cognitivos, que identificam a própria ideia de legalidade fundada na razão, e não na coerção.

${ }^{77}$ SHAPIRO, Scott, "Authority" In: COLEMAN, J. L.; SHAPIRO, S. The oxford Handbook of jurisprudence and legal theory. New York: Oxford University Press, 2002. p. 382-439.

78 "theoretical authority" e "practical authority".

${ }^{79}$ RAZ, Joseph. The morality of freedom.oxford: New York: Clarendon Press, 1986, p.64.
} 
por seu valor intrínseco ${ }^{80}$. O que houve foi uma troca das razoes do soldado pela diretiva do superior. Resta a indagação: o soldado, na relação com o seu superior, faz uma apreciação de conteúdo da diretriz que determina o seu comportamento?

Como foi explicado acima, a filosofia do direito contemporânea ultrapassou a agenda do positivismo epistemológico, de modo que o conhecimento do direito não passa pela captação de propriedades necessárias, que em sua ausência descaracterizariam o fenômeno como juridico. O que se coloca como ponto central da discussão é que a complexidade do direito não pode ser abarcada pela estratégia reducionista. Em outras palavras, o positivismo juridico (na sua versão epistemológica) não está apto a dizer por que alguem deve obedecer ao direito, não daria conta das razoes de obediência.

O grande mérito das discussões em torno da autoridade, e talvez a responsável pela sua centralidade no debate contemporâneo, é a relação que se estabelece entre direito e a razão pratica. Tendo em vista o exemplo trabalhado, o que me faz obedecer aos ditames do detentor do poder político? O que explica a obrigatoriedade dos"comandos" da autoridade? Por que esse comando é jurídico, isto é, o que faz com que a vontade da autoridade torne-se "algo" jurídico? Por que a autoridade tem o direito de comandar? Por que a autoridade é autoridade (e não um tirano) ${ }^{81}$

A preocupação principal é com a legitimidade. A teoria da autoridade visa responder quando os comandos são legítimos e, sendo legítimos, jurídicos, ainda que possam persistir no plano da realidade, conforme se verá quando se analisar a teoria da autoridade de Hobbes, que se aproxima com a raziana.

Toma-se como palco do teste de juridicidade o plano da razão prática, isto é, no balanço de razoes que dirigem o comportamento. Raz elabora uma teoria da autoridade, isto é, fornece instrumentos racionais para a apreciação da legitimidade dos atos da autoridade prática, e depois projeta, como um teste, esta teoria no direito.

Em palavras mais sucintas, a teoria da legitimidade visa responder em que condições e circunstancias alguém tem o direito de dirigir (autoridade prática) o comportamento de outros?

\footnotetext{
${ }^{80}$ Como afirma Robert Paul Wolff, "obedience is not a matter of doing what someone tells you to do. It is a matter of doing what he tells you to do because he tells you to doit" WOLFF, Robert Paul.In defense of anarchism.Berkeley, CA: University of California Press, 1970.

${ }^{81}$ Em um excerto presente neste capitulo, retirado do Behemoth de Thomas Hobbes, há um estranho jogo de expressões. Hobbes utiliza como sinônimos os termos tyrans e lawful king. Este é um exemplar da dificuldade de se interpretar a obra hobbesiana.
} 
Assim, quando, por exemplo, um funcionário estatal, em serviço, se dirige de forma imperativa à conduta de outrem, é possível aplicar a teoria da autoridade para perceber se aquele funcionário tem o direito de influenciar decisivamente o comportamento alheio.

A teoria da legitimidade não se volta para um teste de conteúdo da diretriz da autoridade; não se observa a justiça intrínseca dela, como correspondência a qualquer padrão de justiça objetivo, ou concordância com concepções de bem moral. A teoria da legitimidade é aplicada "lá atrás" para justificar a moralidade da autoridade, tentando responder porque a autoridade tem o direito de compor o balanço de razoes dos indivíduos por uma diretriz que pode assumir qualquer conteúdo.

Que razão é essa capaz de nos fazer suspender (substituir) a nossa avaliação e trocála pela determinação da autoridade? Em palavras mais sucintas, por que eu devo obedecer a lei?

Todo o debate converge para a discussão em torno da natureza, limites e alcance da autoridade.

Raz vai dizer que o direito só é possível a partir da ideia de autoridade e mais do que isso a noção de autoridade é necessariamente exclui a moralidade do direito. o conceito de autoridade é incompatível com a apreciação do mérito moral do conteúdo.

Porem, nota-se uma ambiguidade no pensamento de Raz, uma vez que é necessário para a existencia da autoridade uma justificação moral que permita a troca da autonomia pela heteronomia.

Se, para existir o direito é necessária a autoridade e esta não subiste se em cada momento suas ordens tiverem que passar por um teste de conteúdo, então a avaliação de conteúdo deve existir na moralidade que sustenta sua autoridade. Se o ser humano realizasse a troca unicamente em prol de interesses, não haveria uma razao propriamente na base do sistema. Este se assentaria em razoes prudenciais incapazes de fundamentar a obrigação.

O que leva as pessoas a respeitar a autoridade: o interesse ou a moral? A autoridade somente surge se ela for capaz de ser respeitada, se os seus ditames forem uma extensão da moralidade dos indivíduos. O que raz afirma é que essa extensão se completa se identifica com razoes de segunda ordem, que fundamentam a autoridade e explicam ou fornecessem razoes aos seres autônomos trocarem as suas razoes pela razao juridica.

No fundo Raz pressupõe que autoridade do direito depende de uma pretensão do direito de ter uma legitimidade moral. Ele pressupõe a pergunta se é bom ou não seguir os preceitos da autoridade. 
Tal explicação não é isenta de criticas. Coleman diz que há uma ambiguidade: descrição ou normativismo. O que caracteriza a autoridade do direito é ser moralmente legitima, o que fundamenta a substituição da autonomia pela heteronomia.

Raz vem a desenvolver a "normal justification thesis"("normal justification condition") ${ }^{82}$ a qual afirma que a melhor maneira de entender e justificar a legitimidade de um comando advindo da autoridade é que os individuos estarão melhores em obedecer do que arcarem com o custo de deliberar sobre as suas próprias razoes. Tal opção advem de uma pratica racional $^{83}$.

A tese da justificação normal ilustra a substiuiçao da heteronomia pela autonomia. Essa questao racionalidade da escolha pela heteronomia esta na base da justificação do estado a partir da era moderna e coincide com a própria entrada da teoria política na modernidade

Importa registrar em consonância a que vem sendo comumente escrito ${ }^{84}$, Joseph Raz é um liberal pouco ortodoxo, na medida em que dá acento fundamental ao papel da autonomia como aspecto valorativo fundante da coletividade e do próprio direito. Autonomia que é a capacidade de escolha refletida das razoes de ação. Somente a autonomia garante a vida plena. Nesse sentido, o esforço é a construção de instituições que garantam a efetividade desse projeto.

$\mathrm{Na}$ base do direito e do seu entendimento e da determinação da relação entre direito e moral está um projeto político, um esforço de construção das bases da convivência. Isso implica na resolução da tensão entre autonomia e heteronomia na base da edificação do que é o próprio direito.

O projeto raziano permite observar a velha dicotomia entre direito positivo e direito natural não mais como a oposição entre o positivismo juridico e o jusnaturalismo. A determinação de quais são os valores morais valiosos e fundamentais que estruturam a sociedade, edificam a instituição, fundamenta a autoridade e fornece os princípios operativos para a decidiblidade dos conflitos está na raiz do que o direito é e deve ser. A dicotomia entre direito natural e direito positivo se estrutura, tendo em vista o debate contemporâneo e a

\footnotetext{
${ }^{82}$ RAZ, Joseph.Between authority and interpretation: on the theory of law and political Reason. Oxford/New York: Oxford University Press, 2009, 137.

${ }^{83}$ Raz complementa dizendo que a legitimidade da autoridade é fragmetaria, no sentido em que a extensão da autoridade do governo varia de individuo para individuo. Isso significa que as diretivas das autoridades podem ser legitimas ou não, dependendo das concepções valorativas dos indivíduos. Nesse momento é que a tese da justificação normal exerce a sua "operatividade", substituindo as razoes dos destinatários. RAZ, Joseph.A moralidade da liberdade. Rio de Janeiro: Campus, 2011, p. 52.

${ }^{84}$ GEORGE, Robert. The unorthodox liberalism of Joseph Raz. The Review of Politics, vol 53, $\mathrm{n}^{\circ} 4$
} 
emergência de uma nova gramática de direitos, sintetiza-se na questao sobre o fundamento da autoridade, na resolução da tensão entre autonomia e heteronomia.

Nesse sentido, o esforço dos teóricos da modernidade de construção da esturutra de valores sobre as quais serão edificadas as instituições e se fundamentara a autoridade tem muito em comum com a agenda contemporânea da filosofia do direito, marcada na oposição entre os interpretativistas e os positivistas.

\subsection{Autoridade e o debate da modernidade}

Segundo Norberto Bobbio, o problema fundamental da política na passagem para século XIX era construir um espaço político onde o poder fosse limitado ${ }^{85}$. O Estado nasce com a vocaçao para o poder absoluto.

O principal fenômeno sócio-politico da modernidade é o surgimento da noção de Soberania, que encontrou em Jean Bodin o seu primeiro teórico de peso ${ }^{86}$. A sociedade medieval era pluralista, marcada pela existencia de diferente fontes jurídicas desarticuladas. As Monarquias Absolutistas vieram a substituir a pluralidade e se estruturar em torno da noção de que em determinado território há um poder superior que não encontra rival (potestas superiorem non recognoscens).

No plano sociológico, o que ocorreu foi o incio de uma intensa complexificaçao das estruturas sociais que acabaram originando esferas distintas de racionalidade. Como já foi apontado, a moralidade foi progressivamente se diferenciando da política e do direito.

Num primeiro momento, num ambiente de muita incerteza, guerras e conflitos, em que a autoridade da igreja entre em declínio, é preciso encontrar novas fontes de legitimação do poder político. Concomitantemente, redobra-se o esforço de identificação do que é o direito. esta é a raiz da tentativa da aplicação do método more geométrico para a determinação da moralidade.

Em todos os seus modelos, o jusnaturalismo é apresentado como um dualismo, isto é, há dois direitos em correlação hierárquica. Esse acento hierarquizante encontra novo modo de

\footnotetext{
${ }^{85}$ BOBBIO, Norberto. Direito e Estado no Pensamento de Emmanuel Kant. São Paulo: Editora Mandarim, 2000 , p. 17.

${ }^{86}$ DALLARI, Dalmo, $\mathrm{p}$.
} 
articulação na Idade Moderna, com o surgimento da doutrina jusnaturalista como ordenação racional $^{87}$.

Como já foi explicado, a escola do direito natural racional aspira a criaçao de um sistema logico-dedutivo. A partir da natureza humana, derivariam-se as regras jurídicas.

A mensagem passada pelos pensadores do seculo XVII é que a razao tinha função fundamental porque ela permite identificar o que é justo num mundo pautado pelo ceticismo diante de qualquer concepçao moral.

Se já há um desacordo moral que impede a certeza, é preciso um esforço para superar esse estado de coisas e possibilitar a convivência - a convivência ordenada. Os homens devem pautar a sua vida pelo direito, e a sua autoridade, isto é, sua capacidade normativa de influenciar o comportamento está na possibilide real de os homens, aplicando a razão, de identificar o que é justo, o certo e o correto.

O que se observa, então, são dois movimentos que convergem para a estruturação da comunidade política. o movimento de cetralizaçao do poder real é acompanhado pelo esforço de encontro do direito natural a partir da razao. A quem eu devo obedecer: aos ditames positivos provenientes das fontes de poder institucionalizadas ou ao direito que eu alcanço por meio da razao? o que é importante registrar é que os dois movimentos se unificam no esforço de dominar um mundo conturbado e ameaçador e estruturar a política a partir de novas concepções que despontavam com o desaparecimento da ordem medieval.

Para a identificação dos elementos que apontavam para uma nova concepçao de política e que motivaram os pensadores a sistematiza-la e até mesmo estrutura-la sob novas bases, é importante observar a inversão histórica do relacionamento do homem com a sociedade.

A Antiguidade via a política como espaço para a plena realização dos indivíduos. Conforme explica Norberto Bobbio ${ }^{88}$, a sociedade nattural originaria era a família, que à época era uma forma histórico-cultural pautada pelo primado da sobrevivência. A família não era uma instituição afetiva, como nos dias atuais. Era concebida mesmo como estado prépolitico, cuja tendência inata era o movimento em direção à formação da Polis. A família era uma unidade produtiva, pautada pela desigualdade entre as pessoas. A hierarquia era a sua tônica. O desenvolvimento da família em direção ao Estado não se dava por convenção, era natural.

\footnotetext{
${ }^{87}$ FERRAZ Jr., Tercio Sampaio. Idem, $p$.

${ }^{88}$ Thomas Hobbes, p. 6.
} 
Assim, o lugar da liberdade era a Polis, em contraposição com o reino da necessidade representada pela família. Liberdade era relacionar-se entre os iguais, conviver e deliberar sobre os rumos da política, concebida numa dimensão normativa.

A modernidade assiste a alteração dessa situação, uma vez que o reino privado tornou-se o espaço da liberdade e a política, perdendo a eticidade que a caracterizava, tornouse o espaço da técnica e da efetivação de finalidades postas pelos desafios cotidianos ${ }^{89}$.

A politica começa a ser vista como uma estrutura com finalidades especificas e naõ mais como instancia unida com a moralidade. A ideia de sistema perpassa toda a sua estrutura, que se volta a proteção dos interesses individuais. O reino da liberdade é o da autonomia privada.

Exatamente por isso, o direito é ainda uma ordem objetiva, mas decorrente do homem. Existe a justiça, mas ela é ditada pela razao humana. Assim, como foi mencionado, a estrutura social deveria servir aos interesses individuais.

O pensamento hobbesiano surge então como paradigma dos novos ditames valorativos, da nova concepçao de mundo e dos novos elementos que forjavam o solo comum das esperanças e receios daqueles tempos.

Dado o caráter instrumental dessa nova concepçao de política, da emergência de uma nova visão do homem, capaz de construir mundos e deduzir a moralidade utilizando a razão, a esfera dos interesses articula a relação próxima entre direitos naturais racionais e direitos subjetivos. É possível ao homem compreender o que é certo e o correto, refletir sobre a justiça intrínseca das instancias de poder, bem como, ao entender os parâmetros da convivência.

Tendo em vista toda essa discussão, em que as fronteiras dos domínios do juridico, político e moral se dissolvem diante da complexidade do debate contemporâneo envolvendo a relação entre direito e moral, motiva o esforço de visitas a textos e discursos da modernidade, particularmente o de Thomas Hobbes, cuja obra é considerado um marco da edificação racional da política.

A leitura realizada, permite afirmar que a pergunta que estabeleceu o pensamento de Hobbes, permanece extremamente atual, dada a natureza do problema que construiu envolvendo a busca pelo fundamento da autoridade: sob qual justificativa devemos obedecer os mandamentos do poder ainda que eles nos pareceram injustos?

\footnotetext{
${ }^{89}$ Para uma analise sofisticada desse processo consultar FERRAZ Jr., Tercio Sampaio.Introduçao ao Estudo do Direito, p. 22.
} 


\section{Capítulo 2 - Hobbes e o conceito de direito}

Thomas Hobbes é conhecido pelo epíteto de teórico do absolutismo, ao lado de autores como Nicolau Maquiavel (1469-1527), Jean Bodin (1529-1596), Hugo Grócio (15831645) e Jacques Bossuet (1627-1704) a exaltação dos benefícios da estruturação do poder político a partir de uma monarquia hereditária, sem limitações de qualquer tipo ${ }^{90} \mathrm{e}$ irresponsável compõe a face mais conhecida e sinistra de uma versão do seu pensamento. Menos do que ocorreu com Maquiavel, que gerou o adjetivo maquiavélico, como sinal de atitude inescrupulosa, traiçoeira ${ }^{91}$, a caricatura do pensamento de Thomas Hobbes é tão

\footnotetext{
${ }^{90} \mathrm{O}$ Absolutismo é a forma política associada ao chamado Antigo Regime, que designa toda a estrutura política, econômica, social e cultural europeia que fora derrubada pelos movimentos revolucionários levados a cabo pela nova classe em ascensão, a burguesia. O conceito de absolutismo é complexo, encerrando diferentes concepções ao sabor de escolhas valorativas, justificadas ou não, por teóricos que se debruçaram sobre o tema. De forma bem simplificada, essa configuração política é entendida como etapa do processo de formação do capitalismo. Assim, sua causa fundamental é econômica. Ao longo do processo de desagregação da sociedade feudal, lentamente se desencadeou a concentração de poderes nas mãos do rei, fazendo que a monarquia absolutista, hereditária e eterna seja o regime que sintetiza aquele momento político, entendido eminentemente como uma transição. Assim, o rei incorpora o poder, impossibilitando a diferenciação entre espaço publico e privado; poder este qualificado como absoluto e o monarca soberano. A soberania é então o tipo de poder que identifica o regime e qualifica o rei, o que rompe definitivamente com a concepção medieval de autoridade. A força da imagem de absolutismo ocasiona exageros. O rei francês Luís XIV tornou-se o símbolo de todo o período e sua atuação política retrata a convergência entre a fortuna e a virtú. Sua autoridade incontestável faz com que sua palavra seja a lei. Porém, o contato mais próximo com a história do período mostra que tal poder não era exatamente ilimitado. Havia considerações, ponderações que o monarca deveria fazer, não somente para o alcance de fins políticos, como também em virtude de pressão por obrigações de diferentes naturezas. Mais do que isso, o chamado Antigo Regime se traduzia num complexo jogo que impunha a classe privilegiada um estilo de vida quase claustrofóbico. De certa forma, este é o mote da biografia de Maria Antonieta escrita por Antonia Fraser (Antonia Frase, Marie Antoniette, the journey, New York: Doubleday), a qual descaracteriza a vilania da rainha, retratando-a, principalmente, como mais uma vítima das regras e costumes tácitos da Corte francesa, ou seja, de um mundo derrubado pelas revoluções e que hoje soa como um testemunho da irracionalidade que o Iluminismo pretendeu aniquilar. Há notáveis nuances na atmosfera do Antigo Regime que não permite tomar o sentido de absolutismo sem exageros, pois, mais uma vez, é preciso se perguntar, por exemplo, se um rei poderia modificar as regras tacitas e tradicionais de sucessão? A tradição exerce um enorme papel enquanto regras que limitam o soberano e lhe dão legitimidade. Ver Renato Janine Ribeiro, A etiqueta no Antigo Regime: do sangue à doce vida, Editora Brasiliense, 1983.

91 "Maquiavel e maquiavelismo são adjetivo e substantivo que estão tanto no discurso erudito, no debate político, quanto na fala do dia-a-dia. Seu uso extrapola o mundo da política e habita sem nenhuma cerimônia o universo das relações privadas. Em qualquer de suas acepções, porém, o maquiavelismo está associado à ideia de perfídia, a um procedimento astuto, velhaco, traiçoeiro." Maria Tereza Sadek, "Nicolau Maquiavel: o cidadão sem fortuna, o intelectual de virtù", In: Francisco Weffort, Os Clássicos da Política, p. 13. Nesse bemsucedido ensaio introdutório, a autora realizou interessante escolha ao compor o título, o qual parece ironizar a biografia de Maquiavel e sua expressão de defensor do absolutismo. É usual tomar a Revolução Francesa como o símbolo máximo do movimento em prol da cidadania, ainda que restrita. É na passagem do século XVIII ao XIX que o súdito dá lugar ao cidadão, detentor de direitos baseado em noção de igualdade fundamental entre os homens. $\mathrm{O}$ apelo à universalidade talvez seja a marca mais importante da Revolução Francesa, que a diferencia das demais Revoluções Burguesas. Cf. Dalmo Dallari, Elementos de Teoria Geral do Estado. Maquiavel é tema de uma reviravolta importante nesse entendimento, que realça a época como um ambiente de alta sofisticação e apelo pela liberdade, aquela que se identifica a um ideário chamado de republicanismo cívico. Cf. Newton Bignotto, Maquiavel Republicano, passim.
} 
corrente que o epíteto Monstro de Malmesbury ${ }^{92}$ tornou-se de qualquer forma fiel para caracterizá-la.

A maneira depreciativa de se referir às ideias de Hobbes tem longa data, ainda que por motivos diferentes. A publicação da sua obra máxima ${ }^{93}$ de Hobbes em 1651 foi responsável pela má-fama entre os seus contemporâneos. Com o Leviatã ${ }^{94}$, Hobbes fora acusado a um só tempo de traidor e herege ${ }^{95}$. Hobbes ganhou a inimizade de pessoas com quem compartilhou seu tempo de exílio, justamente porque foi considerado um detrator da monarquia que seria restaurada em 1660. Assim, o Hobbes absolutista de hoje fora o traidor da realeza de ontem.

\footnotetext{
${ }^{92} \mathrm{O}$ impacto do livro Leviatã, escrito em inglês, durante a estadia de Hobbes na França, marcou definitivamente a cultura britânica. Segundo Richard Tuck, nenhuma obra em filosofia havia sido escrita ainda em inglês até aquele momento. Apesar da importância de Leviatã, ainda segundo Richard Tuck, não havia ainda uma edição acurada do livro. Portanto, a edição da Cambridge University Press elaborada pelo próprio Tuck, de 1996, é de extrema relevância, ainda que, conforme o próprio editor salienta, não seja completa. Noel Malcolm, grande estudioso do hobbesianismo, foi o responsável por uma série de textos editados pela Oxford University Press. Essa coletânea, cujo marco inicial foi a publicação de De Cive, tanto em latim como em inglês, em 1993, recebeu, em julho de 2012,mais um título, a edição de Leviathan elaborada por Noel Malcolm. Esta edição possui 1732 páginas e contem os textos integrais em inglês e em latim.

${ }_{93}$ O Leviatã tornou-se o símbolo do pensamento de Hobbes, mas há duvidas se o autor tomava o livro desse modo. Segundo Richard Tuck, o projeto hobbesiano era principalmente se posicionar nas discussões cientificas da época, que estavam em processo de enorme transformação desde que Galileo Galileu lançou Discurso sobre os dois sistemas de mundo, em 1632. "Hobbes dedicou ao menos metade de sua vida e de sua energia à tentativa de compreender a ciência moderna, no momento em que ela dava seus primeiros balbucios; seu entendimento da ciencia moderna foi por certo tão percuciente quanto o de seus contemporâneos; contudo, como suas ideias a esse respeito não são plenamente discutidas no Leviatã, suas teorias não são levadas em conta. As obras nas quais ele registrou essas ideias mal são lidas hoje, e algumas nem sequer foram traduzidas do original latino. Ainda que o Leviatã seja notável em muitos aspectos, Hobbes não pretendia que ele fosse o corpo principal de suas ideias mesmo em questões políticas e morais, e nossa (compreensivel) concentração exclusiva nessa obra distorceu muitos relatos daquilo que ele se empenhava em fazer". Richard Tuck, Hobbes, p. 10. Outros, corroborando a importância relativa de Leviatã, afirmam que o fato deste livro ter sido escrito em inglês já diz muito sobre as intenções de Hobbes, uma vez que a cultura letrada da época impunha o latim. Nesse sentido, De Cive, originalmente em latim, voltava-se para os eruditos, enquanto o Leviatã, para um público mais amplo. De fato, é mesmo relevante em todos os ambitos se apoiar principalmente na autocomprensão do autor? Independentemente do fato de Hobbes olhar a si mesmo como um cientista natural o Leviatã é o projeto por excelência da Ética na Idade moderna. Descartes, um grande símbolo do período, não escrevera uma Ética, embora a tivesse planejado. Galileu, outro expoente, se destacou pelo seu esquema de ciências. Os pensadores da primeira metade do século XVII reunidos no círculo de Mersenne assumiam como tarefa de principal importância o estabelecimento de uma nova ciência natural, deixando em segundo plano a ciência moral e política, projeto que Hobbes desenvolveu principalmente motivado pelo trabalho de Hugo Grócio e também pelos acontecimentos políticos de seu tempo.

${ }^{94}$ Ao mesmo tempo em que esta obra mostrou-se de importância ímpar, iniciou-se também uma série de debates e divergências que se agregaram à sua herança. Um dos debates mais importantes, e que de certa forma simboliza uma época de guerras de religião, se refere á atuação política do corpo eclesiástico. Hobbes foi considerado um herege pela ênfase ao poder secular do soberano, que subordinaria inclusive o poder espiritual da igreja. Cf. Noel Malcolm, Biography, Cambridge Companion to Hobbes.

${ }^{95}$ Durante os séculos XVII e XVIII a visão era de que Hobbes fora um ateu: "Assim, a primeira dúvida diz respeito aos comentadores, à fortuna crítica de Hobbes, ao modo pelo qual se constituiu uma imagem dele que desconsidera sua religião. Essa imagem chegou ao ponto de dizê-lo ateu, naquela que foi uma leitura bastante corrente do século 17 ao 19". Renato Janine Ribeiro, "um filósofo que tinha religião", Ribeiro, R. J., doc 284, Biblioteca Florestan Fernandes, FFLCH, USP, disponível também em versão digital (http://www.renatojanine.pro.br/prefacios/thamy.html), consulta em 14 de maio de 2011.
} 
A recepção das ideias de Hobbes mostra a profunda divergência que sempre as envolveram, o que no entanto não impediu que assumissem a forma de um ideário difuso e distorcido e com grande ressonância. Como no passado ${ }^{96}$, é possível taxar essa doutrina distorcida como hobbismo ${ }^{97}$, denominação que identifica um conjunto de opiniões articuladas e que servem como um produto odioso a ser combatido; muito mais uma peça ideológica, uma caricatura que serve como signo da negação, como guia do que não fazer, em vez de se traduzir em retrato aceitável da filosofia ética e política de Hobbes ${ }^{98}$.

Há grande dose de improvisação e pressa na identificação e exposição de uma tradição interpretativa que qualifica Hobbes como um autoritário. Ao fazê-lo, não se pensa nas grandes leituras, aquelas que pavimentaram o caminho por onde trilharam os campos semânticos das pesquisas importantes e os quais, de certa forma, ultrapassam os muros acadêmicos. De uma obra com tantos séculos, registrar as suas grandes fontes interpretativas é tarefa temerária, sem dúvida. Ao correr esse risco, pensa-se apenas em distinguir alguns dos eminentes pensadores que se destacaram no esforço de elucidação de uma obra universal.

A obra Hobbes Studies, de C. K. Brown, reúne alguns textos elaborados por destacados schollars. Um deles é C. B. Machperson, autor de A teoria político do individualismo possessivo ${ }^{99}$.

O livro também destaca e discute teses consagradas. A chamada Tese de Taylor $^{100}$ é exemplar no que toca à demonstração da complexidade que o pensamento de Hobbes enseja.

É quase unanime o conhecimento e a aceitação do famoso argumento de David HUme segundo o qual não se pode estabelecer uma conexão lógica entre um discurso descritivo e um prescritivo.

Uma das facetas mais incríveis da filosofia do direito contemporânea está na critica a esse postulado estruturante da concepção normativa e obrigatória do direito, realizado por

\footnotetext{
${ }^{96}$ Como ler um texto filosófico? Como se debruçar sobre um autor do passado à luz de problemas presentes? Como transportar soluções cobertas pela poeira histórica a um tempo impossível de ser imaginado por quem viveu séculos atrás? Como fugir do anacronismo, isto é, não incorrer em equívocos que hoje soam como um primário despreparo? desenvolver artigo do orlando

${ }^{97}$ Stearling P. Lamprecht, "Hobbes and Hobbism", The American Political Science Review

${ }^{98}$ Quentin Skinner adota a teoria do hobbismo, mas com diferenças importantes. Se alude a atitude depreciativa de livros de referencias e outros manuais que "demonizam"o autor rotulando-o com termos em conotação pejorativa. Tais autores não querem explicar Hobbbes e sim utiliza-lo como espantalho para defender suas teses. Um exemplo significativo dessa postura é o de Sheldon Wolin, autor de Politics and vision. O autor faz criticas instigantes ao modelo político hobbesiano, sustentando, por exemplo, a impossibilidade lógica do estado de natureza. O maior problema é o estilo utilizado pelo autor, carregado de ironias, ataques, levando o seu leitor a imaginar que Hobbes defende uma tese irracional.

${ }_{99}$ Uma interessante utilização dessa interpretação é encontrado no livro de Norberto Bobbio sobre Thomas Hobbes (BOBBIO, Norberto.Thomas Hobbes. Rio de Janeiro: Campus, 1991.

${ }^{100}$ Segundo Renato Janine Ribeiro, a tese de Taylor é muito pouco estudada entre nós. Cf. Renato Janine Ribeiro, Um filosofo que tinha religião
} 
filósofos do calibre de John Searle ${ }^{101}$. Ainda assim, a importância de David Hume pode ser percebida, nem precisaria dizer, na obra de Hans Kelsen, até porque o ataque de Searle parece ainda pouco convincente ${ }^{102}$.

A teoria hobbesiana é descritiva ou normativa?

Segundo Michael Oakeshott ${ }^{103}$ as famosas leis da natureza hobbesianas não tem aspecto normativo, são antes máximas de prudência que aconselham e não prescrevem comportamento.

Segundo A. E. Taylor ${ }^{104}$, a ética hobbesiana antecipa as elaborações de Kant. Nesse sentido, a tese de Taylor vai de encontra a uma enorme tradição que afirma estar o homem no estado de natureza agindo segundo uma razao instrumental.

Antes propriamente dos percursos destacados, Ferdinand Tonnies, Meineccke, Sir Mollesmorth e watckins são responsáveis pela grande importância que Hobbes e a doutrina contratualista assumiu no século XX, após período de descrédito no século anterior, dominado pelo "elogio da história",105.

Mesmo em autores contemporâneos como Jean Hampton e David Gauthier ainda se observa a grande influencia desse pensamneto político hobbessiano corrente.

Destaca-se ainda Michael Oakeshott, responsável pela organização e edição de obras do Leviatã, o grande professor sem duvida tornou-se um dos principais comentadores de Hobbes no século XX

Fora Leo Strauss, indubitavelmente, quem conferiu a obra de Hobbes um grande sopro de renovação. Foi Strauss quem procurou enfatizar os traços humanistas de Hobbes, mais do que suas pretensões cientificas. Segundo Strauss, a teoria política e moral de Hobbes não forma um todo, como de indicio se pensava, ligando-se muito mais à concepções formadas numa etapa anterior da vida de Hobbes, quando ela ainda não havia visitado o circulo de Marsenne na França e se estimulado a se debruçar nos grandes temas filósofos de sua época.

Após esse período de grande fertilidade, a influencia decisiva dos estudos de historia intelectual inglesa e da emergência de um novo paradigma de estudos e fundamentação da liberdade, que se denomina largamente como republicanismo, os estudos de Hobbes

\footnotetext{
101 "How to derive ought from is", Philosophical Review, LXXIII, No 1, Jan, 1964.

102 Consultar Judith Thomson, "How Not to derive ought from is", The American Political Science Review, No4, October, 1964.

${ }^{103}$ Michael Oakeshott, Introduction, Leviathan, 1960.

104 "the Ethical Doctrine of Hobbes", Hobbes Studies, p 35.

${ }^{105} \mathrm{O}$ argumento contratualista perdeu o seu prestigio no século XIX. Conforme salienta Renato Janine Ribeiro, Hobbes: o medo e a esperança, In: Francisco Weffort, Os Classicos da Política
} 
formaram um caldo complexo, diversificado e de grande fertilidade o que desmente aqueles que consideram terminada que qualquer interpretação ou comentário a ser feito sobre Hobbes é excedente.

Nesse sentido, citar autores é certamente cometer injustiças. Correndo esse risco, destaca-se Noel Tom Sorell, Pocock, Taylor, Renato Janine Ribeiro, Richard Tuck e Quentin Skinner

Há uma grande senda formada por Warrender que procurou dar ênfase a temas não tão estudados como a teologia hobbesiana. O mérito de Warrender foi perscrutar uma nova lógica ao aspecto multifacetado do Leviatã, organizando-o tematicamente a partir das preocupações religiosas de Hobbes. Trata-se de uma guinada interpretativa, alicerçando os temas políticos, morais, jurídicos e econômicos a partir do problema da fé.

Traça-se, agora, uma descrição da doutrina autoritária ${ }^{106}$ na sua versão hobbesiana, visando formar um cenário de negação, isto é, de pontos que identificariam as preocupações, intenções e propósitos de Thomas Hobbes, mas que constituiriam antes distorções, as quais serão identificadas e superadas ${ }^{107}$, servindo, portanto, como um instrumental organizador, um roteiro de exposição do pensamento do autor e das suas projeções no problema discutido diretamente nesse trabalho - a questão da autoridade e o conceito de direito (como práticas sociais especificas e arbitragem) em Thomas Hobbes.

Aludiu-se ao hobbismo, como símbolo do conjunto de interpretações negativas da obra de Hobbes, e (independentemente do fato do termo já ter o seu realce no século XVII) de sua força, insurgindo-se como versão tradicional e definitiva. É notório que as transformações históricas da época, as grandes navegações, o descobrimento de novos continentes, o contato com diferentes civilizações, a descoberta do "outro"108 impactaram profundamente os escritos políticos da época ${ }^{109}$. O mesmo ocorreu com o projeto $^{110}$ de Hobbes. Sua obra máxima, o

\footnotetext{
${ }^{106}$ Imaginei, de início, chama-la de imperativista. Porém, dada a centralidade da política na filosofia hobbesiana, entendi que autoritária ou autoritarismo, como sinônimos de hobbismo, é termo que se alinha mais ao cerne do pensamento geral de Hobbes.

${ }^{107}$ Essa "estratégia" foi inspirada em diversos textos introdutórios ao pensamento de Hobbes, entre os quais se destacam Maria Izabel Limongi, Hobbes, e Renato Janine Ribeiro, em seu ensaio para a coleção Os Clássicos da Política organizado por Francisco Weffort.

${ }^{108}$ Para uma descrição desses acontecimentos e a sua relação com a teoria jurídica, v. Jose Reinaldo de Lima Lopes, $O$ direito na historia.

${ }^{109}$ Bronoxski, Mazlish, A tradição intelectual do Ocidente, p. 207 e ss..

${ }^{110}$ A história da composição da obra de Hobbes é extensa e complicada. Richard Tuck passa grande parte de seu pequeno livro sobre Hobbes fazendo esse relato relacionando fatos a sentidos, motivos e justificativas. Por exemplo, por que a primeira obra política de Hobbes, escrita em inglês, repetia em grande parte o que Hobbes havia escrito em latim correspondente a seção dois e três de seu Elementos de Filosofia, obra concebida como tratado geral e sistemático de toda a sua filosofia? Outra questão é respondida por Richard Tuck na seção dois de sua introdução ao Leviatã, o que mostra o trabalho de contar a historia à luz de problemas conceituais: Hobbes
} 
Leviatã $^{111}$, tem como subtítulo Discurso sobre o governo civil e eclesiástico, mostrando a sua preocupação em tratar o tema das guerras religiosas, principal responsável pelo amplo desenvolvimento da teoria política na época ${ }^{112}$ e da interferência do corpo eclesiástico no governo civil. Muito além das circunstancias especificas do tempo, as quais impunham esforço de resolução, o pensamento de Hobbes situa-se no panteão de grandes obras da humanidade e, portanto, sendo um clássico, possui projeção universal.

O hobbismo já incorpora o vernáculo inglês ${ }^{113}$. Segundo o The American Heritage Dictionary of the English Language ${ }^{114}$ significa uma teoria política elaborada por Thomas Hobbes a qual defende a monarquia absoluta como forma de defesa de uma sociedade estável $^{115}$. Já o Collins English Dictionary ${ }^{116}$, identifica hobbismo como a filosofia política de Hobbes, de índole mecanicista e que mostra uma preocupação com a necessidade de um soberano todo poderoso para controlar os seres humanos.

Como se vê, o termo incorpora uma visão estereotipada e que mais confunde do que auxilia aqueles que buscam entender a obra de Hobbes. Sendo assim, o primeiro obstáculo é

escrevera Leviatã para agradar os republicanos? A historia do Leviatã mostra que durante a redação Hobbes não sabia ainda o resultado da guerra civil

${ }^{111}$ Segundo Richard Tuck, a importância de $O$ Leviatã é difícil de dimensionar. Por meio desse livro, que simboliza todo o conjunto de pensamento hobbesiano, houve uma tranformaçao intelectual na Inglaterra. Hobbes instaurou a situação onde não havia campo do conhecimento não abrangido por obras em língua inglesa. Mais do que isso, Hobbes criou a filosofia em língua inglesa, lembrando que à época os debates eram realizados principalmente em latim. Mas o que significa dizer que a filosofia em língua inglesa foi inventada por Hobbes? Qual é a concepção de filosofia em sua época? Talvez muito diferente da nossa. É importante frisar que Hobbes não vivia uma vida voltada ao crescimento do conhecimento per se. Ele, como foi mencionado, fora secretario particular de homens de grande fortuna e, nessa condição, era incumbido (heteronomamente) por tarefas determinadas por seus patrões. Alem disso, Hobbes viveu fora do ambiente universitário, assim como Descartes (há importantes implicações desse fato). Não havia uma função social, tal como se tem hoje, denominada filosofo, embora isso tenha que ser levado com ressalvas (é só observar a vida de Samuel Pufendorf). Essa reflexão visa salientar a grande gama de questões carecedoras de respostas, bem como a absoluta necessidade de não encarar qualquer declaração como definitiva, pois seu sentido ainda está por se construir. Apenas para ilustrar o que foi dito, Hobbes afirma que sua teoria não encontra respaldo no que é ensinado nas universidades de sua época, contaminada pelo que ele denomina influencia de Aristoteles, ou seja, a filosofia escolástica: "But the Philosophy-schooles, through all the Univesities of Christendome, grounded upon certain Texts of Aristotle, teach another doctrine." Leviathan, p. 16. Assim como Hobbes, Descartes também produzira sua obra fora do "circuito universitário": "É preciso algum esclarescimento sobre essa obra, antes de apresenta-la, ainda que de forma geral. A primeira observação diz respeito ao fato de a filosofia de Descartes ter sido desenvolvida fora das universidades, isto é, paralelamente ao ensino institucional da filosofia. À filosofia de sua época, Descartes aplicava o titulo de filosofia das escolas, certamente referindo-se à filosofia escolástica, que ainda era ensinada e praticada nas universidades europeias do seculo 17. Muito das suas investigações devem ser entendidas como uma critica a espírito dessa filosofia institucional, que ele não praticou. Por isso, uma parte significativa da obra de Descartes está dispersa soba a forma de correspondências, de uma serie de cartas enviadas e recebidas entre seus interlocutores dentro e fora das universidades." Paulo Vieira Neto, "Descartes e o método da filosofia”, p. 86 In Vinicius de Figueiredo (org), Seis filósofos na sala de aula, Berlendis \& Bertecchia Editores. ${ }_{112}$ Idem, p. 207.

${ }^{113}$ Pretende-se, de forma muito sintética, traçar uma definição lexical de hobbismo, enfatizando que seu termo já é corrente.

${ }^{114}$ The American Heritage Dictionary of the English Language, Fourth Edition, 2000

${ }^{115}$ Disponível em www.thefreedictionary.com;Hobbism, acessado em 15 de julho de 2012.

${ }^{116}$ Collins English Dictionary, Complete and unabridged, Harpers Collins Publishers, 2003 
superar os entraves produzidos pelas distorções por mais complicado que isso seja. A dificuldade está na sua força, permanência e quase onipresença. Hobbes é considerado um precursor do positivismo jurídico ${ }^{117}$. A esse elemento, somam-se as facetas de um Hobbes materialista, autoritário e absolutista ${ }^{118}$.

Como já se assinalou, a obra-prima de Thomas Hobbes, o Leviatã ${ }^{119}$, foi escrito num tempo $^{120}$ de grande turbulência política ${ }^{121}$, que culminou em guerra civil. Sua vida foi marcada pelo signo da guerra. Conta-se ${ }^{122}$ que a mãe do pensador entrou em trabalho de parto após ter recebido a notícia que a invencível armada espanhola de Felipe II rumava para a Inglaterra, como ditava a lógica mercantilista voltada à riqueza das nações, de modo que Hobbes é filho do medo, ou melhor, irmão gêmeo.

No século XVII a turbulência estava na ordem do dia. De forma geral, o século XVII foi um tempo de conflitos, marcado pela violência e extensão do evento símbolo do período, a guerra dos Trinta Anos (1618-1648), no qual convergiam vários polos de tensão, como a questão religiosa, que invadia os limites das nações, plantando a discórdia dentro das fronteiras, promovendo a desestabilização política, e a corrida mercantil entre os povos, que tinha na passagem do século XVI para o XVII, a Espanha como grande protagonista.

\footnotetext{
${ }^{117}$ Muitos autores entendem que Hobbes é um precursor do positivismo jurídico, mas o fazem sem qualquer conotação pejorativa. Cf. LAFER, Celso. Hobbes, o direito e o Estado Moderno. São Paulo: Associaçao dos advogados de São Paulo, 1980.

${ }^{118}$ Em se tratando de autores da filosofia moderna, as distorções são a tônica de reconstruções finalistas, que se servem das obras para referendar visões previamente estabelecidas. Locke, por exemplo, que tem uma imagem bem mais suavizada que Hobbes, é tido como defensor da democracia formal, da soberania do Parlamento (o que implica na luta contra o absolutismo) e de liberdades individuais, entre elas, a propriedade privada. Além disso, é considerado o pai intelectual da Revolução Americana. Seu pensamento, no entanto, não é livre de simplificações e de alvo para ataques às desigualdades.

${ }^{119}$ Traçar um breve resumo da historia do leviatã. £Tuck e Noel Malcolm

120 O século XVII pode ser considerado um tempo de profundas ebulições políticas, que marcaram profundamente uma reflexão no âmbito da política voltada a encontrar um patamar mínimo de convivência. $¥$ colocar aqui Grocio

${ }^{121}$ Thomas Hobbes passou a sua existência nesses tempos tormentosos; cresceu e viveu sob o signo da guerra. Mais: nasceu marcado por ela: repete-se exaustivamente ${ }^{121}$ na literatura secundária que seu próprio nascimento foi impulsionado pela notícia da chegada da invencível armada espanhola, de modo que Hobbes e o medo são irmãos gêmeos. " Thomas Hobbes de Malmesbury nasceu prematuramente em 05 de abril de 1588, na casa de seu pai em Westport, Inglaterra, quando sua mae recebeu assustadamente a notícia da iminente invasão da Armada Espanhola. Esse fato teria levado Hobbes a afirmar em conhecida passagem de sua autobiografia que sua mãe tinha dado luz à gêmeos, ele o medo", Thamy Pogrebinschi, "Hobbes, Thomas 1588 - 1679”, In: Vicente de Paulo Barreto, Dicionário de Filosofia do Direito, p. 436. A imagem é forte e ilustrativa, e por isso é utilizada como a chave para entender o seu pensamento: Hobbes construira uma teoria política que procuraria criar e entender um mundo onde os homens pudessem viver em paz, de modo que o ciclo da vida e o da morte não recebesse qualquer intervenção. Os homens poderiam trabalhar e ter os seus filhos sem serem atormentados pelo horizonte do medo e, principalmente, da morte violenta.

${ }^{122}$ Essa história é repetida ad nauseam em quase todos os comentadores de Hobbes, mesmo em textos filosóficos. O próprio hobbes foi quem deu origem a essa "tradiçao" ao trazê-la em sua autobiografia. Além de Thamy Pogrebinschi, já citada, fazem o mesmo Renato Janine Ribeiro...., Martinich.... tom Sorell
} 
A vida ${ }^{123}$ de Hobbes foi profundamente impactada pela agitada vida política da Inglaterra ${ }^{124}$. Por ter escrito um panfleto ${ }^{125}$ voltado a intervir diretamente nos acontecimentos de seu tempo ${ }^{126}$, Hobbes exilou-se na França e de lá assistiu à débâcle do rei Charles I. O monarca acabou preso e decapitado pelos revoltosos, fato que chocou profundamente não somente à Hobbes mas toda a comunidade europeia ${ }^{127}$.

O trauma da guerra e do caos o guiou na composição de sua obra mais famosa. Em conhecidíssimo trecho, Hobbes expressa o temor ao terror ${ }^{128}$; para tanto, cria e descreve a vida de plena igualdade do estado de natureza ${ }^{129}$ :

${ }^{123}$ Este é um trabalho de filosofia do direito. Poderia se esperar, portanto, a adoção de um método que a legitimasse como tal, aquele que de certa forma tornou-se hegemônico e sinônimo de filosofia no Brasil: o método estrutural de leitura. Cf. Ronaldo Porto Macedo, "metodo estrutural de leitura" ref. Como se vê, no entanto, a dissertação se utiliza amplamente de obras de historia das ideias, das quais recebe grande influência. Richard Tuck, como que se quisesse avisar o seu leitor do peso que a abordagem histórica iria desempenhar em sua versão do pensamento de Hobbes, cita um trecho de Os Elementos da Lei Natural e Política: "Ainda que as palavras sejam os signos que temos das opiniões e intenções alheias, não obstante, como sua equivocidade é muito frequente, de acordo com a diversidade da contextura e dos elementos que as acompanham (de que a presença daquele que fala, a nossa visão de suas ações e a conjetura sobre suas intenções têm de nos ajudar a desincumbir), é por certo extremamente difícil compreender as opiniões e os sentidos de homens que há muito nos deixaram, e de cuja significação nos legaram somente seus livros; livros que não podem ser entendidos sem suficiente conhecimento de história para se desvendarem as circunstancias supramencionadas, nem, do mesmo modo, sem uma grande prudência no observá-las" apud Richard Tuck, Hobbes, p. 5. Um dos maiores interpretes de Hobbes, Renato Janine Ribeiro, de maneira franca e crítica assume a influencia da história das ideias, tratando de registra-la e correlacioná-la com a ideia de filosofia em posfácio da sua obra mais importante. Renato Janine Ribeiro, Ao leitor, sem medo, ref.

${ }^{124}$ A famosa rainha Isabel, que não deixou herdeiros, foi considerada excepcionalmente hábil por conseguir dar à ilha certa estabilidade, além de ter realizado intervenções econômicas que garantiriam a Inglaterra grande crescimento econômico que a habilitaria a ser o pais líder das nações, sendo palco para a Revoluçao Industrial no século XVIII (embora mesmo a sua época as finanças reais estivessem em situação alarmante, fato que se agravou no século seguinte nos reinados de Jaime I e Carlos I). As razoes da estabilidade ainda hoje são discutidas, porem Elisabeth I conseguiu dissolver a tensão religiosa ao "casar" protestantismo com a causa nacional. Além disso, aproveitou-se, conforme explica Frances Yates, de uma circunstancia que lhe poderia trazer problemas em vantagem pois aproveitou a sua virgindade para, simbolicamente, "casar com o povo", o que a tornou extremamente popular e a permitiu diminuir as tensões de um tempo muito tumultuoso. Cf. Renato Janine Ribeiro, "introduçao", in Thomas Hobbes, Do Cidadão, Martins Fontes, p.XXIV

125 "Hobbes escreveu os Elementos de Lei como uma espécie de programa a ser usado pelo conde e seus partidários nos debates parlamentares. Mas, quando o Parlamento Curto se reuniu, a emoção dominante de Hobbes era o medo de que o escrito pudesse ser usado contra ele em alguma futura perseguição; assim, fugiu de repente para a França em novembro de 1640, tendo ficado ali até o inverno de 1651-52, enquanto se desenrolavam as amargas campanhas da guerra civil inglesa.” Richard Tuck, Hobbes, p.40.

${ }^{126}$ Pode parecer que Hobbes, por ter a intenção de participar dos acontecimentos de seu tempo, fora um protagonista político. Não é verdade. Hobbes fora um homem sem recursos e empregado particular de nobres. $¥$ falar das razoes pelas quais hobbes se tornou um filosofo, sua orgiem pobre e que a ideia de filosofo e radiclamente diferente da de hoje

${ }^{127} \mathrm{O}$ rei Charles I foi decapitado em janeiro de 1649. Cf.

${ }^{128}$ Não deixa de ser irônico que a historia da política moderna, marcada pela guerra, tenha gerado tantas obras que objetivavam gerar novos conceitos, sistematizar as linhas gerais da política tal como ela se apresentava, bem como intervir na realidade, muitas vezes como modo de evitar o terror que foi uma das marcas mais traumáticas do período; terror o qual de certa forma assinalou o fim dessa época e a preparação para uma nova etapa. De forma geral, ver

${ }^{129}$ A ideia de estado de natureza é trazida no famoso capítulo XIII do Leviatã, mas não somente nele. Encontrase também nas duas outras versões anteriores de sua filosofia política (Do Cidadão, capítulo I, e Elementos de Lei, capitulo ). 
"Portanto, tudo aquilo que se infere de um tempo de guerra, em que todo homem é inimigo de todo homem, infere-se também do tempo durante o qual os homens vivem sem outra segurança senão a que lhes pode ser oferecida pela sua própria força e pela sua própria invenção. Numa tal condição não há lugar para o trabalho ${ }^{130}$, pois o seu futuro é incerto; consequentemente, não há cultivo da terra, nem navegação, nem uso das mercadorias que podem ser importadas pelo mar; não há construções confortáveis, nem instrumentos para mover e remover as coisas que precisam de grande força, não há conhecimento da face da Terra, nem cômputo do tempo, nem artes, nem letras; não há sociedade ${ }^{131}$; e o que é pior do que tudo, um medo contínuo e perigo de morte violenta. E a vida do homem é solitária, miserável, sórdida, brutal e curta. ${ }^{132}$

A densidade semântica, a profusão de sentimentos, a interconexão de valores e temas presentes nesse trecho salienta o compromisso central de o Leviatã com a vida. A política, enquanto invenção humana, o Estado, como produto artificial, é que torna a vida válida. Qual o valor da vida no estado de natureza? A igualdade de todos os homens cria as circunstancias para o florescimento das paixões que determinam os comportamentos belicistas, tornando a vida (e a morte) brutal; e uma vida assim não merece ser vivida.

Havia então indagações profundas sobre o fundamento do poder, sobre a interferência dos assuntos eclesiásticos nos regimes políticos, no tocante a melhor estrutura do corpo religioso, da influencia política deste e sobre a maneira de conduzir as querelas entre católicos e protestantes, que tanta discórdia haviam provocado por toda a Europa.

\footnotetext{
${ }^{130}$ Hobbes é o pai do conceito moderno de Estado. Entre os pilares desse conceito, encontra-se a ideia de que o Estado tem a finalidade de estabelecer as condições para a troca, para o comércio e para uma vida que garanta a subsistência. Em outras palavras, a ideia de mercado, já se encontra desenvolvida na teoria política hobbesiana, assim como em Maquiavel. "Thomas Hobbes é conhecido sobretudo por seu pensamento político, mais precisamente como o pai do conceito moderno de Estado. Pelo menos três ideias compõe este conceito (...); a ideia de que o Estado tem por fim regulamentar a vida econômica, isto é, garantir a industria, o comércio e todos os ingredientes de uma vida materialmente satisfeita”. Maria Izabel Limongi, p.7. Em aula ministrada pelo professor Ricardo Silva, no âmbito da disciplina Métodos históricos e teoria política (FLS-6169) oferecida pelo programa de pós-graduação do Departamento de Ciência Política da Universidade de São Paulo no primeiro semestre de 2012, foi reservado certo espaço para apresentar as relações entre as obras de Adam Smith e Thomas Hobbes, que realçava o quanto os trabalhos deste antecipavam as inovações perpetradas e desenvolvidas por Smith em sua obra fundamental A Riqueza das Nações. De certa forma, reflexos das ideias hobbesianas em pesquisas econômicas já são de longa data conhecidas. Basta observar o papel que o conceito de estado de natureza exerce ao fornecer uma hipótese geral para identificar e explicar lógica de comportamento, o que tem ampla repercussão em teorias econômicas, como se vê no "Dilema dos prisioneiros", e em outras, como teoria dos jogos e teorias da decisão racional. Cf. Tom Sorell, “Hobbes”, In: Nicholas Bunnin; E. P. Tsui-James. The Blackwell Companion to Philosophy, p. 675.

${ }^{131}$ Essa frase, solta no meio do parágrafo, sinaliza uma nova concepção de política e o engajamento que de certa forma marca uma época iconoclasta, de ruptura da força da autoridade, principalmente da de Aristóteles. No campo específico do direito, tal como salienta Bobbio, marca a ascensão da doutrina do direito natural stricto sensu, uma vez que o modelo antigo, o aristotélico-tomista, tem importância menor, sendo chamado por isso mesmo de modelo alternativo. Cf. Norberto Bobbio, Thomas Hobbes, capítulo primeiro.

${ }^{132}$ Leviatã, p.109. " (...) no Knowledge of the face of the Earth; no account of Time; no Arts; no Letters; no Society; and which is worst of all, continuall feare, and danger of violent death; And the life of man, solitary, poore, nasty, brutish, and short." Leviathan, p. 89.
} 
O que causava a guerra? Por que por em toda a parte a turbulência, o motim, a traição imperavam? Como explicar a energia com que os homens se lançavam na discussão e na luta por questões religiosas? Qual era a natureza do homem, ser que não se dispunha (aparentemente) a tratar racionalmente seus problemas? Como fazer para que se criasse espaço de discussão racional alheia e intangível as paixões que tanto promoviam a tragédia da existência ${ }^{133}$ ?

São questões que trataram de ser equacionadas por Thomas Hobbes; elementos que servem de pano de fundo a um dos mais seminais textos da história do pensamento ocidental, o famoso capítulo XIII do Leviatã ${ }^{134}$.

A causa dos conflitos ${ }^{135}$ parecia ter raízes no cerne do espírito do homem e se efetivava mediante disputas que superavam qualquer esforço de entendimento e, estando em jogo princípios e valores, muitos deles religiosos, que colocavam em cheque a noção tradicional de ser humano, como ser racional e criado a imagem e semelhança de Deus.

Nesse contexto, forma-se a doutrina aqui cunhada como hobbismo. Para tanto é preciso tomar como base a ideia de estado de natureza. Para Scott Shapiro, estado de natureza é a condição social onde não existem lei e governo, caracterizado exatamente pela situação de guerra de todos contra todos e na qual a vida seria solitária, pobre, bruta e curta.

No estado de natureza não existe um poder comum capaz de dirimir conflitos, formular leis e agir em prol dos interesses coletivos. Cada individuo é juiz, júri, executor, administrador e legislador em causa própria ${ }^{136}$.

O estado de natureza é uma situação hipotética e não uma referencia a um momento histórico vivido pelos homens. Apesar da estranha passagem no final do capitulo XIII, em que Hobbes alude a antigos povos germânicos e povos ameríndios como exemplos do estado de

\footnotetext{
${ }^{133}$ Frequentemente, na imprensa, no dia-a-dia, nas conversas comezinhas e nas mesas em que se tomam grandes decisões, as explicações sobre alguns fenômenos chocantes que impressionam a todos são tratados como expressões de irracionalismo. Tome-se, por exemplo, assassinatos de crianças pelos pais, ou o seu contrario, de filhos que vitimizam àqueles que os geraram. Quase sempre o relato desses eventos são acompanhados de manifestações de desencanto, que atestam o absurdo.A teoria hobbesiana foi construída justamente para tratar, entender e solucionar esse problema, o que mostra a sua perene atualidade.

${ }^{134}$ É no capitulo XIII que se encontra o conceito de estado de natureza, o qual, segundo Renato Janine Ribeiro forma a pedra angular da filosofia política de Thomas Hobbes. Cf. Classicos da politica

${ }^{135}$ Os conflitos, como já se mencionou, marca definitivamente a historia e a cultura da época. A cultura do renascimento tardio, na qual Hobbes fora criado, é profundamente belicista. Hobbes viveu a sua vida toda como um serviçal de nobres e, portanto, à mercê dos interesses destes. ¥contar a influencia do humanismo

${ }^{136}$ Shapiro faz uma leitura de estado de natureza que o identifica a sociedade primitiva e, assim sendo, à luz dos mais recentes conhecimenots antropológicos, tenta descaracterizar o estado de natureza criado por Hobbes. Ou seja, para Shapiro não é um modelo ideal, ele existe e existiu concretamente. Enquanto alguns críticos afirmam que Hobbes errou ao imaginar uma situação social que nunca existiu e nem tem condições de existir, Shapiro afirma que o estado de natureza existe mas não se compatibiliza com a descrição de Hobbes.SHAPIRO, Scott. Legality. Massachusetts: Cambridge University Press, 2011.
} 
natureza, a imagem do estado de natureza é de um modelo ideal típico de um laboratório de experiências cientificas.

Os homens no estado de natureza não tendem a se associar, não significa que eles sejam seres isolados, vivendo com plena liberdade e em plena solidão. Assim como há espaços para a juridicidade, há espaços para a relação entre os homens, ainda que no estado de natureza essas relações não sejam pautadas pela razao. Não existe sociedade de um determinado tipo, aquela em que existam condições especificas de sociabiliade. Como Maria Isabel Limongi defende, entre as razoes que tornam os homens inimigos uns dos outros, o que torna o estado de natureza uma situação tendencialmente belica ${ }^{137}$, está a luta pela gloria. Isso é uma critica ferrenha a sociedade cortesã, aquela existente no Antigo Regime. Nesse sentido, pode-se entender que a sociedade cortesão não era sociedade propriamente dita, pois ali existiam condições para a configuração do estado de guerra.

\section{(...) durante o tempo em que os homens vivem sem um poder comum capaz.} de os manter a todos em respeito, else se encontram naquela condiçao a que se chama guerra. Uma guerra que é de todos os homens contra todos os homens. A guerra não consiste apenas na batalha, ou no ato de lutar, mas naquele lapso de tempo durante o qual a vontade de travar batalha é suficientemente conhecida. Daí a noção de tempo deve ser levada em conta quanto à natureza da guerra, do mesmo modo que quanto à natureza do clima. Tal como a natureza do mau tempo não conistem em dois ou três chuviscos, mas numa tendência para chover que dura vários dias seguidos, também a natureza da guerra não consiste na luta real, mas na conhecida disposição para tal, durante todo o tempo em que ao há garantia de não haver beligerância. Todo o tempo restante é de paz. ${ }^{138}$

No estado de natureza, em que os homens viviam em situação de plena igualdade (natural condição humana) e em plena liberdade (ausência total de impedimento), pode-se dizer que existia uma racionalidade, ainda que incompleta, devido a ausência de circunstancias especificas, como a linguagem, so existente na sociedade civil. Essa racionaliade explica a existencia da própria guerra.

Segundo a explicação de Maria Isabel Limongi, todo comportamento é explicado por uma paixão que por sua vez é determinada por uma circunstância. Por que os homens agem no sentido da guerra? existem varias razoes. $\mathrm{O}$ ataque em geral é uma antecipação. O homem, olhando para si mesmo, calcula que o outro irá agir como ele, ou seja, pretende atacar devido a situação miserável em que se encontra a humanidade: há medo generalizado. As mesmas circunstancias que levam o homem a ter esperança de obter um bem que o outro dispõe, uma

\footnotetext{
${ }^{137}$ A situação de guerra não precisa ser atual, pode ser somente potencial.

${ }^{138}$ Hobbes, Thomas. Leviatã p. 108-109.
} 
vez que a igualdade não fundamenta o acesso desigual a bens, há o temor que o outro tente obter os bens. A igualdade leva à competição, à desconfiança, ao medo e ao ataque, na forma de antecipação.

O que Hobbes quer mostrar é que qualquer um na mesma situação estaria impelido a atacar. E esse comportamento não advém da natureza humana, marcada pelo egoísmo. A determinação do comportamento é a circunstancia. Sendo a circunstância a plena igualdade e a ausência de poder comum, o ataque antecipado é a coisa mais racional a se fazer ${ }^{139}$.

Não existe, ao meu ver, uma dicotomia única estado de natureza e sociedade, como se um fosse a negação do outro. A oposição existe entre estado de natureza e sociedade política, aquela onde os homens podem se relacionar racionalmente (aquela em que existe autoridade legitima). Porem há certos tipos de sociedade em que vige o estado de natureza, concomitantemte. Na verdade, há sociedades que não merecem esse o nome, constituindo-se como verdadeiros estados de natureza. $\mathrm{O}$ estado de natureza é antes um significado que se atribui a determinada gama de relações entre os homens. Assim, reiterando, a sociedade cortesã abrigava a discórdia e a impossibilidade de relações racionais que impedissem a tendência à guerra. A sociedade cortesã abriga a instabilidade em seu seio, não sendo, portanto, uma sociedade política propriamente dita, mas um estado de natureza. O estado de natureza é uma abstração, um modelo ideal, e não uma situação histórica e nem uma situação de ausência de relações entre os homens a ponto de não haver linguagem. Da mesma forma que há espaço para a juridicidade (relações baseadas no direito) também há espaço para a linguagem, ainda que ambas sejam incompletas, inacabadas ou deficitárias, o que prejudicaria o pleno relacionamento entre os homens, o que impediria a paz.

Assim, nessa versão tradicioanl, qualquer sociedade, seja ela despótica ou não ${ }^{140}$, é melhor que o estado de natureza. Esta aí o prenuncio da racionalidade ${ }^{141}$, a noção de que o homem busca única e exclusivamente os seus interesses.

A sociedade é marcada pela presença do poder soberano ${ }^{142}$. Mais do que isso, a existência da soberania implica em sua posse $e^{143}$ por um individuo ou grupo, os quais teriam o

\footnotetext{
${ }^{139}$ Esse modelo tem grande alcance. As pessoas em geral manifestam-se diante de crimes bárbaros e atos de crueldade afirmando o absurdo daquela situação. Por exemplo, no caso de ataques terroristas, geralmente atribuise ao ato um gesto de loucura. Para Hobbes, todo comportamento tem por causa uma paixão, a qual por sua vez é explicada por uma circunstancia que a determina. Todo ato tem uma razão. Nesse sentido, o ato terrorista foi causado por alguma razao que cabe ao homem encontrar; não foi decorrência da irracionalidade, da loucura.

${ }^{140}$ Aqui há mais uma simplificação do Hobbismo. Como afirmar que a defesa de qualquer sociedade é melhor que o estado de natureza dado o apelo que a estabilidade e a segurança tinham em Hobbes, algo enfatizado mesmo pelo hobbismo?

${ }^{141}$ A palavra racionalidade em si não quer dizer nada. O que é racionalidade? Deve-se no discurso, sob pena de perda de seu potencial explicativo e comunicativo, dizer o que se entende por racionalidade, definir o termo e dar-lhe o sentido retirado da obra do pensador.
} 
direito (dever) de comandar os membros da sociedade, os quais deveriam entender, como expressão da racionalidade, que eles deveriam obedecer a tais ditames independentemente de seu conteúdo ${ }^{144}$. A doutrina arremata que além do dever de obediência a qualquer comando emanado do soberano os súditos devem toma-los como justos.

Num tempo de divergência aguda, Hobbes, num primeiro momento, percebeu a impossibilidade de princípios em si, de valores que possam ser tomados como intrinsecamente bons, ou de qualquer padrão moral critico que pudesse avaliar normas, regras e comandos. Perfilharia, Hobbes, então, entre as fileiras dos não-cognitivistas, aliando-se à Kelsen e Weber, exemplos notórios do ceticismo ${ }^{145}$ diante dos valores ${ }^{146}$ ?

Afirmar que Hobbes reza a cartilha de Weber não parece adequado nem mesmo às formulações do hobbismo. Enquanto Weber afirma que não existe padrão de justiça e explica tal assertiva à luz de considerações sobre a natureza das sociedades contemporâneas, marcadas pelo chamado desacordo moral ${ }^{147}$, Hobbes simplesmente afirma que o comando do soberano é justo, sendo assim existe a justiça e ela é identifica-se com a vontade do soberano.

O dever de obediência é decorrente do contrato social, do pacto de submissão que conferiu poderes absolutos ao soberano. Assim, o dever de obediência era constituído por duas razoes, ambas prudenciais. A primeira é a que deu origem a sociedade (qualquer sociedade é melhor que o estado de natureza), a segunda, afirma que ainda que o súdito não entenda a primeira razão, ele entenderá que o comando deve ser obedecido sob pena da sanção. Tal enquadramento faz de Hobbes um teórico do modelo imperativista do direito.

As interpretações usuais da obra de Thomas Hobbes, que enfatizam o seu autoritarismo $^{148}$, expressam uma versão banalizada calcada no pessimismo antropológico. Hobbes veria o ser humano como naturalmente mau, egoísta, agressivo, o qual não nutre nenhum prazer na comunhão com outros indivíduos. Dessa visão de homem surge uma teoria da sociedade, tida como reunião de indivíduos (sociedade atomística) cujo cimento social não

\footnotetext{
${ }^{142} ¥$ caracterizar a diferença entre comunidade e sociedade no pensamento de Tonnies £dicionario de pensamneto social

${ }^{143}$ Tanto contrato como posse são marcas que parecem endossar a famosa tese de C. B. Macpherson, A teoria política do individualismo possessivo. Como se tentará defender, trata-se de uma rota exagerada a simples identificação do pensamento hobbesiano como uma etapa do pensamento burguês em ascensão.

${ }^{144}$ Trata-se da frase mais atribuída aos positivistas e que frequentemente mais acarreta mal-entendido. Dizer que uma norma é valida independentemente do conteúdo soa uma defesa da tirania.¥citar Kelsen

${ }^{145}$ A relação entre o ceticismo do século XVII e concepções de ciências humanas do iniciio do século XX é um exagero, utilizado aqui para enfatizar as idiossincrasias do hobbismo.

${ }_{146}$ Carlos Santiago Nino, Introduçao à analise do direito,

${ }^{147}$ Luiz Fernando Barzotto

${ }^{148}$ Explicar a diferença entre autoritarismo e totalitarismo
} 
é produzido a partir de qualquer tendência natural à sociabilidade, pelo contrario, dado o descompromisso do ser humano com os problemas e aflições alheias, a sociedade somente poderia ser mantida pela coerção. O Estado, identificado com o poder soberano, aquele que não reconhece num mesmo território outro superior, seria instancia necessária e eterna, e sua lei, expressão dessas qualidades. O poder interventor e punitivo do Estado é o que permitiria a sociedade, salvando o homem de uma vida sem sentido, já que entregue as suas paixões. Os homens obedeceria às leis não somente porque se comprometeram num pacto de submissão original, mas pelo temor do castigo imposto pelas leis necessárias. Os conflitos, nascidos de características naturais dos seres humanos, seriam resolvidos somente pela intervenção do poder soberano, já que isso seria impossível contanto com a moralidade ou racionalidade das partes envolvidas $^{149}$.

Hobbes teria produzido, então, um arquétipo do autoritarismo, enquanto doutrina política adversária dos princípios liberais, sociais, democráticos. Numa sociedade que pleiteia a efetivação dos direitos humanos, não somente no plano internacional, mas no nacional ${ }^{150}$, a proposta hobbesiana para os problemas político-sociais parece golpear fortemente qualquer senso de moralidade política, exatamente por que Hobbes veria na democracia uma forma de governo não recomendável por abrir espaço à divergência e à instabilidade.

Então, o núcleo do pensamento político e moral hobbesiano seria derivado de uma noção fundamental, uma concepção da natureza humana, embasada na realidade, pois o homem é o lobo do homem (homo lupus hominis). Sendo os homens maus por natureza eles não tenderiam naturalmente a se associar a não ser por uma manifestação de vontade voltada a garantir algum interesse.

A doutrina política de Hobbes traria, portanto, uma das imagens mais significativas de uma certa concepção do direito: o homem mau. O grande jurista norte-americano Oliver Wendell Holmes utilizou a noção de homem mau para endossar sua teoria realista do direito:

Se vocês querem conhecer o direito e mais nada,observem o problema com os olhos do homem mau, a quem só importam as consequências materiais, que graças a esse conhecimento pode prever; não com os do homem bom, que acha razoes para a sua conduta, dentro ou fora do direito, nos mandamentos de sua consciência. Tomem, por exemplo, a pergunta fundamental 'o que é direito?' Descobrirão que certos autores dizem a

\footnotetext{
149 Esse trecho mostra claramente relações entre a teoria hobbesiana e os princípios da arbitragem, que geralmente compõe a primeira parte dos livros de dogmatica de direito civil.

${ }^{150}$ A Constituiçao da Republica Federativa do Brasil frequentemente é citada como exemplo do esforço da efetivação dos direitos humanos, estruturando os Estados e mobilizando suas forças político-institucionais a partir de certos objetivos, que explicitam um ideário comum das nações contemporâneas. ¥ colocar aqui José Afonso da silva e suas explicações dos objetivos da República
} 
vocês que é algo diferente do que os tribunais de Massachusetts ou da inglaterra decidem, que é um sistema de razão, que é dedução a partir de principios de ética ou axiomas universalmente aceitos, ou coisa parecida, que pode ou não coincidir com as sentençãs judiciais. Porem, se aceitarmos o ponto de vista de nosso amigo, o homem mau, veremos que para ele pouco importam os axiomas ou deduções, mas em compensação tem interesse em saber o que de fato resolverão provavelmente os tribunais de Massachussets ou da Inglaterra. Eu penso de maneira bem parecida. Entendo por direito as previsões sobre o que os tribunais farão concretamente, nem mais nem menos. "151

O homem mau se encaixaria perfeitamente na versão difundida de natureza humana atribuída à Hobbes. O homem mau é aquele que se move pela lógica dos interesses. Em prol da efetivação dos seus desejos o homem não encontraria barreiras, não teria escrúpulos. Não seria racional esperar que ele fizesse o contrário, ainda mais sabendo-se de antemão que a sociedade, dotada de recursos escassos, seria o reino da competição, nada anormal, portanto, entender o comportamento do homem que agiria racionalmente em favor daquilo que ele acha que é seu, que lhe garanta a sobrevivência.

É bom que se frise que a citação acima advém de um jurista extremamente preocupado em elaborar, ou até mesmo criar, uma perspectiva rigorosa e objetiva sobre o fenômeno jurídico, nobre o suficiente para se filiar ao esquema geral das ciências. Para tanto, não somente conceitos universais e eternos deveriam ser abandonados, conceitos esses que formariam uma concepção metafísica do direito, como também a própria noção de norma jurídica, o que impulsionaria a tarefa de descobrir a natureza do direito a dirigir-se à realidade concreta, a práticas sociais arraigadas, como aquelas associadas com os tribunais, onde os conflitos sociais são na prática decididos ${ }^{152}$. Alem disso, Holmes enfatiza o homem mau mas não diz que o homem bom (aquele preocupado em cumprir o seu dever, sendo o direito uma esfera moral acima de tudo) não existe, ao contrario de Hobbes, para quem a natureza humana seria irremediavelmente egoísta.

Desse modo, Hobbes e sua visão de natureza humana sintetizam o pior dos mundos, uma descrição unilateral, precária e metafísica da natureza humana (sem qualquer respaldo cientifico, estando alheio a qualquer comprovação intersubjetiva).

A imagem tradicional da teoria política de Hobbes se projeta em sua concepção de autoridade. M M. Goldsmith assevera que Hobbes se enquadra entre os positivistas juridicos. Assim, ao lado de Hobbes, encontrariam-se Austin, Bentham e Bergbohm. O famoso puzzle

\footnotetext{
${ }^{151}$ Oliver Wendel Holme, A senda do direito, apud Carlos Santiago Nino, Introduçao à analise do direito, p. 52 53.

${ }^{152}$ A concepção realista do direito é muito mais sofisticada que essa síntese pretende mostrar, formulada aqui apenas como chave argumentativa e ilustrativa dessa importante corrente da filosofia do direito.
} 
da filosofia do direito, que se explicita em forma de pergunta, seria respondido afirmativamente por esses teóricos. Assim, mesmo um tirano cria normas jurídicas validas, uma vez que nem a moral, nem qualquer outra coisa limitaria a sua vontade.

Para utilizar uma categorização proposta por Norberto Bobbio, Hobbes seria um positivista ideológico, isto é, um autor cuja teoria do direito está direcionada para fins políticos, para legitimar certos valores. Hobbes se encaixaria numa das mais nefastas manifestações do pensamento jurídico, responsável em grande parte pela acepção pejorativa do termo. Reiterando o que já foi dito no capítulo anterior, o positivismo ideológico esta calcado na ideia de que todo e qualquer ordenamento jurídico positivo deve ser obedecido. Assim, onde quer que se encontre o direito há uma obrigação moral de obedecer a lei, não importando se essa lei apareça injusta ou não. No caso de Hobbes, há ainda uma tinta de cinismo, uma vez que por definição a lei é justa, bastando que ela seja emanada do poder de fato. A obrigação de obedecer a lei se apoia nos valores da certeza, ordem e segurança, símbolos tradicionais de ditaduras e outras manifestações autoritárias, que encontrariam em Hobbes grande embasamento teórico. Além de Hobbes, o jurista alemão K. M. Bergbohm, cuja teoria encontrou forte receptividade no século XIX, é típico representante do positivismo ideológico, exatamente por isso seria um "hobbesiano"153.

Em resumo, para o hobbismo, soberano é aquele que não encontra em dado território qualquer limitação jurídica, inclusive o direito natural. Soberano é aquele que governa sem se reportar a qualquer outra autoridade, inclusive a eclesiástica, nem a moral, nem aos costumes $^{154155}$.

Observa-se então a importância do conceito de Soberania no contexto geral do pensamento hobbesiano, não somente como elo identificador do hobbismo, centrado na convergência entre autoritarismo e imperativismo, como centro organizador de uma nova concepção de política emergente.

Contrapor-se ao que chamei de versão banalizada não é tarefa fácil. Não só pela sua presença (ou quase onipresença) mas também porque ela é facilmente defensável pela mobilizaçao dos textos do próprio Hobbes. Há frases famosas e comprometedoras, que lidas ou invocadas solitariamente parecem fundamentar as acusações que a ele são dirigidas desde o século XVII. Mesmo autores do mais alto gabarito que leram todo o conjunto de obras

\footnotetext{
${ }^{153}$ Dimitri Dimoulis, Introduçao ao Estudo do Direito

${ }^{154}$ Segundo Norberto Bobbio essa visão é equivocada (é exatamente o que se pretende afirmar). O único filosofo que afirma ser o soberano ausente de quaisquer limitações é Maquiavel. ¥elaborar

${ }^{155}$ Talvez seja exagero reputar ao hobbismo a noção de que o soberano não encontra limitações de qualquer natureza, mas sim em Deus somente. Porem, há uma profunda incoerência afirmar que o soberano não encontra limitações jurídicas mas somente é limitado por Deus.
} 
hobbesianas a partir de metodologia rigorosa defendem que Hobbes é um defensor incondicional do poder absoluto, único capaz de permitir a existência da comunidade política. Há outros autores que não somente leram todo arco da produção intelectual de Hobbes como também recorreram ao mapeamento de toda a produção intelectual do período em que ele viveu, e ainda assim, apesar deste esforço descomunal e do enriquecimento do debate, inclusive com a criação de novas frentes de pesquisa, no tocante ao problema da obrigação política, endossaram a versão tradicional ${ }^{156}$.

Não é possível, no entanto, deixar de registrar que ao lado desta versão tradicional há uma profusão de interpretações, tão numerosas quanto verossímeis, o que faz avançar o entendimento das características dos escritos de Hobbes. Por mais que o interprete queria legitimar a sua interpretação, muitas vezes tem que reconhecer a plausibilidade de outras que defendem teses frontalmente opostas. Tom Sorell, grande schollar hobbesiano, ao organizar o debate num texto introdutório afirma que duas leituras são possíveis e válidas, aquela que cola os trabalhos de Hobbes aos acontecimentos da época, e outra enxergada em nível de abstração o mais amplo possível ${ }^{157}$, o que salienta os múltiplos sentidos ínsitos ao pensamento do intelectual de Malmesbury.

A leitura da obra hobbesiana explicita tão logo uma tensão: como conciliar o que nos diz a tradição com a postura de cautela adotada assumida na dedicatória de Leviatã ${ }^{158}$ ? Hobbes, escolhendo o "caminho do meio", escreve ${ }^{159}$ temeroso pelo destino de sua obra, que "num caminho cercado por aqueles que, se batem de um lado por excessiva liberdade, e, de outro, por excessiva autoridade ${ }^{160}$, é difícil passar sem ferimentos por entre as lanças de cada $u m^{161}$.

\footnotetext{
${ }^{156}$ Refiro-me principalmente ao contextualismo linguístico e à Quentin Skinner, sua figura mais importante, que será mencionado mais adiante.

${ }^{157}$ SORELL, Tom. Hobbes, p. 728.

${ }^{158} \mathrm{Na}$ dedicatória ao livro de Thamy Pogrebin Renato Janine Ribeiro enfatiza que toda a leitura da autora sobre a obra de Hobbes centra-se no entendimento de determinado trecho, que se choca frontalmente com a imagem de um hobbes secular. Do mesmo modo, este trabalho,sem seguir o mesmo intinerario da autora, nem se balizar por seus principais argumentos, tomou o texto citado como ponto importante para o desenvolvimento da linha interpretativa.

${ }^{159}$ Essa citação já foi transcrita na introduçao deste trabalho. Dada a sua grande importância, por ilustrar, nas palavras do próprio autor, sua rejeição ao excesso de autoritarismo, justamente o sentido que mais atribuem a sua obra. Além disso, reflete justamente a tensão que conecta os modernos aos contemporâneos, e que identifica os excessos que as escolas contemporâneas mutuamente se atribuem umas as outras.

${ }^{160} \mathrm{Na}$ estranha passagem, quando Hobbes teme pelas lanças dos que prezam pela excessiva autoridade, de quem ele está falando? A mais pálida explicação pede a ajuda do cenário intelectual da época o que foi feito por
} 
Como conciliar a ênfase conferida a um monstro inexpugnável, capaz, com sua força e sua vontade, de esmagar os homens que o criaram com a afirmação do próprio Hobbes, segundo a qual o Leviatã, artifício do homem, o Homem artificial, fora criado para proteger e defender os interesses dos seres humanos ${ }^{162}$. Onde está e em que consiste a racionalidade da criação do Estado e a justificativa para a saída do estado de natureza?

Em outro momento de sua introdução, logo após expressar o velho ditado "leia-te a ti mesmo", Hobbes assevera que "esse ditado não pretendia ter o sentido, atualmente habitual, de aprovar a bárbara conduta dos detentores do poder para com os seus inferiores, ou de levar homens de baixa estirpe a um comportamento insolente com os seus superiores". 163 Assim, mais uma vez Hobbes coloca-se no "caminho do meio", negando se filiar às hostes autoritárias $^{164}$.

Qual é a opção conciliatória que Hobbes realizou? Qual a natureza desse poder comum a que todos obedecem, capaz de vencer a miséria do estado de natureza? O que justifica a renúncia dos direitos naturais e a submissão a esse poder comum? Qual a natureza da autoridade proposta por Hobbes?

Richard Tuck. Segundo o famoso historiador, tanto a ideia de direitos naturais como a noção de estado de natureza se remetem a obra de Hugo Grotius, o qual tem notáveis paralelos com a vida de Hobbes. Assim como o filosofo inglês, Grocio foi um humanista de notável cultura e com vida atribulada, pautada por grandes viagens o que lhe propiciou conhecer os grandes homens. Grocio, também chamado de teórico do absolutismo, tem a sua obra As leis da guerra e da paz, de 1625, rotulada como defensora do absolutismo. De fato, ela não é liberal. Na chave proposta por tuck, que relaciona todo o desenvolvimento filosófico do século XVII com o ceticismo de Montaigne e Lipsius, a formulação dos direitos naturais por Grocio, como uma resposta aos desafios céticos, sem cair na vasta tabua de direitos aristotélicos, transformava o principio de autopreservação em uma espécie de moralidade. Porém, o que poderia servir, como de fato posteriormente ocorreu, como uma esfera intransponível de moralidade a pautar e limitar o poder, passou a ser a fundamentação do absolutismo e da escravidão. Esse é mais um exemplo de como identificar a cartilha de direitos naturais e individualismo ao liberalismo é uma simplificação. Cf. Richard Tuck, Hobbes, $p$. 38. Nessse sentido havia teóricos do autoritarismo com os quais Hobbes não se identificava. Exatamente nesse sentido que Grocio pode também estar sendo vitima de simplificação. Segundo o próprio Tuck, Grocio afirma que direitos naturais podem fundamentar a necessidade do poder coercitivo do Estado, o que se encaixava nas praticas políticas efetivas da época. Ao dizer isso, Tuck não somente abre uma ponte para entender a razoabilidade das ideias de Grocio como a de Hobbes por extensão, baseada em aspectos fáticos, históricos e não propriamente teóricos. Não se deve culpar Tuck por não trazer essa fundamentação uma vez que ele não se propôs a isso. No contexto de sua obra, o que se ressalta são os aspectos do debate da época que influenciaram decisivamente a obra de Hobbes, deixando para investigações analíticas a tarefa de reconstruir os argumentos propriamente ditos. Achei poucos trabalhos realizados no Brasil que tratem do tema, destacando Paulo Emílio Vauthier Borges de Macedo, Hugo Grócio e o Direito, Lumen Juris editora e Cícero de Araújo, Teoria humana das virtudes e o contexto jusnaturalista, Tese de doutorado, USP, além do breve estudo introdutório de

${ }^{161}$ Leviatã, p. 5. Esse trecho foi o primeiro que me causou grande impressão. Hobbes afirma claramente que o seu objetivo é estabelecer uma teoria política que não se identifica com uma adesão a uma forma de regime cujo soberano está sempre certo e por extensão seus comandos independentemente, nem com aqueles que chamam de soberano quem é capaz de editar a norma certa e por isso deve ser obedecida.

162 "Porque pela arte é criado aquele grande Leviatã a que se chama República, ou Estado (em latim Civitas), que não é senão um homem artificial, embora de maior estatura e força do que o homem natural, para cuja proteção e defesa foi projetado. " Leviatã, p, 11.

${ }_{164}^{163}$ Leviata, p. 12. 
Essa série de perguntas dão à tônica dessa dissertação ao mesmo tempo que explicita a atualidade do pensamento de Thomas Hobbes.

Hobbes quer explicitar a racionalidade que está na escolha dos homens em ingressar numa sociedade em que o poder, ainda que representativo, situa-se num quadro institucional ilimitado juridicamente.

Tentou-se, por via de exposição de alguns conceitos e explicitação de versões correntes da obra de hobbes, fornecer um quadro panorâmico onde se situa o problema fundamental dessa pesquisa, o qual posiciona Hobbes diretamente no debate contemporâneo.

Quando Hobbes pontua que seu livro pode ferir a sensibilidade daqueles que se debatem por grande liberdade, significa que é necessário enfrentar uma questão fundamental. O homem é movido a todo instante a fazer escolhas, o que implica agir de acordo com razoes e ponderar sobre valores.

As questões religiosas impunham a todos graves dilemas que exigiam a tomada de posição. A turbulência era tão grande, assim como o dissenso tão impactante, que a atitude cética ganhava grande ímpeto. Não somente pela constatação da pluralidade de valores e o desafio imposto para a justificação de princípios morais últimos, mas porque a adoção de valores impõe a assunção de compromissos em sua direção. Segundo os céticos, tal postura poderia colocar as pessoas em risco ${ }^{165}$.

Hobbes encara de frente esse desafio. Como vencer a discórdia que parece inerente ao ser humano, uma vez que o homem, em nome de suas crenças, engaja-se em consonância com elas, sem cair na postura cética? Como criar bases sustentáveis para a existência e estabilidade da sociedade tendo em vista a plena liberdade em ação em função de valores que parece estar na origem dos conflitos?

Hobbes se propõe a justificar racionalmente a criação do Estado que somente pode existir se a liberdade de agir segundo as razoes individuais for substituída pela adesão a regras emanadas pela autoridade. O que explica a escolha pela heteronomia, isto é, a obediência às regras ainda que não se concorde com o seu conteúdo?

Há um enorme dissenso sobre a questão. Apenas para ilustrar essa complexidade, apresento agora três versões do pensamento hobbesiano.

A primeira é a visão absolutista. Em linhas gerais, é idêntica ao hobbismo. Nesta dissertação, a conotação dada ao hobbismo envolve os textos que pretendem menos entender e interpretar Hobbes que acusá-lo como o símbolo da irracionalidade. O grande equívoco 
dessa linha, conforme leitura dos comentadores destacados, é com relação ao entendimento de conceitos importantes da teoria hobbesiana, tal como a definição de natureza humana e o endosso do ser humano como alguem que somente segue a razao prudencial, agindo em prol de interesses, não havendo possbilidade para a cooperação. Somado a isso, esta a definição de direito como ordens garantidas pela coerção, na linha do modelo imperativista do direito.

A outra versão é a jusnaturalista. Em linhas gerais ela prevê uma apreciação do conteúdo da diretriz da autoridade, bem como a recondução da validade dos atos de poder a algum bem moral compatível com o paradigma jusnaturalista.

A terceira versão é a que chamarei de jurídica ou da legalidade. Essa versão é a que fornece as razoes de obediência a partir do elemento juridico. Em outras palavras, uma vez reconhecido de que se trata de uma diretriz compatível com o direito (valida ou obrigatória) tem-se configurado o dever de obediência. $\mathrm{O}$ avanço dessa tese permite afirmar que a teoria jurídica hobbesiana apresenta uma versão de Estado de Direito.

Entre aqueles que defendem que Hobbes fez a opção total pela heteronomia, a partir da ideia de que toda e qualquer sociedade é melhor que o estado de natureza figura-se Quentin Skinner, notável intelectual que se tornou o principal representante do chamado contextualismo linguístico.

Skinner sustenta que as obras devem ser lidas à luz do debate da época, ou seja, por influencia do contexto imediato, sob pena de anacronismo. Este método possibilitaria trazer à baila as questões que motivaram diretamente os pensadores. O entendimento da obra de um autor se faz de fora para dentro, isto é, com os recursos provenientes dos discursos políticos da época, que iluminariam a leitura. O contexto iluminaria o texto. Skinner, destacado estudioso da obra de Thomas Hobbes, defende que havia à época um publico que entendia a natureza humana como essencialmente egoísta, com natural antipatia dos seres humanos. $\mathrm{Ou}$ seja, a visão da natureza maligna do homem, aquilo que foi chamado de pessimismo antropológico era plenamente condizente com o debate da época, o que endossa a visão do hobbismo ${ }^{166}$. Como o homem somente agiria em prol do seu próprio interesse, somente a existencia de um soberano a quem se deve obediência incondicional possibiltaria a existencia da sociedade. Para Skinner, Hobbes era um entusiasta da soberania de fato, isto é, todo e

\footnotetext{
${ }^{166}$ Skinner utiliza o termo hobbista para essa visão,mas o conceito é o mesmo.
} 
qualquer soberano (detentor do poder Maximo) era merecedor de obediência ${ }^{167}$ Como se verá, Maria Isabel Limongi esclarece que o argumento hobbesiano é mais sofisticado que isso ${ }^{168}$.

Nesse sentido, a resposta para a obediência à lei é a fuga do estado de natureza, ou seja, uma vez que a renuncia da liberdade de escolha implica na saída de uma situação de miséria, qualquer ordem do soberano é melhor que a situação anterior. $\mathrm{O}$ estado de natureza consiste na plena liberdade dos indivíduos, onde não há impedimentos. Nesse sentido, a possibilidade plena de contestação, de opçao valorativa, tornava o ambiente propricio ao embate, pois não haveria meios para a resolução de conflitos.

Um texto de Hobbes ilustra de maneira significativa a relação entre estado de natureza, plena liberdade e ausência de estruturas comuns para a resolução de conflitos:

"E como tal na Aritmética, os homens inexperientes, e mesmo os professores, podem muitas vezes e errar falso, também em qualquer outro objeto o raciocínio os homens mais capazes, mais atentos e mais experientes podem se enganar e inferir falsas conclusões. Não porque a razao em si própria não seja sempre a razao reta, assim como a aritmética é uma arte infalível e certa. Mas a razao de nenhum homem, nem a razao de que número for de homens, constitui a certeza, tal como nenhum computo é bem-feito porque um grande número de homens o aprovou unanimemente. E, portanto, tal como ocorre numa controvérsia a propósito de um calculo - quando as partes precisam, de comum acordo, recorrer à reta razão, à razão de algum árbitro ou juiz a cujo juiz se submeterão, ou do contrario sua controvérsia chegará as vias de fat, ou permanecerá indecisa por falta de uma reta razao constituída por natureza -, o mesmo ocorre em todos os debates sejam em que espécie forem. Quando os homens que se julgam mais sábios do que todos os outros clamam e exigem a razão como juiz, apenas procuram que as coisas sejam determinadas, não pela razão de outros homens, mas pela sua própria, e isso é tão intolerável na sociedade dos homens como é no jogo, uma vez. escolhido o trunfo em todas as ocasiões aquela série de quem tem mais cartas na mão. Pois com isso nada mais fazem do que tomar por reta razão cada uma das paixões que sucedem dominá-los, e isto nas suas próprias controvérsias, revelando a sua falta de reta razão pelo fato de reclamarem dela. "169

Esse parágrafo se constitui uma invocação adequada para a tese absolutista. Ela parece sustentar a justificativa da autoridade ou da constituição da autoridade mostrando a racionalidade que está por trás da entrega aos ditames de um poder incondicionado.

\footnotetext{
${ }^{167}$ SKINNER, Quentin. "Hobbes and the Purely Artificial Person of State"

${ }^{168}$ Hobbes,p. 11.

${ }^{169}$ Leviata, p. 40. Trata-se de um dos parágrafos mais importantes do Leviatã, ao reunir elementos importantes da teoria política e juridica formadoras do nosso solo de legalidade.
} 
Hobbes mostra que numa sociedade sem instituições que se situem além das partes envolvidas no conflito não é possível por termo à discórdia. Não é 'possivel os homens entrarem em acordo, porque não existe o bom argumento, a Razão que se imporia pela certeza.

A única solução é a escolha de um terceiro capaz de ditar a solução, seja ela qual for. A disputa consistente no choque de razoes é solucionada pela Vontade de um terceiro LIVREMENTE escolhido pelas partes. A reta razão não pode ser invocada para a solução do conflito, porque ela é apenas a manifestação da paixão. Toda a racionalidade consistente no consentimento à submissão da decisão do terceiro se identifica com a argumentação contida nesta passagem

A crítica que poderá ser feita é a de que esta descrição da racionalidade da criação da arbitragem ainda é insatisfatória. O que garante, no estado de natureza, que um individuo que consentiu obedecer a resolução do arbitro irá de fato obedece-la após a sua ediçao? Se o individuo desprestigiado em sua pretensão não concordar, por não achar correto, com a decisão do terceiro, o que o fará acatar uma decisão que ele considera injusta? em outras palavras, ele pode ter se arrependido de ter feito um acordo para a escolha de um terceiro ao ver que a vontade deste terceiro choca-se com a sua razão.

Nesse momento, os partidários do absolutismo (hobbismo) avançam mais uma de suas teses: o esquema somente funcionara se o terceiro for um juiz, alguem com força o suficiente para fazer valer a sua determinaçao. Nesse sentido, é da essência do sistema da arbitragem a existencia da coerção e o fundamento para a sua utilização é o acordo feito previamente. Para o fim das controvérsias, a coerção é necessária e constitui-se como propriedade fundamental do direito.

É importante frisar que a não aceitação da decisão do arbitro afirma que na verdade o acordo feito previamente não tinha nenhum respeito pelas partes. Ou seja, a razão ou o fundamento do contrato não foi levada em conta no momento da escolha de não se acatar a decisão do terceiro. Para a parte, então, o fundamento da sua escolha de obedecer a decisão do terceiro foi a força, isto é, de ter sido respaldada por uma força inexpuganavel. A razao da obediência não consiste então no acordo prévio, mas na força.

Reiterando, para o súdito, do ponto de vista da parte desprestigiada pelo juiz, a razao de obediência é a coerção,não havendo portanto nenhuma adesão à autoridade do juiz. Do 
ponto de vista do juiz, ele pode sim fundamentar a sua decisão no acordo, afirmando, portanto, que ele tem direito de comandar.

A tese da coerção necessária encontra sustentação em uma das lições mais difundidas do pensamento hobbesiano. Segundo essa visão, hobbes afirmava a completa imoralidade do ser humano. O homem tem uma natureza maligna, voltada ao ataque. O homem não tem prazer nenhum na convivência, pelo contrario. Eles são naturalmente inimigos uns dos outros. O homem é o lobo do homem. O estado de natureza é o retrato da natureza maligna do homem.

Assim sendo, a naturza humana explicaria tambem a impossibilidade do homem cumprir o acordo, uma vez que se volta apenas as suas paixões egoístas.

O homem seria incapaz de conviver com outros seres humanos, a sociedade não existiria se o homem não fosse forçado a isso, pois nenhuma razao o impeliria a agir contra os seus interesses.

O que se quer frisar, antecipando o que se falará adiante, esse esquema é altamente contraditório no sentido de que há um "déficit de racionalidade". ${ }^{170}$ isso significa que um direito não corresponde a um dever, ou seja, a mesma circunstancia não permite que as partes envolvidas entendam que o consenso legitima juridicamente a decisao do terceiro. $\mathrm{O}$ acordo gera direitos para o terceiro detentor da força, mas as partes não se sentem obrigadas. $\mathrm{O}$ acordo não é capaz de gerar obrigações.

Se o estado de natureza é decorrente da natureza egoísta do ser humano, isso significa que a razão prudencial é colada na situação em que se desenvolveu a ordem. A razão é meramente prudencial e não se refere a nenhum contrato prévio. Se o homem é movido pelos interesses, a renuncia a liberdade de escolha se faz pela coerção de um ser todopoderoso.

Enfatiza-se que se o estado de natureza nasce da natureza humana a definição de direito passa pela coerção, pelo comando, pela fato de existir um poder inexpugnável. Tal esquema é incapaz de gerar obrigação e está em desacordo com a própria definição de direito fornecida por Hobbes ${ }^{171}$

\footnotetext{
${ }^{170}$ Cunhei essa expressão inspirada em outra utilizada por Joseph Raz: "piece-meal", que foi traduzida para o portugues como "abordagem fragmentária". Raz, Joseph. Moralidade da Liberdade, p.73. Em inglês, Raz.The Morality of freedom, p.74.

${ }^{171}$ Leviatã, p. 225.
} 
O próprio Skinner mitigou a sua posição em outro texto ${ }^{172}$. artigo intitulado The proper signification of Liberty. Isso reflete de maneira significativa a controvérsia em torno do pensamento hobbesiano.

Esse esquema é pobre o suficiente para se dizer que a ele falta a normatividade. Que diferença faria às partes se em vez de um terceiro a decisão fosse proveniente de se "tirar a sorte" jogando moeda? a decisão não foi feita a partir de nenhuma regra, o arbitro agiu livremente, sem regra que pautasse a sua deliberação. Não existe a lei previa e conhecida que possibilitasse regular a decisão do terceiro.

O que Hobbes parece estar dizendo é que o correto, o justo, a reta razão coincide com a vontade consistente na decisão tomada pelo terceiro escolhido.

É aqui que entra uma das questões mais delicadas da teoria hobbesiana que é a relação entre a lei natural e a lei civil. Segundo Hobbes "a lei da natureza e a lei civil contêmse uma à outra e tem igual alcance".

Norberto Bobbio traz importante e significativa leitura do pensamento hobbesiano. Se propondo a analisar a intrigante relação entre lei natural e lei civil,

Bobbio tenta responder porque um autor jusnaturalista é tambem identificado com o positivismo juridico. A isso ele chama de paradoxo hobbesiano ${ }^{173}$.

Bobbio, partindo da chamada justiça formalista, que alude à solução nominalista de Skinner, afirma que a justiça é agir de acordo com a lei, melhor dizendo, é cumprir obrigações, seja o cumprimento da lei, seja o cumprimento do contrato.

De forma geral, Bobbio afirma que a lei natural nada mais é do que um instrumento racional que faz o homem optar pelo sociedade, ou seja, faz o homem assumir a obrigação, mediante um pacto de submissão, para obedecer todo e qualquer lei emanada do soberano.

Nesse sentido, a resposta da escolha da heteronomia se faz pela determinação do sentido de lei natural.

Como observa Maria Isabel Limongi, as mesmas razoes que levam à guerra generalizada move o homem para o estabelecimento do contrato social que instaura a sociedade civil:

\footnotetext{
172 “The proper signification of Liberty”, in Skinner, Visions of Politics, 2006

173 Bobbio, Norberto.Thomas Hobbes, p. 102.
} 
"Do mesmo modo que é razoável supor, a partir de um calculo acerca das paixões humanas, que, na ausência de um poder comum a que todos obedeçam, em condição de igualdade de poder, os homens tenham motivos para disputar com os outros, desconfiar deles e procurar obter maior poder pessoal, é tambem razoável supor que os homms percebam as contradições dessa condição e dela queiram sair"

A consciência da situação de guerra, de miséria e medo leva o homem a procurar a paz. A escolha é racional em direção a renuncia do poder de fazer tudo, da liberdade de escolher o que se considera melhor em cada caso, em prol da garantia de proteção.

Porem, o desejo de paz afirma que qualquer sociedade é melhor que o estado de natureza? Bobbio afirma que a solução hobbesiana é radical, uma vez que a escolha é pela soberania absoluta, isto é, pela criação de "um Estado cujo poder seja o mais privado de vínculos e limites que se possa humanamente conceber",174

Essa opção é no mínimo intrigante, uma vez que o homem que vive no estado de natureza escolhe entregar-se à deliberação de um soberano que age sem limitações. Nesse sentido, o que impediria esse soberano, que não pode ser julgado, a agir de forma tiranica?

"Mas poderia aqui objetar-se que a condição do súdito é muito miserável, pois se encontra sujeito à lascívia e a outras paixoes irregulares daqueles ou daquele que detem nas suas mãos poder tão ilimitado(...)E isto sem levar em conta que o Estado do Homem nunca pode deixar de ter uma ou outra incomodidade, e que a maior que é possível cair sobre o povo em geral, em qualquer forma de governo,é de pouca monta quando comparada com as misérias e horríveis calamidades que acompanha a guerra civil, ou aquela condição dissoluta de homens sem senhor, sem sujeição às leis e a um poder coercitivo capaz de atar as suas mãos, impedindo a rapina e a vingança",175

Qualquer governo é melhor que estado de natureza, essa é a resposta sintética que Hobbes parece entregar. Qualquer ordem, com qualquer conteúdo, por mais que nos afete, por mais que nos ultraje, é melhor que a anarquia.

Outra pergunta surge: como é possível ao homem no estado de natureza perceber as vantagens da renuncia da autonomia? Reiterando, os homens que entenderam o horror do estado de natureza e o estado de miséria que o direito a fazer tudo para garantir os seus interesses e a sua preservação conduz perceberão que qualquer coisa, qualquer situação social

\footnotetext{
${ }^{174}$ Bobbio, p. 103.

${ }^{175}$ Hobbes, Leviata, p. 157.
} 
é melhor que o estado de natureza. Os homens entenderão e perceberão as vantagens do estado de natureza mediante a lei natural. A lei natural é o passaporte para o novo mundo, o bilhete racional que conduz o homem a outra situação de existencia, onde a vida é valida. A lei natural conduz o homem a um estagio superior da existencia, superando as barreiras impostas pela sua natureza maligna. A lei natural é a escada que supera o muro que separa a natural condição da humanidade e a sociedade.

Para alguns autores, a natureza dessa escada tem o papel de compelir o homem a sair da situação de miséria ${ }^{176}$. Norberto Bobbio é um dos entusiastas da tese da escada, a qual ajudou a elaborar: ${ }^{177}$ "a lei natural hobbesiana, ainda que esta afirmação possa parecer paradoxal, tem a única função de convencer os homens que só pode existir um único direito, o direito positivo.",178

É nesse momento que Bobbio oferece uma resposta. A lei natural tem o papel de fazer o homem enxergar a sua situação miserável. Então, a lei natural é que eliminaria a aparente irracionalidade dessa opção, tal como se alinha ao texto acima.

O esquema absolutista implode o paradima jusnaturalista dualista. A mesma lei natural que fornece a razao para a obediência completa à vontade do soberano. Segundo Bobbio, Hobbes afirma que a lei civil não poder ser contraria a lei natural. Mas isso não significa o endosso do paradigma jusnaturalista. É a sua anulação. A lei natural afirma que a lei civil é a única valida porque emanada do sooberano. A lei natural tambem diz que todas as outras leis naturais são invalidas.

A outra leitura pode ser denominada de jusnaturalista. Essa leitura é condizente tambem com a dedicatória, aquilo que parece optar por um caminho do meio, não se identificando com os entusiastas da plena liberdade, nem os que apregoam as virtudes do excesso de poder.

É possível ilustrar esse argumento a partir da teoria da autoridade. Uma decisão proveniente de uma autoridade (não de um terceiro) impoe obrigações. Isso significa que a "lei" recebe adesão intensa por parte dos destinatários a ponto de compor o seu balanço de razoes. O comando exclui as demais razoes. É bom frisar que a tese jusnaturalista implica em

\footnotetext{
${ }^{177}$ A tese da escada assume uma natureza obrigatória devido ao imperativo de sobrevivência. Para importantes lições sobre tal tese ver. LLOYD, S. A. “Hobbe's self-effacing Natural Law theory." n82, 2001, p. 258. A ideia de escada é que após ter subido o muro ela é abandonada.

${ }^{178}$ BOBBIO, Norberto.Thomas Hobbes, p.128.
} 
duas vertentes. A primeira afirma que não existe propriamente comando, uma vez que a autoridade é legitimada pela lei natural. Não no sentido em que fundamenta a razao prudencial. Porem, a lei natural tambem atua nas regras. As determinações do soberano são avaliadas pela lei natural, ocorrendo, portanto, uma avaliação de conteúdo. Todas as determinaços da autoridade que ferirem o principio a vida não são validas.

Esse afirma que a lei natural existe na socieade civil, é operativa e fundamenta o direito de resistência, por exemplo. A questão dessa interpretação (aqui faço uma interpretação) é que nele existe sim uma apreciação de conteúdo das diretrizes da autoridade. Se ela humilhar,ou aviltar o súdito não existe mais o dever de obediência, configurando a situação paradoxal de estado de natureza individual, isto é, o individuo volta ao estado de natureza porque não tem mais limitação e readquire o seu direito à tudo. Outra constatação desse modelo é que o poder do soberano é absoluto mas não ilimitado juridicamente, em outras palavras a lei natural cancela o dever de obediência ao soberano.

Qual a plausibilidade desse esquema? apenas como ilustração da possibilidade da existência de uma lei natural que funda o direito de resistência. Dizer que uma diretriz do soberano não é lei porque se choca com a lei natural, significa que superou-se a ideia de que o direito consiste em fontes sociais. Ou seja, para se determinar o que é o direito deve-se observar a autoridade, ou as fontes de direito criadas pelo próprio direito. se, pelo contrario, o direito existe dependendo do teste de conteúdo, ou seja, independentemente da fonte social a lei pode ser injusta pelo seu valor intrínseco e esse valor se torna um valor reconhecido pela lei natural. O homem é capaz racionalmente de conhecer essa lei natural. A lei natural como conteúdo em outras palavras afirma a conexão necessária entre direiot e moral.

Se o homem é capaz de identificar o certo, que é a lei natural, porque ele é incapaz de concordar quanto ao conteúdo das disposições de direito? se o homem é racional de identificar o conteúdo da razao que legitima o soberano (que na linha de Tuck e Skinner é o direito a autopreservaçao) porque o homem discorda entre si mesmo sabendo o que é certo? Segundo Maria Isabel limongi "Hobbes não fornece elementos para compreender como precisamente isso se dá em relação às leis da natureza".

O que ela explica é que a lei da natureza, sendo lei, obriga. Toda e qualquer obrigação cancela a liberdade de escolha, isto é, aponta uma direção. A questao fundamental é que a obrigação afirma que devemos agir em uma direção ainda que entendamos que ela não é 
correta. Mas se estamos falando em lei natural, tal esquema não tem sentido, porque a lei natural é descoberta pela razao, isto é, ela é correta.

A pergunta que surge é a seguinte: por que o homem, no estado de natureza, conhece o que é certo mas não o cumpre? SE pela tese jusnaturalista o homem é capaz de conhecer o que é certo, isto é, conhecer a lei natural e esse conhecimento possbilita a apreciação de conteúdo da diretriz de autoridade na sociedade civil a ponto de fundamentar o direito de resistência, por que no estado de natureza este mesmo homem não pode entrar em acordo e se submeter ao que é certo e não à vontade do arbitro?

A resposta que pode ser esboçada é que no estado de natureza a lei natural não se realiza. Isto é, o estado de natureza não permite o pleno desenvolvimento da razão de modo que os homens possam coordenar as suas ações por ela.

Diante disso, se o hobbismo afirma que o homem se submete a autoridade, renuncia a sua autonomia, porque somente a coerção pode conter a imoralidade humana, se o esquema absolutista afirma que o homem renuncia a autonomia porque qualquer coisa é melhor que o estado de natureza e o entendimento dessa assertiva é dada pela lei natural, que se configura como uma escada que é abandonada após passar-se pelo muro, a tese jusnaturalista afirma que a submissão à autoridade é feita porque somente na socieade civil a lei natural se realiza, porque a racionalidade se torna perfeita. Ou seja, somente o estabelecimento da autoridade permite a moralidade. Nesse momento, a lei natural que no estado de natureza não era propriamente uma lei, porque não vinculava, em razao das circunstancias que tornavam irracional agir em prol das razoes geradas pela lei natural, na sociedade civil ela se torna uma lei completa.O direito então é dualista e por isso Hobbes afirma que a lei civil e a lei natural são iguais.

O que esse esquema jusnaturalista não responde é porque o soberano agiria incorretamente? Se a sociedade civil é o espaço em plena operatividade da lei natural de modo que é possível nesse momento conceber o que é justo, porque o soberano que foi instituído para a plena efetivação da lei natural e da moralidade agiria contra ela. Se a moral torna-se objetiva, completa, porque a vontade do soberano se chocaria com a Razão?

O esquema jusnaturalista parece não dar conta do capitulo V do leviatã.

Em termos resumidos, a terceira leitura enfatiza a legalidade. Essa gera uma atmosfera juridico-politica que viabiliza o relacionamento racional a sociedade propriamente dita. Segundo ela a opção pela heteronomia é a paz. É possível avançar a proposta e dizer que 
é a proteção. A ideia de proteção é importante porque remete ao fortalecimento da adesão a regra. Há uma dimensão moral na estrutura do estado.

Maria Isabel Limongi afirma que Hobbes simboliza, como seu pensamento, a própria noção de política moderna. Ele elimina toda e qualquer nota naturalística do pensamento político, afirmando que a convivência é algo em aberto, a ser realizada pelos homens. Entre os elementos decisivos para essa nova concepção de política estava o como artificio humano, criado por uma finalidade, e a emergência do individuo. Há uma conotação pejorativa de individuo porque o estado de natureza é o espaço em que os seres não se relacionam, vivem isolados, exatamente porque são inimigos uns dos outros.

Como já foi mencionado essa visão é equivocada. O homem é um ser múltiplo, formado por varias paixões. A questao do individuo é que todos são iguais. Não havendo diferenças entre eles que justificassem a posse de poder, rompe-se a ideia de virtude e passase a pensar no lado da técnica. Qual é a estrutura estatal que possibilitasse o cumprmento de algumas funções. Essa estrutura, pensada em prol de finalidades humanas, serão ocupadas por qualquer individuo, uma vez que todos são iguais. É a situação já mencionada de Skinner como a concepão de Estado criado para o cumprimento de finalidades e a visão do soberano como alguem que não mais conserva o seu estado, a partir da habilidade, sorte e competência. A riqueza do Estado está na sua estrutura, no seu caráter institucional.

Se o grande marca da política é a razao estratégica, voltada para o cumprimento de funções, o maior objetivo da época era estabelecer as condições básicas de sobrevivência, seja determinar as regras comuns e tambem a estrutura do poder político. O elemento fundamental para a estabilidade era o contrato.

O contrato social é o marco fundador da sociedade. ele ira estabelecer o fundamento da obediência e do dever do soberano para comandar. Para Limongi, o elemento juridico, que é o contrato, capaz de dar estabilidade ao corpo social, é o contrato. Ele é caracterizado por ser um pacto de submissão, em que há renuncia da vontade individual em prol da vontade social, a vontade do soberano.

O que o contrato instaura é a obrigação de obedecer o soberano. Essa obrigação é juridica e corresponde ao estabelicido no contrato. $\mathrm{O}$ sistema obrigacional que constitui a sociedade é que vai permitir a racionalidade da obediência. 
Diante de um ditame da autoridade que pareça injusto, a obediência se faz por que é advinda do contrato. Dentro do balanço de razoes individuais, a ordem do soberano exclui as demais, principalmente porque há o respeito e principalmente identificação de que é o direito.

Para Hobbes, o direito não inclui a coerção entre os seus elementos constituitvos. A opçao pela heteronomia é concretizada por um contrato que irá fundar a sociedade em torno de um poder comum que todos respeitam, mas não o temem. Respeitam poque ele tem a função de governar, de se dirigir as seus interesses, e respeitam porque foi uma escolha racional, cuja vontade é explicitadano contrato.

Se dois homens resolvem fazer um contrato, o que cria a obrigaçao? a existencia desse contraoo entre as partes não gera o dever de obedecer. É necessária a exitencia do Estado, que nada mais é do que uma imensa rede de direitos e obrigações. É necessário um elemento juridico que confira a validade aos atos das partes. Esse elemento é a racionalidade do direito.

A realização do contrato forma um espaço racional, em que os homens podem se relacionar mediante a razao. Como é possível garantir que um poder absolutista garanta a proteção aos súditos uma vez que ele não pode ser julgado?

A existencia do contrato socal permite a formação de uma atmosfera de racionalidade. Por que o soberano agiria contra o individuo? como se afirmou, o comportamento, ainda que belicista, no estado de natureza é determinado por uma circuntacia a igualdade. Uma vez que o direito fornece para sempre um espaço social para que permitam a racionalidade. a obediência a diretriz estatal é sentida como obrigatória por circunstancias especificas que dão a atmosfera racional para a identificação do juridico. Assim, o soberano não tinha razao para agir contra o súdito.

Após a discussão estabelecida acima, há pelo menos três respostas para a pergunta em torno do estabelecimento da autoridade e a fundação da sociedade civil. Nos termos estabelecidos, uma solução, na linha estabelecida por Bobbio e Skinner endossa o hobbismo, a solução radical em prol do poder absoluto.

Nessa opção, todo e qualquer conteúdo pode ser direito uma vez que é emanado da autoridade. A escolha está fundada na razão segundo a qual toda e qualquer sociedade é melhor que o estado de natureza. A percepção dessa situação é a possibilidade do homem 
identificar a lei natural, sendo a mais importante e fundamental a lei de autopreservaçao. Em torno dessa opção, o ser humano se submeteria aos ditames de um poder sem limitação.

Nesse primeiro esquema, a ideia é que todo e qualquer soberano tem legitimidade, não existindo diferença entre soberania de fato e soberania de direito. Endossa-se o decisionismo acentuado, um tipo de positivismo. No esquema absolutista, o individuo do estado de natureza, detentor de plena liberdade e igualdade, torna-se súdito. A ideia de súdito resulta no esquema de que o soberano tem o direito de comandar e o súdito o dever de obedecer $^{179}$

Há uma modulação a fazer nesse esquema. Embora Skinner tenha denominado a sua visão como hobbista, ela é ligeiramente diferente da exposição que apresentei no inicio desse capitulo a qual denominei de hobbismo. Este chama a atenção por dois pontos. O primeiro é que afirma ser Hobbes um precursor do modelo imperativista do direito, definindo o direito como ordens baseadas em coerção. O segundo endossa a tese do pessimismo antropológico. $\mathrm{O}$ grande problema do hobbismo é que ele não é capaz de explicar o fenômeno juridico, o fundamento da obrigação. Há diferença entre absolutismo e autoritarismo que é justamente a ideia de legitimação racional da autoridade.

É importante frisar que a explicação de Skinner torna possível a correlaçoo desse esquema com o positivismo ideológico.

O segundo esquema é o que chamei de legalidade ou de estado de direito. Segundo essa interpretação, a instauração do contrato é feito mesmo pelo desejo de paz. O homem percebe a sua situação de miséria e é razoável supor que ele queira sair dessa situação. Instaura-se o contrato que funda a política no juridico, dando-lhe estabilidade. Isso significa que o ser humano está obrigado a obedecer as diretrizes da autoridade independentemente do conteúdo, uma vez que o comando é legitimo pois fundado no contrato. A autoridade tem o poder de comandar e o direito de comandar. O poder é que gera a situação a que chamo de legalidade, que é o espaço em que existe a possibilidade de relaoes racionais e formação de contratos validos. O contrato é valido se é voltado para um bem. Os homens não poderão fazer o contrato se não for lhe dado garantias de que esse contrato será cumprido. É aqui que entra o papel da coerção, que não é parte da definição do direito, mas aspecto material do Estado.

${ }^{179}$ RIBEIRO, Renato Janine. "Hobbes entre o medo e a esperança”, passim. 
Segundo essa visão, a de legalidade, toda a sociedade civil é permeada pelo direito. O direito funda a política e possibilita também a moralidade. Nesse espaço, o homem bom, aquele que age moralmente, tem plenas condições de efetivar as suas obrigações. Nesse sentido, a autoridade aparece para esse homem como um aspecto moral. Nessa atmosfera legal, o uso da força é justificada, uma vez que é em beneficio da coletividade. Maria Isabel limongi avança no seu arguento e afirma que na sociedade civil, ao contrario do esquema de Bobbio, as leis naturais geram obrigação em sentido próprio., o que abre espaço para a existencia da moral. Pode se apontar que é o desejo de paz que fundamenta a escolha pela heteronomia, porem não há a passagem para qualquer sociedade. A atmosfera obrigacional vigente impede que o soberano aja como um tirano e que os indivíduos realizem contratos inválidos, pois não existira circunstancias que gerassem razoes para isso. Essa leitura parece estar em sintonia com a ambiguidade notada em autores como Joseph Raz, que nega a conexão necessária entre direito e moral e ao mesmo tempo afirma a legitimidade moral da autoridade. Embora Limongi saliente que a obrigatoriedade é derivada do contrato, o que dá ao sua interpretação um aspecto de autorreferencialidade, no tocante à razão pratica, se observa uma adesão à autoridade, como o exemplo do homem bom tentou mostrar.

A terceira visão é aquela que endossa a tese jusnaturalista. Como se viu, Bobbio vê a lei natural como um trampolim para a sociedade civil. Assim como Skinner, Bobbio afirma que a lei natural não é uma lei obrigatória mas como máximas de prudência que permitem justificar racionalmente a adesão para o pacto de submissão a um poder ilimitado. A lei natural é uma escada que se utiliza para pular o muro e depois é descartada. Isso significa que não existe lei natural na sociedade civil. A leitura bobbiana de Hobbes afirma que a lei natural mata a lei natural: na sociedade civil somente existe um direito. a lei natural ordena a obediência a lei civil e à desobediência à lei natural. A visão jusnaturalista, defendida por autores como Warrender, Thammy Pogrebenschi e Perez zagorin defende um papel ativo da lei natural após o estabelecimento da socieade. A lei natural não mata a lei natural.

A partir da leitura dessa corrente, é possível antever tambem certa ambiguidade no papel da lei natural, mas em sentido difernte do esquema de legalidade. Na trilha deixada por Bobbio, se a lei natural existe na sociedade civil o soberano é limitado. De fato, é possível afirmar que há uma apreciação de conteúdo das diretrizes do soberano, ainda que mínima. 
Conforme a descrição da teoria da autoridade dos positivistas contemporâneos, uma decisão emanada de autoridade fornece uma razao que exclui as outras que compunham o balanço de razoes individual. Se uma ordem a ser dada ultraja, humilha ou poe a vida do súdito em risco, encerra-se o dever de obediência. Em outras palavras, há limites para a diretiva que exclui as razoes. Haveria um choque entre a razao consistente na diretiva da autoridade e algumas razoes que se tornam intangíveis. Essas razoes são aquelas mesmas que se identificam com a autopreservação.

Como se observou, a obra Hobbesiana é inesgotável. Ela permite muitas leituras, mas nem todas endossáveis plenamente em seus textos. Uma delas particularmente, a denominada hobbismo, é particularmente indefensável pois alicerçada em entendiemnto equivocado de conceitos hobbesianos.

As demais são plenamente sustentáveis, embora algumas pareçam mais plausíveis do que outras.

Sem duvida, a obra hobbesiana tornou-se mais significativa e mais clara a partir das contribuições trazidas pelas discussões em torno do conceito de autoridade. Se o retorno a modernidade é um recurso utilíssimo para a elucidação ou clarifiaçao de problemas contemporâneos, a recíproca também é verdadeira.

O debate efetuado na modernidade tornou-se mais significativo com o enquadramento que hoje a teoria analítica do direito proporcionou. Nesse sentido é que afirmo a vantagem de certas leituras perante outras.

A obra de Hobbes, visando responder diretamente o problema fundamental da liberdade que se identifica com o esforço teórico de construção de novas bases da política e de justificação da autoridade, dialoga diretamente com o debate contemporâneo cujo tópico central é a elucidação e fundamentação da autoridade. 


\section{CONCLUSÃO}

Terminada a exposição dos contornos da teoria da obrigação de Thomas Hobbes, não se pretende toma-la como algo acabada. Como já se escreveu, este estudo carece ainda de amplo desenvolvimento que somente com a leitura e releitura da fortuna crítica hobbesiana à luz dos novos desenvolvimentos trazidos e produzidos pela teoria analítica do direito poderá se aproximar do seu estagio ideal.

Mais uma vez, reitero que não há nenhuma tentativa de produzir um estudo que venha propositadamente apresentar uma interpretação diferente das demais. Não se pretende alcançar legitimidade a partir do suposto choque em um publico mais amplo ou mesmo entre os especialistas que compartilham de uma visão mais tradicional da teoria hobbesiana.

Até porque, apesar da apreentação do que denominei hobbismo, como um modelo interpretativo do pensamento político hobbesiano, enquanto identificado com a teoria imperativista do direito (Hobbes seria um teórico do comando) e como teórico do absolutismo, é realmente difícil encontrar uma convergência de visões: um comentador pode elaborar uma visão que traga tantos pontos comuns quanto discordantes de outro, além disso, mesmo quando utilizam um determinado termo, como, por exemplo, comando ou autoridade, o fazem com sentidos diferentes.

Realmente o texto de Hobbes possui pontos de grande ambivalência e elaborações de alto impacto (e que por isso cravam na memória) que parecem se chocar radicalmente com outros trechos encontrados no mesmo livro ou no restante de sua obra.

Nesse sentido, é realmente o caso de se falar no "problema da interpretação"180, título de um instigante ensaio de .... em que se tenta enfrentar o problema desenvolvendo três matrizes de leitura em Hobbes.

O que parece indubitável é a atualidade de seu pensamento. O Leviatã, e demais obras, fornecem um modelo inestimável e inesgotável para se refletir os problemas contemporâneos, relações que podem ser feitas de diferentes modos e níveis.

Hobbes, como se tentou mostrar, afirma a confiança de que o homem é capaz de superar certos problemas básicos advindos de circunstancias específicas. Ainda que o ser humano seja capaz de encontrar, pela razão o Certo, o Correto, diante de certas circunstancias,

${ }^{180}$ Citar o livro 
principalmente aquelas que constituem o que ele chamou de estado de natureza, não é possível a sua plena realização.

Somente a superação da guerra generalizada, ou seja, da tendência que promove a geração de conflitos o homem pode concretizar relações racionais, possibilitando assim a solução dos conflitos e a vida harmoniosa.

A condição para o estabelecimento da sociedade é o direito. O direito tem papel fundamental não somente para o próprio estabelecimento de agrupamentos com características peculiares, em que a guerra deixe de ser uma ameça, , como papel operativo na dinâmica interna nesta sociedade.

O direito funda a autoridade e permite entender os atos desta como eminentemente jurídicos.

A autoridade tem papel fundamental de criar regras que regulem a vida dos indivíduos, que a partir de então poderão se relacionar harmoniosamente, ou seja, se implementará a tendência da harmonia, em que os homens podem agir livremente no sentido da cooperação.

A grande atualidade do pensamenot de Hobbes é que ele traça um conceito de direito que coloca o problema da autoridade como chave fundamental. Em outras palavras, o entendimento do direito passa pela definição do conceito de autoridade, provocando a reflexão, necessária para a vida social, das razões de obediência, isto é, das razões que levam os indivíduos a obedecer e a desobedecer aquele poder comum fundado no direito.

A teoria hobbesiana do direito promove uma verdadeira gramática da obediência, no sentido de que as regras exercem papel fundamental na constituição de sentido dos atos de poder. A vida em sociedade ocorre em atmosfera racional, sendo que o direito à vida assume papel estruturante na cartilha de poderes individuais.

Ao contrario do que é apregoado, Hobbes não defende total submissão aos atos de poder e sim ao direito. $\mathrm{O}$ direito não é e não pode ser mera expressão da força. $\mathrm{O}$ direito não passa pela coerção e sim pela razão.

Nesse sentido, é possível identificar quando se está diante do direito e quando o individuo deve obediência, ainda que o comando seja fruto da vontade do soberano. Nem toda vontade é juridica. O direito que grassa na sociedade encontra-se com a lei natural, que encontra na sociedade a possibilidade plena de realização. É essa lei natural que irá permitir 
ao homem o entendimento do direito e a percepção se o comando que influencia o seu comportamento é juridico ou não.

Não havendo a razao que fundamenta a obrigação e que fundamenta a troca da heteronomia pela autonomia não existe o direito. Não há dever de obediência. O comando é pura expressão da força.

As leis naturais não são meras máximas prudenciais, mas preceitos morais percebidos com a razao e efetiváveis na sociedade politica. O direito positivo traz insito a lei natural que exerce um papel operacional na sociedade

o direito não é mero produto da vontade pois para ser valido precisa alcançar um bem. O soberano, embora não tenha limitações de poder, tem limitações cognitivas dadas pela lei natural e pelo bem que se quer atingir

Então existe uma leitura consistente de Hobbes que enfatiza a sua preocupação com a justificação racional da constituição da sociedade civil e que traz como consequência ligação do fundamento de obrigação do direto com a perquirição sobre a capacidade da ordem constituída em inclinar a sociedade para o bem. Nessa medida o conteúdo moral da ordem importa e há algum limite para a imoralidade do direito.

Como se observou, há leituras que endossam a ideia de jusnaturalismo como componente operacional no interior das socieades políticas. Há aquelas que apostam na legalidade da estrutura juridico-politica, capaz de criar uma atmosfera racional que permite o direito e o respeito pela autoridade. Nessa visão, não há risco para a ação tirânica porque não há circunstancias que gerem razoes que determinem tal comportamento no soberano, lembrando que a sua finalidade é a proteção dos súditos. Nesse sentido, as próprias definições advindas do contrato e da razoabilidade que motivou os homens a saírem do estado de natureza retiraria o elemento juridico do ato ofensivo do soberano. Nesse momento, então, hão há direito e o súdito está desobrigado.

Há leituras que incrementam o papel da lei natural na sociedade civil. É ela que permitirá uma apreciação de conteúdo das diretrizes do soberano. Nesse sentido, é apropriado se falar em soberania limitada.

O liame que tentou se estabelecer entre o debate da modernidade, que identifica no pensamento hobbesiano um paradigma, e o fecundo e complexo debate contemporâneo, polarizado entre interpretativistas e positivistas é com relação ao conceito de autoridade. 
Qual a justificativa racional para a substituição da autonomia pela heteronomia? Essa pergunta ilustra de forma destacada a presença de um problema que acompanha o desenvolvimento das sociedades complexas desde o século XVII.

Ao se invocar uma das leituras sobre a obra hobbesiana, em que se aponta a limitação da autoridade pela lei natural, em que medida esse limite não se aplica também aos positivistas contemporâneos, quando admitem, como faz Raz que a autoridade do direito, pressuposto da possibilidade de um sistema jurídico, tem necessariamente a pretensão de legitimidade moral? Essa pergunta será deixada para depois. 


\section{REFERÊNCIAS}

ANGOULVENT, Anne-Laure. Hobbes e a moral política. Papirus, 1996.

AUSTIN, John. The province of jurisprudence determined. Edited by Wilfrid E. Rumble. New York: Cambridge University Press, 1995.

BARRETO, Vicente de Paula (Coord. Científico). Dicionário de filosofia do direito. São Leopoldo: Ed. Unisinos; Rio de Janeiro: Renovar, 2006.

BOBBIO, Norberto. Thomas Hobbes and the natural law tradition. Chicago: Chicago University Press, 1993.

BOBBIO, Norberto. Thomas Hobbes. Rio de Janeiro: Campus, 1991.

BRONOWSKI, S; MAZLISH, Bruce. A tradição intelectual do Ocidente. Trad. Joaquim João Braga Coelho Rosa. Lisboa: Ediçoes 70, 1960.

BROWN, K. C. (Ed.). Hobbes: studies. Oxford: Blackwell, 1965.

BUNNIN, Nicholas; TSUI-JAMES, Eric. (Eds.). The Blackwell companion to philosophy. $2^{\text {nd }}$ ed. Wiley-Blackwel, 2002.

BURNS, Edward Mcnall. História da civilização ocidental. Trad. de Lourival Gomes Machado, Lourdes Santos Machado. Rio de Janeiro: Ed. Globo, 1948.

CALVINO, Ítalo. Por que ler os clássicos. São Paulo: Companhia das Letras, 1993.

CHAUÍ, Marilena. Introdução à historia da filosofia: dos pré-socráticos a Aristóteles. 2. ed. São Paulo: Companhia das Letras, 2007.

CURRAN, Eleanor. Hobbes's theory of rights - a modern interest theory. The Journal of Ethics, v. 6, p. 63-86, 2002.

DALLARI, Dalmo de Abreu. Elementos de teoria geral do Estado. 31. ed. São Paulo: Saraiva, 2012.

FERRAZ JR, Tércio Sampaio. A ciência do direito. 2. ed. São Paulo: Atlas, 2008.

FERRAZ JR, Tércio Sampaio. Introdução ao estudo do direito: técnica, decisão, dominação. 6. ed. São Paulo: Atlas, 2010.

GAUTHIER, David. Hobbes: the laws of nature. Pacific Philosophical Quarterly, v. 82, p 258-284, 2001.

GAUTHIER, David. Thomas Hobbes: moral theorist. The Journal of Philosophy, v. 76, n. 10, p. 547-559, Oct. 1979.

GERT, Bernard. The law of nature as the moral law. Hobbes Studies, Vol. I, 1988, pp. 26-44. 
GRINOVER, Ada Pellegrini; CINTRA, Antonio Carlos de Araújo; DINAMARCO, Candido Rangel. Teoria geral do processo. 28. ed. São Paulo: Malheiros Ed., 2012.

HART, Herbert. O conceito de direito. Lisboa: Fundação Calouste Gulbenkian, 1994.

HARVEY, Martin T. Hobbes's voluntarist theory of morals. Hobbes Studies, v. 22, n. 1, p. 49-69, 2009.

HERBERT, Gary. Fear of death and the foundations of natural right in the philosophy of Thomas Hobbes. Hobbes Studies, v. 7, n. 1, p. 56-58, 1994.

HOBBES, Thomas. Behemoth. Trad. de Eunice Ostrensky. Belo Horizonte: Ed. da UFMG, 2001.

HOBBES, Thomas. Behemoth or the Long Parliament,. London: Frank cass, 1969

HOBBES, Thomas. Diálogo entre um filósofo e um jurista. São Paulo: Landy, 2004.

HOBBES, Thomas. Do cidadão. São Paulo: Martins Fontes, 1998.

HOBBES, Thomas. Elementos do direito natural e político. Trad. Fernando Couto. Porto: Rés, 1993.

HOBBES, Thomas. Leviatã ou matéria, forma e poder de um estado eclesiástico e civil. Tradução de João Paulo Monteiro e Maria Beatriz Nizza da Silva. São Paulo: Martins Fontes, 2004.

HOBBES, Thomas. Leviatã ou Matéria, forma e poder de um estado eclesiástico e civil. Tradução de João Paulo Monteiro e Maria Beatriz Nizza Silva. 2. ed. São Paulo : Abril Cultural, 1979. (Os pensadores)

HOBBES, Thomas. Leviatã. São Paulo: Martins Fontes, 2005.

HOBBES, Thomas. Leviatã. Tradução de João Paulo Monteiro, Maria Beatriz Nizza Silva e Cláudia Belinger. Rev. Téc. Eunice Ostrensky. 1. ed. São Paulo: Martins Fontes, 2003.

HOBBES, Thomas. Leviathan. Ed. Michael Oakeshott. Introd. Richard S. Peters. Reprint edition. Touchstone; 2008.

HOBBES, Thomas. Leviathan. Edited by Richard Tuck. Cambridge; New York: Cambridge University Press, 1996.

HOBBES, Thomas. Os elementos de lei natural e política. Introd. J. C. A. Gaskin. Trad. Bruno Simões. Rev. da trad. Aníbal Mari. São Paulo: WMF Martins Fontes, 2010.

HOBBES, Thomas. Um diálogo entre um filósofo e um jurista. Trad. de Maria Cristina Guimarães Cupertino. São Paulo: Landy, 2001.

KAVKA, Gregory S. Hobbes's war of all against all. Ethics, v. 93, n. 2, p. 291-310, Jan. 1983. 
KAVKA, Gregory S. Hobbesian moral and political theory. New Jersey: Princeton University Press, 1986.

KEEGAN, John. Uma história da guerra. Tradução Pedro Maia Soares.São Paulo: Companhia das Letras, 1993.

KELSEN, Hans. O problema da Justiça. Tradução de João Baptista. Machado. 3. ed. São Paulo: Martins Fontes, 1998.

KELSEN, Hans. O que é justiça? Trad. Luiz Carlos Borges. São Paulo: Martins Fontes, 1997.

KELSEN, Hans. Teoria geral do direito e do Estado. Trad. Luís Carlos Borges. São Paulo: Martins Fontes, 2000.

KELSEN, Hans. Teoria pura do direito. Tradução João Baptista Machado. São Paulo: Martins Fontes, 2003.

LEBRUN, Gerard. O que é poder. São Paulo: Brasiliense, 1982.

LIMONGI, Maria Izabel. Hobbes. Rio de Janeiro: Jorge Zahar, 2002.

LOPES, José Reinaldo de Lima. O direito na história: lições introdutórias. 2.ed. rev. São Paulo: Max Limonad, 2002.

MACEDO, Paulo Emílio Vauthier Borges de. Hugo Grocio e o direito: o jurista da Guerra e da Paz. Rio de Janeiro, Lumen Juris, 2006.

MACPHERSON, C. B. A teoria política do individualismo possessivo: de Hobbes a Locke. Rio de Janeiro: Paz e Terra, 1979.

MAY, Larry. Hobbes on fidelity to law. Hobbes Studies, v. 5, p. 77-89, 1992.

NUNAN, Richard. Hobbes on morality, rationality and foolishness. Hobbes Studies, v. 2, p. 40-64, 1989.

OAKESHOT, Michael. An introduction to Thomas Hobbes's Leviathan; the matter, form and power of a commonwealth: ecclesiastical and civil. Oxford: Basil Blackwell, 1946.

PANICHAS, George E. Hobbes, prudence and basic rights. Noûs, v. 22, n. 4, p. 555-571, Dec. 1988.

POGREBINSCHI, Thamy. Hobbes, Thomas 1588-1679. In: BARRETO, Vicente de Paula (Coord. Científico). Dicionário de filosofia do direito. São Leopoldo: Ed. Unisinos; Rio de Janeiro: Renovar, 2006.

POGREBINSCHI, Thamy. Problema da obediência em Thomas Hobbes. São Paulo: EDUSC, 2003.

REALE, Miguel. Lições preliminares. 27. ed. São Paulo: Saraiva, 2004. 
RIBEIRO, Renato Janine. A marca do Leviatã: linguagem e poder em Hobbes. São Paulo: Ática, 1978.

RIBEIRO, Renato Janine. Ao leitor sem medo: Hobbes escrevendo contra o seu tempo. Belo Horizonte: Ed. UFMG, 1999.

RIBEIRO, Renato Janine. Hobbes, Thomas (1588-1679). In: BARRETO, Vicente de Paula (Coord. Científico). Dicionário de filosofia do direito. São Leopoldo: Ed. Unisinos; Rio de Janeiro: Renovar, 2006. RIBEIRO, Renato Janine. Hobbes: o medo e a esperança. In: WEFFORT, Francisco C. (Org.). Os classicos da política: Maquiavel, Hobbes, Locke, Montesquieu, Rousseau, "O Federalista". 13. ed. São Paulo: Ática, 2004. v. 1.

SADEK, Maria Tereza. Nicolau Maquiavel: o cidadão sem fortuna, o intelectual de virtù. In: WEFFORT, Francisco C. (Org.). Os classicos da política: Maquiavel, Hobbes, Locke, Montesquieu, Rousseau, "O Federalista". 13. ed. São Paulo: Ática, 2004. v. 1.

SHAPIRO, Scott J. Authority. In: COLEMAN, Jules; SHAPIRO, Scott J. (Eds.). The Oxford handbook of jurisprudence and philosophy of law. New York: Oxford University Press, 2002. p. 382-439.

SILVA, Franklin Leopoldo e. Descartes e o discurso da modernidade. São Paulo: Ática, 1999.

SKINNER, Quentin. As fundações do pensamento político moderno. São Paulo: Companhia das Letras, 1996.

SKINNER, Quentin. Liberdade antes do liberalismo. São Paulo: Ed. da Unesp, 1999.

SKINNER, Quentin. Razão e retórica na filosofia de Hobbes. São Paulo: Ed. da Unesp, 1999.

SKINNER, Quentin.The proper signification of liberty.Cambridge: Cambridge University Press, 2006.

SORELL, Tom (Ed.). Hobbes. Tradução André Oides. São Paulo: Ideias \& Letras, 2011.

SORELL, Tom. Hobbes and the morality beyond justice. Pacific Philosophical Quarterly, v. 82, p 227-242, 2001.

SORELL, Tom. Hobbes. In: BUNNIN, Nicholas; TSUI-JAMES, Eric. (Eds.). The Blackwell companion to philosophy. $2^{\text {nd }}$ ed. Wiley-Blackwel, 2002.

SORELL, Tom. Introdução. In: (Ed.). Hobbes. Tradução André Oides. São Paulo: Ideias \& Letras, 2011.

SOUSA, José Pedro Galvão de; GARCIA, Clovis Lema; CARVALHO, José Fraga Teixeira de. Dicionário de política. São Paulo: T. A. Queiroz, 1998.

STRAUSS, Leo. Direito natural e história. Tradução Miguel Morgado. Lisboa: Ediçoes 70, 2009. 
TRANJAN, Tiago. Interpretando Galileu. Folha de S. Paulo, São Paulo, 14 jun. 2009. Caderno Mais!

TUCK, Richard. Hobbes and democracy. In: ANNABEL, Brett; TULLY, James; HAMILTON-BLEAKLEY, Holly (Eds.). Rethinking the foundations of modern political thought. New York: Cambridge University Press, 2006.

TUCK, Richard. Hobbes. Trad. Adail Ubirajara, Mara Stela Gonçalves. São Paulo: Ediçoes Loyola, 2001.

TUCK, Richard. Hobbes: a very short introduction. New York: Oxford University Press, 2002.

TUCK, Richard. The modern theory of natural law. In: PAGDEN, Anthony (Ed.). Languages of politics in early modern Europe. Cambridge: Cambridge University Press, 1969.

WARRENDER, Howard. The political philosophy of Hobbes: his theory of obligation. Oxford: Oxford University Press, 1957.

WEFFORT, Francisco C. (Org.). Os classicos da política: Maquiavel, Hobbes, Locke, Montesquieu, Rousseau, "O Federalista". 13. ed. São Paulo: Ática, 2004. v. 1.

ZAGORIN, Perez. Hobbes and the law of nature. United Kingdom: Princeton University Press, 2009. 